Review

\title{
Advection in polar and sub-polar environments: Impacts on high latitude marine ecosystems
}

\author{
George L. Hunt Jr. ${ }^{\mathrm{a}, *}$, Kenneth F. Drinkwater ${ }^{\mathrm{b}}$, Kevin Arrigo ${ }^{\mathrm{c}}$, Jørgen Berge ${ }^{\mathrm{d}}$, Kendra L. Daly ${ }^{\mathrm{e}}$, \\ Seth Danielson $^{\mathrm{f}}$, Malin Daase ${ }^{\mathrm{d}, \mathrm{g}}$, Haakon Hop ${ }^{\mathrm{d}, \mathrm{g}}$, Enrique Isla ${ }^{\mathrm{h}}$, Nina Karnovsky ${ }^{\mathrm{i}}$, Kristin Laidre ${ }^{\mathrm{a}, \mathrm{j}}$, \\ Franz J. Mueter ${ }^{\mathrm{e}}$, Eugene J. Murphy ${ }^{\mathrm{k}}$, Paul E. Renaud ${ }^{1}$, Walker O. Smith Jr. ${ }^{\mathrm{m}}$, Philip Trathan ${ }^{\mathrm{k}}$, John Turner $^{\mathrm{k}}$, \\ Dieter Wolf-Gladrow ${ }^{\text {n }}$
}

${ }^{a}$ School of Aquatic and Fishery Sciences, University of Washington, Seattle, WA 98195, USA

${ }^{\mathrm{b}}$ Institute of Marine Research, Box 1870 Nordnes, N-5817 Bergen, Norway

${ }^{\mathrm{c}}$ Department of Earth System Science, Stanford University, Stanford, CA 94305, USA

${ }^{\mathrm{d}}$ Department of Arctic and Marine Biology, UIT The Arctic University of Norway, N-9037 Tromsø, Norway

e College of Marine Science, University of South Florida, St. Petersburg, FL 33620, USA

${ }^{\mathrm{f}}$ School of Fisheries and Ocean Sciences, University of Alaska Fairbanks, Fairbanks, AK 99775, USA

${ }^{\mathrm{g}}$ Norwegian Polar Institute, Fram Centre, N-9296 Tromsø, Norway

${ }^{\mathrm{h}}$ Institut de Ciències del Mar-CSIC, Passeig Marítim de la Barceloneta 37-49, Barcelona 08003, Spain

i Pomona College, Department of Biology, Claremont, CA 91711, USA

${ }^{\mathrm{j}}$ Polar Science Center, Applied Physics Laboratory, University of Washington, Seattle, WA 98105, USA

${ }^{\mathrm{k}}$ British Antarctic Survey, High Cross, Madingley Road, Cambridge CB3 OET, United Kingdom

${ }^{1}$ Akvaplan-niva, Fram Centre, N-9296 Tromsø, Norway

${ }^{\mathrm{m}}$ Virginia Institute of Marine Science, College of William \& Mary, Gloucester Point, VA 23062, USA

${ }^{\mathrm{n}}$ Alfred Wegener Institute, Helmholtz Centre for Polar and Marine Research, D-27515 Bremerhaven, Germany

\section{A R T I C L E I N F O}

\section{Article history:}

Received 14 June 2015

Received in revised form 29 September

2016

Accepted 5 October 2016

Available online 14 October 2016

\section{Keywords:}

Advection

Climate change

Polar and sub-polar biota

Polar marine ecosystems

Sea ice

\section{A B S T R A C T}

We compare and contrast the ecological impacts of atmospheric and oceanic circulation patterns on polar and sub-polar marine ecosystems. Circulation patterns differ strikingly between the north and south. Meridional circulation in the north provides connections between the sub-Arctic and Arctic despite the presence of encircling continental landmasses, whereas annular circulation patterns in the south tend to isolate Antarctic surface waters from those in the north. These differences influence fundamental aspects of the polar ecosystems from the amount, thickness and duration of sea ice, to the types of organisms, and the ecology of zooplankton, fish, seabirds and marine mammals. Meridional flows in both the North Pacific and the North Atlantic oceans transport heat, nutrients, and plankton northward into the Chukchi Sea, the Barents Sea, and the seas off the west coast of Greenland. In the North Atlantic, the advected heat warms the waters of the southern Barents Sea and, with advected nutrients and plankton, supports immense biomasses of fish, seabirds and marine mammals. On the Pacific side of the Arctic, cold waters flowing northward across the northern Bering and Chukchi seas during winter and spring limit the ability of boreal fish species to take advantage of high seasonal production there. Southward flow of cold Arctic waters into sub-Arctic regions of the North Atlantic occurs mainly through Fram Strait with less through the Barents Sea and the Canadian Archipelago. In the Pacific, the transport of Arctic waters and plankton southward through Bering Strait is minimal.

In the Southern Ocean, the Antarctic Circumpolar Current and its associated fronts are barriers to the southward dispersal of plankton and pelagic fishes from sub-Antarctic waters, with the consequent evolution of Antarctic zooplankton and fish species largely occurring in isolation from those to the north. The Antarctic Circumpolar Current also disperses biota throughout the Southern Ocean, and as a result, the biota tends to be similar within a given broad latitudinal band. South of the Southern Boundary of the ACC, there is a large-scale divergence that brings nutrient-rich water to the surface. This divergence, along with more localized upwelling regions and deep vertical convection in winter, generates elevated nutrient levels throughout the Antarctic at the end of austral winter. However, such elevated nutrient levels do not support elevated phytoplankton productivity through the entire Southern Ocean, as iron concentrations are rapidly removed to limiting levels by spring blooms in deep waters. However, coastal

\footnotetext{
* Corresponding author.

E-mail address: glhunt@uci.edu (G.L. Hunt Jr.).
} 
regions, with the upward mixing of iron, maintain greatly enhanced rates of production, especially in coastal polynyas. In these coastal areas, elevated primary production supports large biomasses of zooplankton, fish, seabirds, and mammals. As climate warming affects these advective processes and their heat content, there will likely be major changes in the distribution and abundance of polar biota, in particular the biota dependent on sea ice.

(c) 2016 Elsevier Ltd. All rights reserved.

\section{Contents}

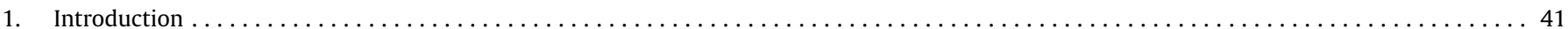

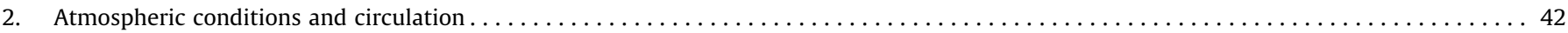

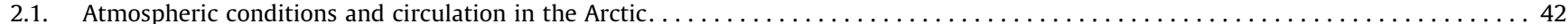

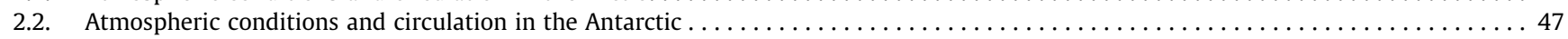

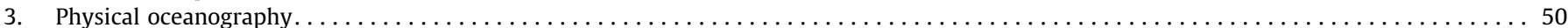

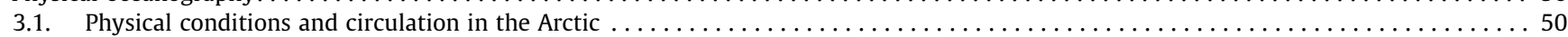

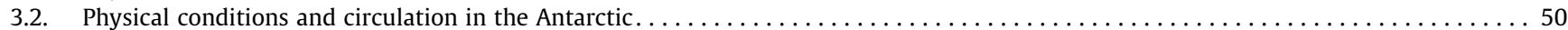

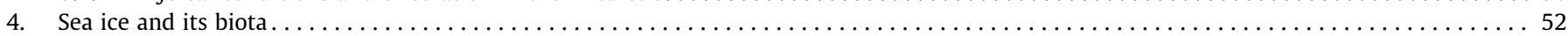

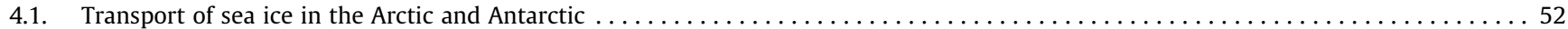

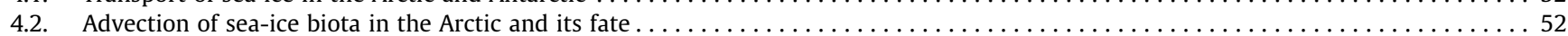

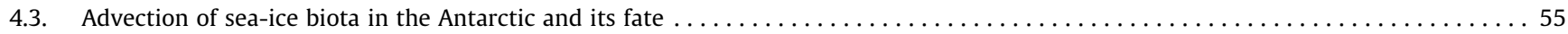

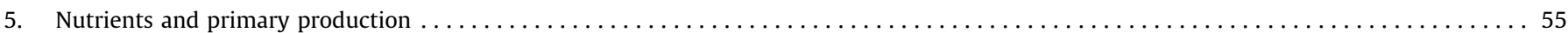

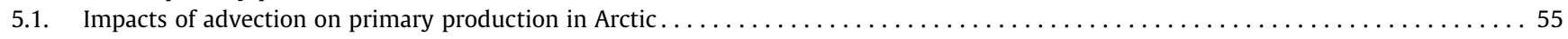

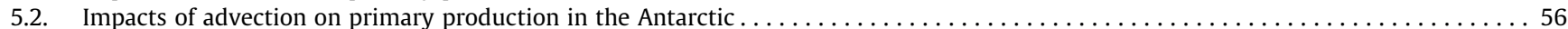

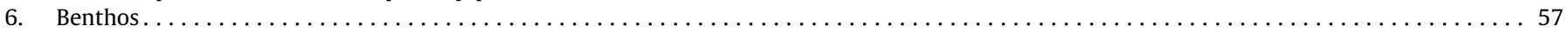

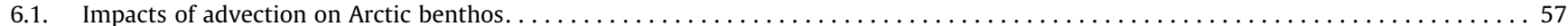

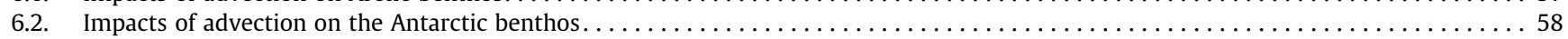

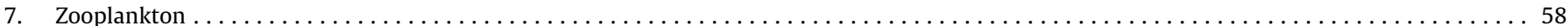

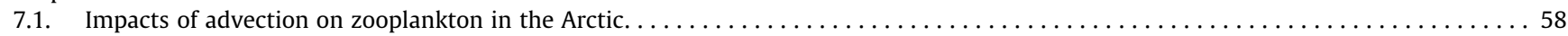

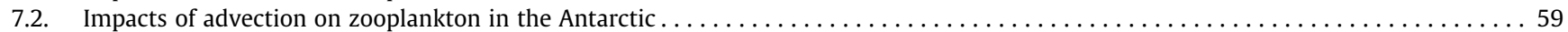

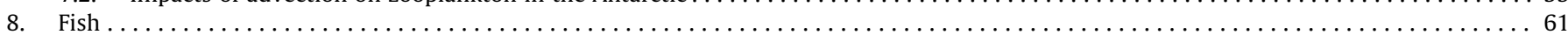

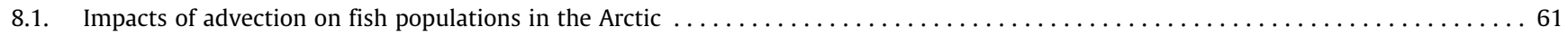

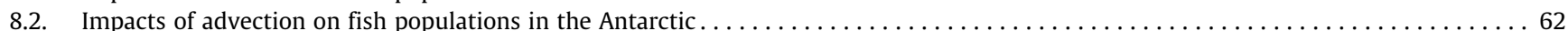

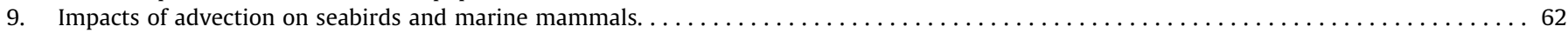

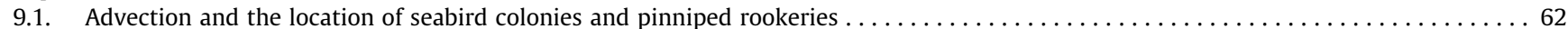

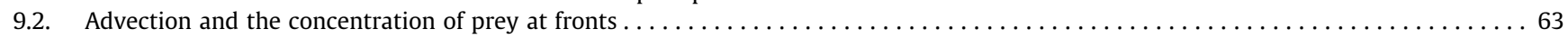

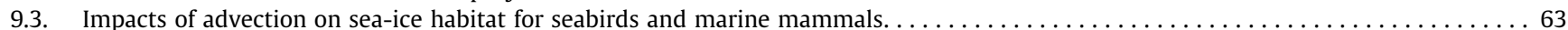

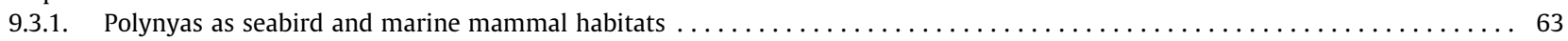

9.3.2. Melting of sea ice and the availability of open water to seabirds and marine mammals $\ldots \ldots \ldots \ldots \ldots \ldots \ldots \ldots \ldots \ldots \ldots \ldots$

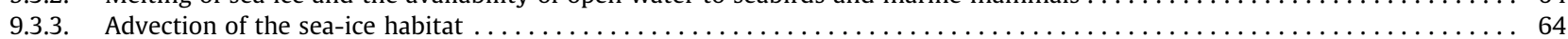

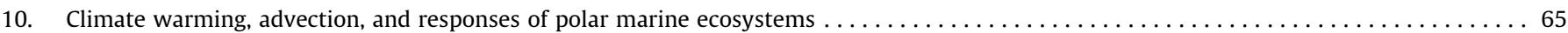

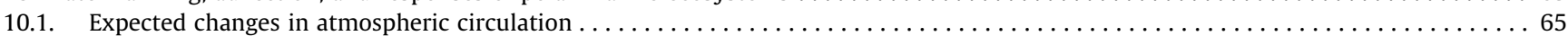

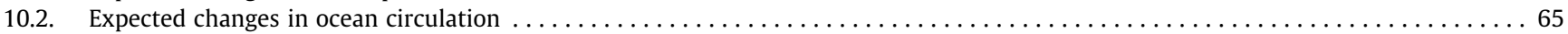

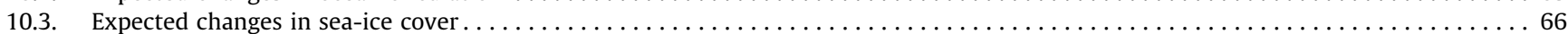

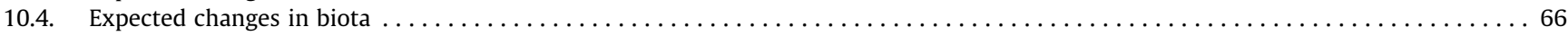

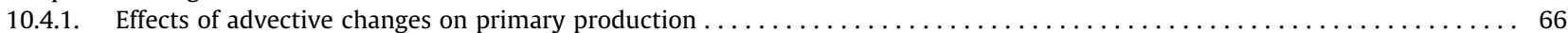

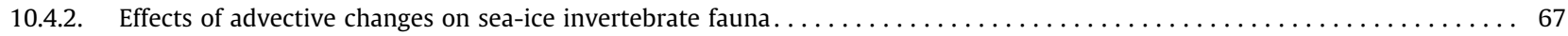

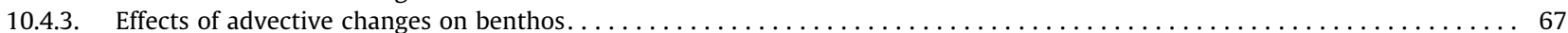

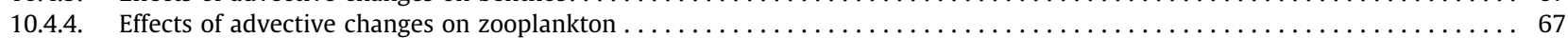

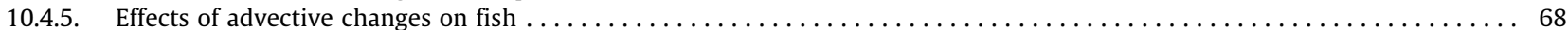

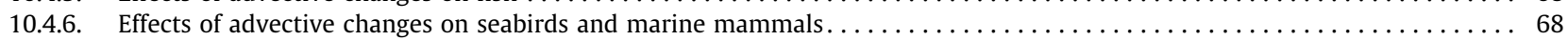

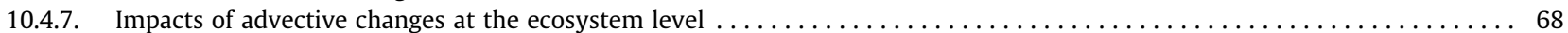

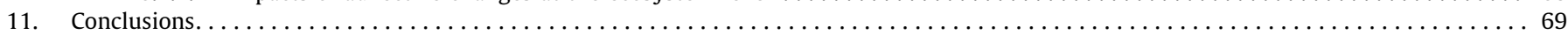

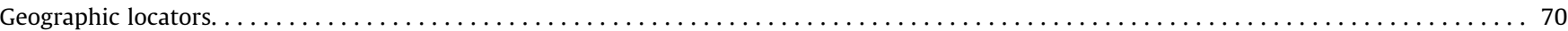

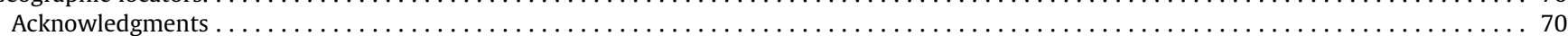

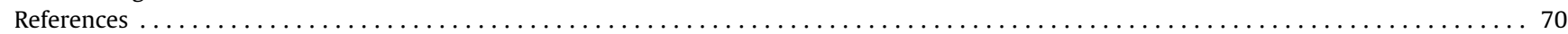

\section{Introduction}

Advective processes, in both the atmosphere and ocean, are critical for connecting polar marine ecosystems to those at lower latitudes. Atmospheric circulation carries heat from lower latitudes to polar regions, and helps drive the major high-latitude surface ocean currents. These currents transport nutrients and particulate carbon, in the form of detritus, phytoplankton, and zooplankton, between ecosystems. Spatial and temporal variability in these transports influence organisms at all trophic levels, from phyto- 
plankton to marine birds and mammals. In this review paper, we seek to highlight the different ways in which advective processes in the Northern and Southern Hemispheres affect their high latitude marine ecosystems, and how climate change may alter these systems.

Much can be learned from comparisons of aquatic biomes, especially since direct experimentation on large marine ecosystems is impossible. The comparative approach can provide insights into fundamental ecosystem processes and what might be unique to a particular ecosystem (Murawski et al., 2010). Such mechanistic information can also be used to understand and model other marine ecosystems where such comparisons have not been completed. Comparative studies have been successfully applied and have helped to understand the impacts of climate on marine ecosystems (e.g., Moline et al., 2008; Megrey et al., 2009; Barange et al., 2010; Mueter et al., 2012; Hunt et al., 2013). Many studies comparing the Arctic and Antarctic have been undertaken in the past, focusing on such topics as: climate change (Turner and Overland, 2009; Marshall et al., 2014), microbes (Bano et al., 2004), ice bacteria (Brinkmeyer et al., 2003), sea-ice algae and phytoplankton (Tremblay and Smith, 2007; Arrigo et al., 2010), foraminifera (Darling et al., 2000), fungi (Robinson, 2001), benthos (George, 1977; Starmans and Gutt, 2002; Zacher et al., 2009), zooplankton (Falk-Petersen et al., 2000; Deibel and Daly, 2007; Walkusz et al., 2004; McBride et al., 2014), fishes (Eastman, 1997; McBride et al., 2014) and seabirds (Hunt and Nettleship, 1988; Joiris, 2000). However, no comparative studies have focused on the role of advection, which can play a defining role in the structure and functioning of polar marine ecosystems. By looking at both polar systems, it was our intent that this paper would be useful as a means of increasing our understanding of connections within the systems by contrasting two superficially similar but very different systems.

Our geographic focus in the Arctic is the waters in the deep basins, which are separated by a series of ridge systems, and the surrounding continental shelves. We also address processes in the Bering Sea that modify Pacific Water flowing into the Arctic, and processes in the Canadian Archipelago, as large quantities of water from the Western Arctic Ocean flow southward through the straits of the Archipelago (Fig. 1). The Arctic Ocean is mostly surrounded by land; the only seawater exchange with the Pacific Ocean occurs through Bering Strait (Fig. 2), while exchanges with the Atlantic Ocean occur through Fram Strait, the Barents Sea, and the Canadian Archipelago (Figs. 1 and 3). The Arctic is greatly influenced by its broad, shallow (50-200 m) continental shelves that comprise approximately $50 \%$ of the Arctic Ocean area.

The Southern Ocean physically encompasses the region from the Antarctic continent north to the Subtropical Front, but here we mainly focus on the regions south of the Polar Front (Orsi et al., 1995). Bottom depths are typically 4000-5000 m, with relatively narrow but deep (50-800 m, mean $500 \mathrm{~m}$ ) continental shelf regions (Fig. 4). There are also deep shelves around the subAntarctic islands, such as at South Georgia and at the Kerguelen Plateau. The open Southern Ocean encircles the continent of Antarctica with waters of the Antarctic Circumpolar Current that mainly flow clockwise in latitudinal bands separated by frontal zones at which current speeds are elevated (Fig. 4). This current and its associated fronts limit lateral exchange between the Antarctic and sub-Antarctic surface waters, thereby tending to isolate the upper layers in Southern Ocean. South of the Antarctic Circumpolar Current, marked by the Southern Boundary of the Antarctic Circumpolar Current, the Antarctic Coastal Current, flows counterclockwise around the coastal region. Between the Southern Boundary of the Antarctic Circumpolar Current and coastal regions, there are major clockwise-flowing gyres in the embayment areas of the Ross and Weddell Seas. Dense waters, which form on the continental shelves through cooling and brine rejection, sink and flow away from the Southern Ocean at great depths, thereby playing a major role in the global thermohaline circulation (Sloyan and Rintoul, 2001). Wind-driven upwelling in the Southern Ocean is equally important to this global circulation as a return path from the interior ocean to the surface (Marshall and Speer, 2012).

Here we synthesize knowledge of the major polar ocean currents, and how these influence the marine ecosystems in both northern and southern regions. We begin with the major atmospheric circulation patterns (Section 2), examining how they impact the ocean circulation patterns at high latitudes and how these currents serve to influence polar oceans and their ecosystems (Section 3). We explore the meridional fluxes of heat, nutrients and plankton in the Northern Hemisphere, and how these help to support local primary and secondary production, as well as benthic biota, fish, and marine birds and mammals. For the Southern Hemisphere, we examine how the annular currents isolate the Southern Ocean from regions to the north and disperse organisms. Sections 4-9, respectively, focus on major ecosystem functional groups: sea ice and its associated biota, nutrients and phytoplankton, benthos, zooplankton, fish, and seabirds and marine mammals. In Section 10, we provide a discussion of how a warming climate may affect these advection patterns and consequently the marine ecosystems of the high latitudes. The final section (11) summarizes our findings.

\section{Atmospheric conditions and circulation}

The mean atmospheric conditions in the Arctic and Antarctic have some similarities: cold air temperatures, strongly seasonal light and heat input, relatively low precipitation, high sea-level pressure, and characteristic cyclonic wind patterns (counterclockwise in the Arctic, clockwise in the Antarctic). However, there are marked differences in the mean sea level pressure fields (Fig. 5), and therefore in the near-surface winds between the Arctic and Antarctic, which are a result of the differences in the topography and land-sea distributions between the two Polar Regions.

The mean sea level pressure in the Arctic is generally higher than in the Antarctic (Fig. 5), and the winds are weaker on average. In the Arctic, there is no comparable feature to the Antarctic circumpolar trough; rather the lowest mean sea level pressure values are found in the two main storm centers of the Iceland and Aleutian lows. While few significant lows penetrate into the high interior of the Arctic, low pressure systems travel from Iceland to north of Norway (Fig. 5a), indicating that, because of the topography, cyclones commonly enter the Arctic basin.

\subsection{Atmospheric conditions and circulation in the Arctic}

Atmospheric circulation plays an important role in the advection of heat between lower latitudes and the Arctic. Indeed, the mean meridional heat transport is predominantly atmospherically driven in the Northern Hemisphere, with a much smaller contribution by ocean currents (Trenberth and Caron, 2001; Serreze et al., 2007; Rhines et al., 2008). Rhines et al. (2008) point out, however, that as the air moves northward, it receives heat and moisture from the oceans through air-sea fluxes and thus, at least part of the meridional atmospheric transport is coupled with ocean heat transport.

Arctic air temperatures have increased at almost twice the global average over the last few decades (ACIA, 2005; IPCC, 2013). This phenomenon, termed Arctic amplification, is consistent throughout the region (Overland et al., 2004), and has been attributed to amplified ice-albedo feedbacks associated with reduced sea-ice extent, concentration, and thickness (Serreze and Francis, 2006; 

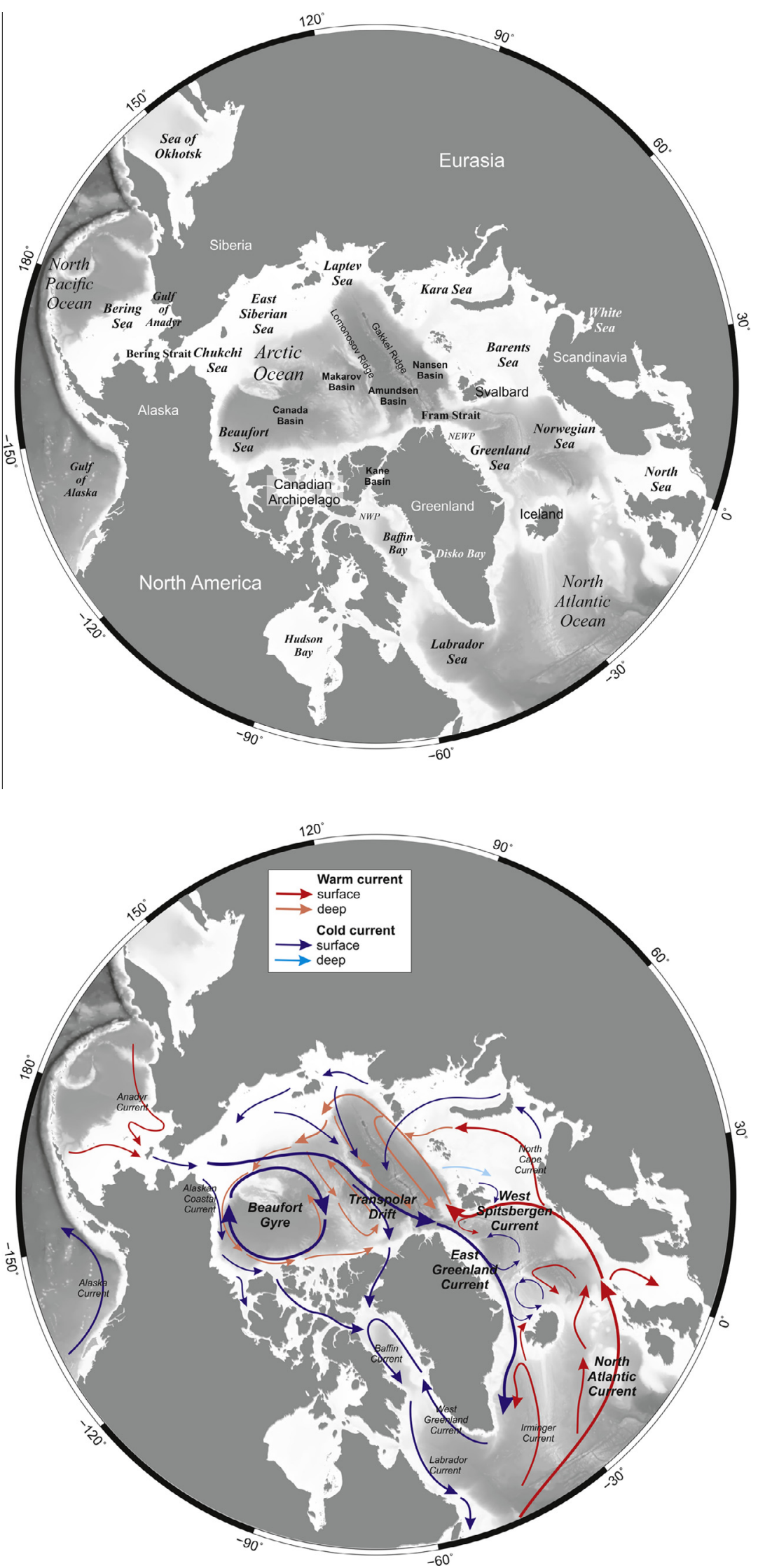

Fig. 1. Left: Place names in the Arctic and sub-Arctic referred to in the text; Right: Major currents and water masses in the Arctic and sub-Arctic. 


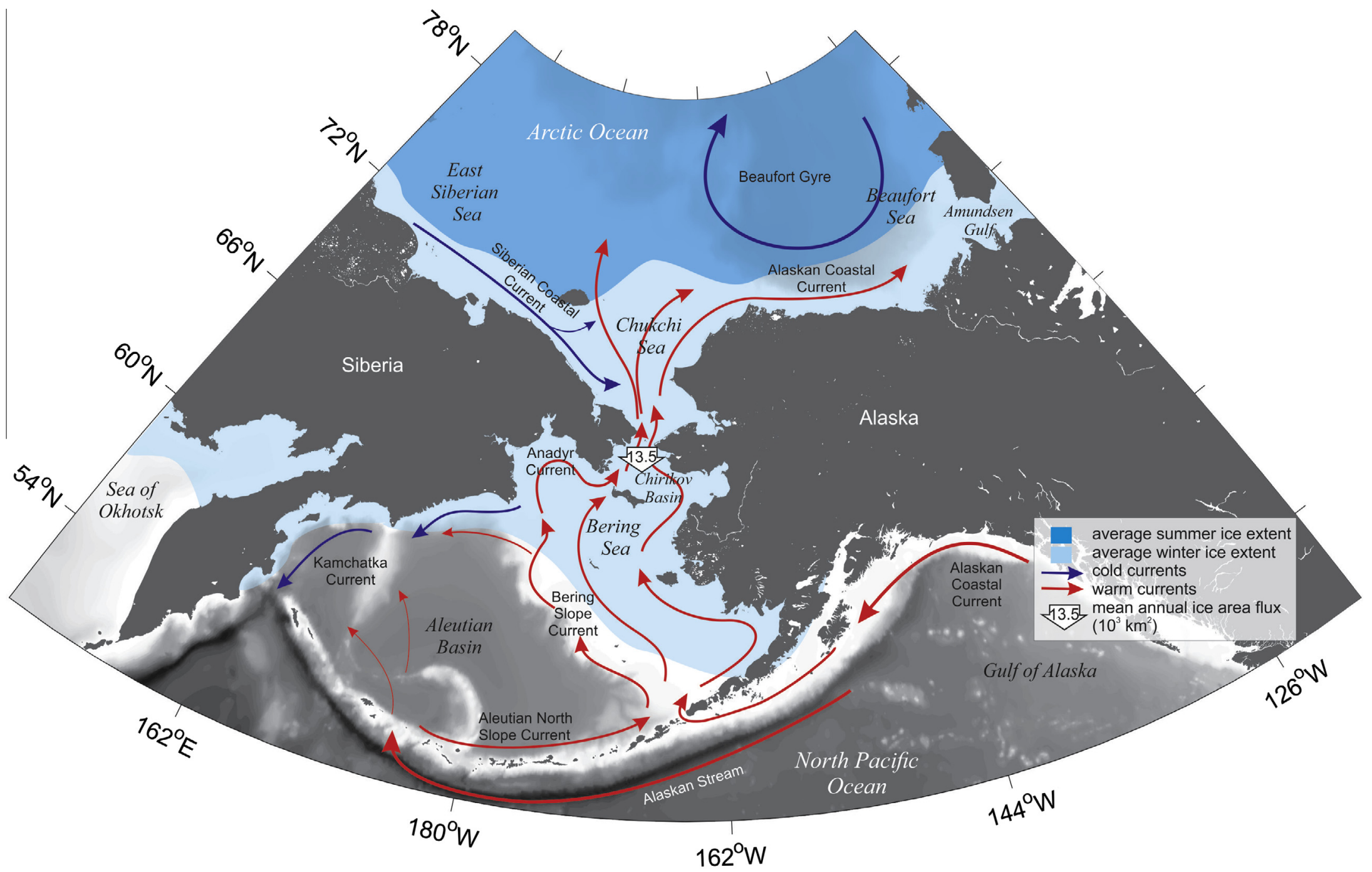

Fig. 2. Pacific Arctic, with details of water masses, currents and physical features referred to in the text. Mean annual ice flux from Woodgate and Aagaard (2005). 


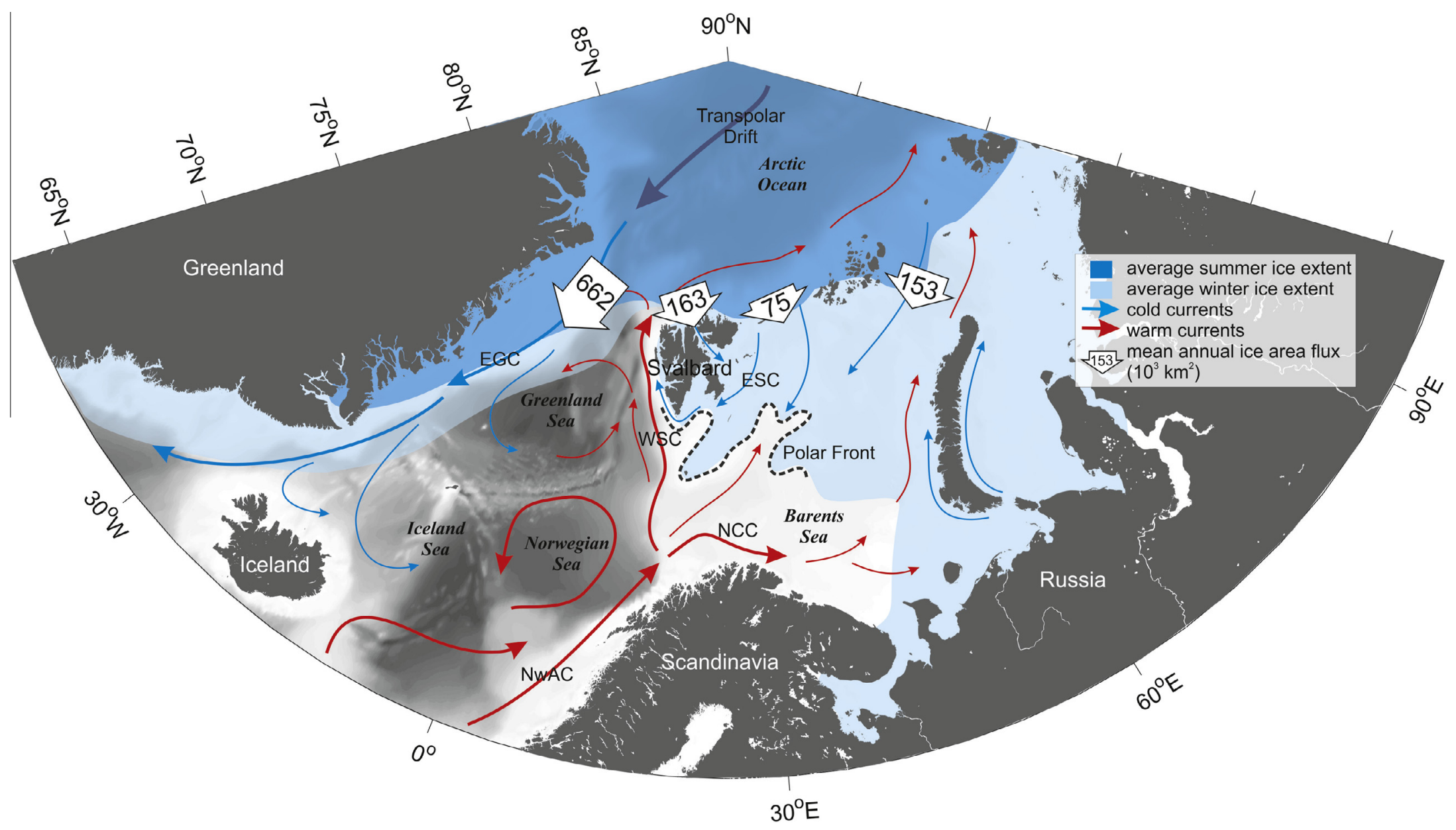

Fig. 3. Atlantic Arctic, with details of water masses, currents and physical features referred to in the text. Mean annual ice flux from Hop and Pavlova (2008). 

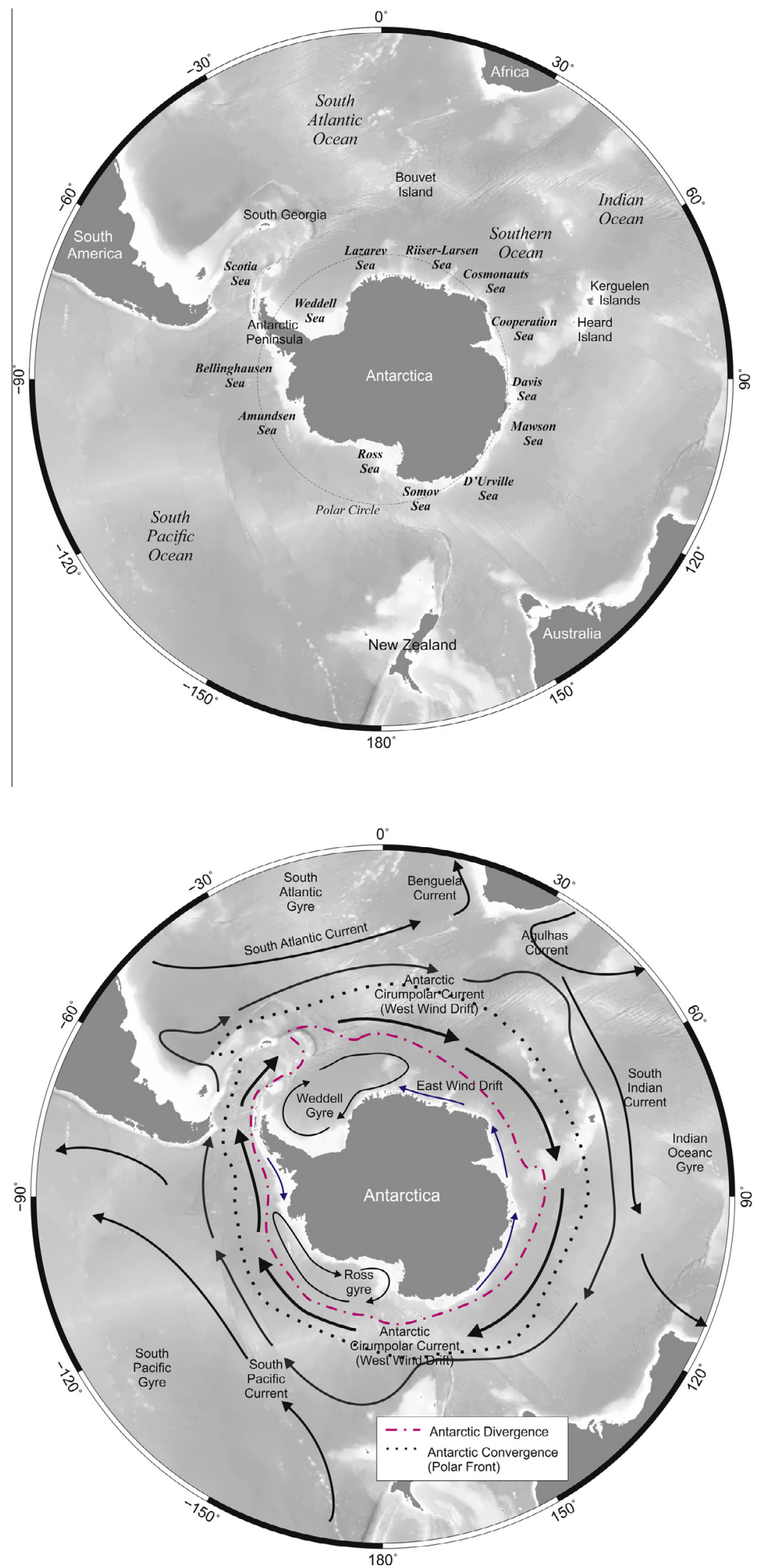

Fig. 4. Left: Place names in the Southern Ocean and sub-Antarctic referred to in the text; Right: Major currents and water masses in the Southern Ocean and sub-Antarctic. Note: the Ross, Scotia, and Weddell seas are defined by circulation, unique water mass characteristics and geomorphology; the other 'seas' surrounding the Antarctic continent are not so defined. 

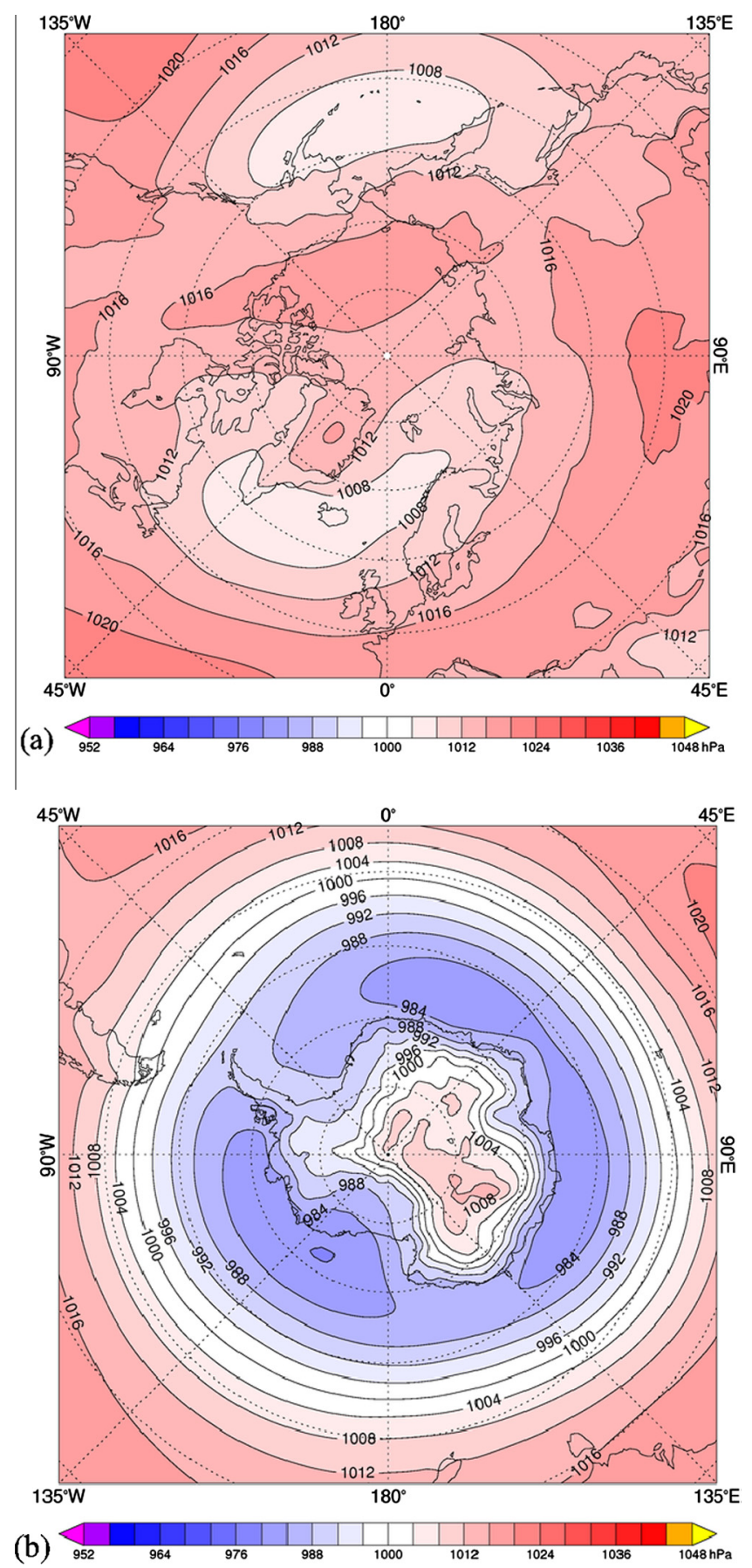

Fig. 5. The annual mean level pressure (MSLP) for 1979-2014. (a) The Arctic and (b) the Antarctic. Scaled by: 0.01 .

Screen et al., 2010; Screen and Simmonds, 2010; Walsh et al., 2011; Stroeve et al., 2012). However, Graversen et al. (2008) concluded that increases in the meridional atmospheric heat transport might also be playing a significant role in the Arctic amplification, noting that warming has occurred in the upper atmosphere over the Arctic well above where snow and ice feedbacks play a role.

Variability in Arctic air temperatures is closely linked to the large-scale atmospheric pressure patterns as expressed by the Arctic Oscillation, which is also known as the Northern Annular Mode (Fig. 6). This is the leading mode of winter sea-level-pressure variability over the Arctic and the Northern Hemisphere mid-latitudes. It represents a reorganization of mass between the high and mid- latitudes in the Northern Hemisphere that is associated with variability in the high over the central Arctic and the Aleutian and Iceland lows located over the North Pacific and North Atlantic, respectively (Thompson and Wallace, 1998). It is strongly correlated with the North Atlantic Oscillation.

The Arctic Polar Vortex is the intense cyclonic (counterclockwise) circulation that develops in winter in the midtroposphere between the very cold air to the north and milder air in mid-latitudes. High interannual variability in the strength and shape of this feature results in large uncertainties in its temporal trends (Solomon et al., 2007), which depend strongly on the time period over which analyses are conducted (Langematz and Kunze, 2008). During colder-than-normal periods in the Arctic, the vortex tends to become more symmetrical, and the anticlockwise winds surrounding the vortex strengthen. This acts to decrease the atmospheric connections between the Arctic and sub-Arctic regions. In contrast, during warming periods in the Arctic, the Arctic Polar Vortex tends to weaken (Fig. 6), allowing outbreaks of cold Arctic air masses to flow farther south over the continents, which can bring extreme cold and snow to regions normally not exposed to such conditions (Francis and Vavrus, 2012; Walsh, 2014). This advection of cold air linking the Arctic to the sub-Arctic and mid-latitude areas has been termed the "warm Arctic, cold continent" pattern (Overland et al., 2011).

Winds not only play important roles in the advection of atmospheric heat and moisture, but also drive ocean currents both into and out of the Arctic, thereby affecting oceanic fluxes of heat, salt, nutrients and biota. In the Pacific sector, frequent low-pressure systems (storms) exert strong control over the western Arctic and sub-Arctic through their influence on ocean circulation patterns, mixing and upwelling (Overland, 1986; Isoguchi et al., 1997; Pickart et al., 2009), and link the two regions through oceanic forcing. For example, these storms mediate flow variations in Bering Strait (e.g., Roach et al., 1995; Cherniawsky et al., 2005; Woodgate et al., 2005b; Danielson et al., 2014) and hence influence the variability of transport of nutrient-rich Pacific waters into the Arctic. Storms that move into the Gulf of Alaska tend to shift the climatological Aleutian Low eastward, reducing transport through Bering Strait over daily to weekly time scales, but cause increased transport anomalies over annual time scales (Danielson et al., 2014). The annual transport anomalies are associated with a changing Pacific-Arctic sea-level elevation difference that is caused in part by changes in Ekman suction over the deep North Pacific. In contrast, the shorter-time-scale (synoptic) anomalies are driven by local wind forcing and continental shelf waves that propagate into and through Bering Strait. Bering Strait flow reversals are common in winter, but generally persist for only a few days; multi-week reversals occur infrequently (Coachman and Aagaard, 1981; Woodgate et al., 2005a, 2005b).

Winds and pressure systems influence other oceanic flows between the Arctic and sub-Arctic. For example, the Ekman response to northeastward winds in the Canadian Beaufort Sea produces higher sea level elevations along the coast of this Arctic region. This results in a sea level elevation gradient across the Canadian Arctic Archipelago that drives flow from the Arctic towards Baffin Bay (Peterson et al., 2012). In the Northeast Atlantic, Ingvaldsen (2005) noted that stronger southwesterly winds produce higher velocities and greater Atlantic inflow from the SubArctic into the Barents Sea. Lien et al. (2013) recently showed covariability of this current with the flow into Fram Strait in response to Ekman transport off the northern Barents Sea shelf.

\subsection{Atmospheric conditions and circulation in the Antarctic}

Atmospheric conditions over the Southern Ocean are strongly influenced by lower latitude processes, especially in the South 

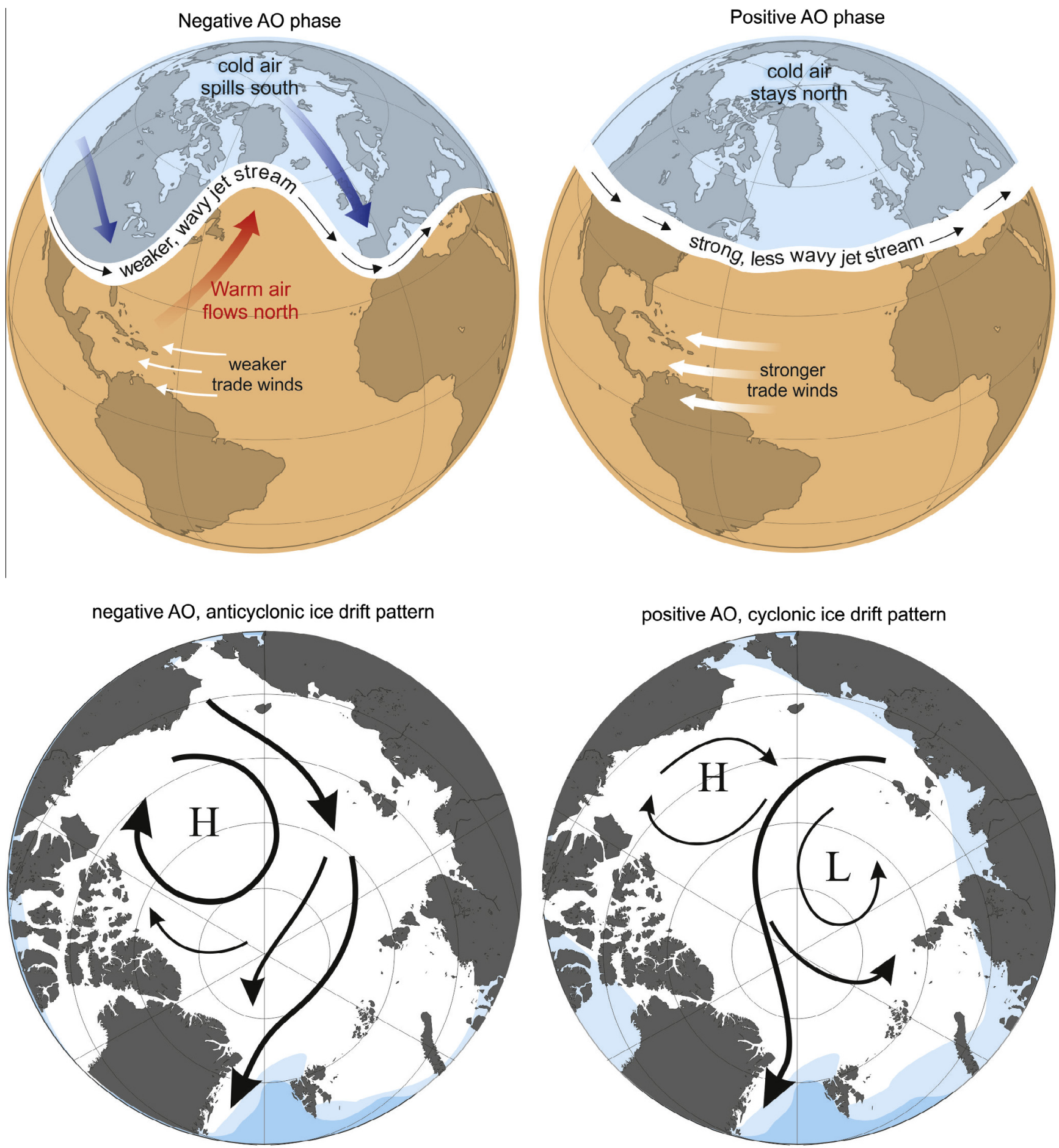

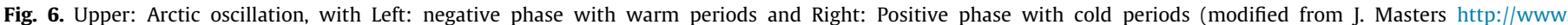

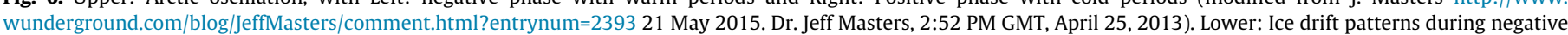
and positive phases of the Arctic oscillation (modified from Ugryumov and Korovin (2005)).

Pacific sector, with variability in the tropical region of the Pacific Ocean associated with the El-Nino Southern Oscillation being particularly important. The low-high latitude connections are related to the Pacific South American Mode, which is a series of quasistationary mean sea-level pressure anomalies that link the central tropical Pacific to the Amundsen and Bellingshausen seas (Turner, 2004). This teleconnection is strongest in austral winter and is not present in summer. The influences of El-Nino Southern Oscillation are episodic and non-linear, and there are complex interactions with other Southern Hemisphere climate modes (Turner and Marshall, 2011). The Pacific South American Mode teleconnection acts over rather short time-scales of days to weeks, but the signals can propagate eastwards to other sectors of the Southern Ocean over longer time-scales. However, separating these within the large intrinsic variability found at high southern latitudes presents a number of problems.

The Antarctic generally has zonally-symmetrical mean sea level pressure and winds (Fig. 5), which reflect the lack of major land 
masses immediately north of the Antarctic continent. The mean sea level pressure field is dominated by the belt of low mean sea level pressure between $60^{\circ}$ and $70^{\circ} \mathrm{S}$, known as the circumpolar trough, which is present because of the large number of storms that move south from mid-latitudes or develop in the strong thermal gradient just north of the Antarctic coast. These annular winds drive the major annular current of the Southern Ocean, the Antarctic Circumpolar Current, and its associated eddies (Langlais et al., 2015).

The pattern of atmospheric circulation around the Antarctic is dominated by an alternating system of low and high pressure systems (a wave number 3 pattern, Turner and Marshall, 2011), with low pressure centers around $20^{\circ} \mathrm{E}, 110^{\circ} \mathrm{E}$ and $130^{\circ} \mathrm{W}$. Interannual variability in this pattern changes the geopotential height field resulting in fluctuations between zonal (or meridional) patterns of circulation (Raphael, 2007; Turner and Marshall, 2011). The clockwise wind flow around the Amundsen Sea Low is responsible for the relatively warm, northerly winds on the West Antarctic Peninsula and the cold, southerly winds that flow over the Ross Sea. North of the circumpolar trough there is the belt of strong westerly winds over the Southern Ocean, while to the south of the trough there are coastal easterlies.

The low pressure center in the Ross Sea - Amundsen Sea region is known as the Amundsen Sea Low and is the most variable region of the Antarctic atmosphere (Kreutz et al., 2000; Turner and Marshall, 2011; Turner et al., 2015). This is the high-latitude end of the Pacific South America Mode and hence is the main region where El-Nino Southern Oscillation variability impacts the Southern Ocean. Increased intensity of the Amundsen Sea Low over recent decades has been associated with Antarctic-wide atmospheric changes that relate to the formation of the ozone hole (Turner et al., 2009; Fogt and Zbacnik, 2014), and has dominated changes in wind stress across the region. Lower ozone concentrations over recent decades have been linked to summer strengthening (of $\sim 15-20 \%$ ) of the large-scale clockwise winds, which have acted to further isolate Antarctica atmospherically (Turner et al., 2005a, 2005b). This strengthening of the westerlies (Marshall et al., 2006) is demonstrated by changes in the Southern Annular Mode index, which is a measure of the principal mode of variability in the atmospheric circulation of the Southern Hemisphere (Fig.7). Over the same period, interannual variability associated with the intensity of the Amundsen Sea Low has dominated the fluctuations in ocean temperatures and sea ice in the Southeast Pacific and West Atlantic sectors of the Southern Ocean.

The Southern Annular Mode index generally increased from 1970 to about 2000, and positive values have been related to an increase of greenhouse gas concentrations and depletion of stratospheric ozone (Thompson et al., 2011) There have been associated decreases in sea-ice extent and duration in the Bellingshausen Sea and Antarctic Peninsula regions of the Southern Ocean (Lefebvre et al., 2004; Stammerjohn et al., 2008a, 2008b), and increases in sea-ice cover in the Ross Sea (Lefebvre et al., 2004; Stammerjohn

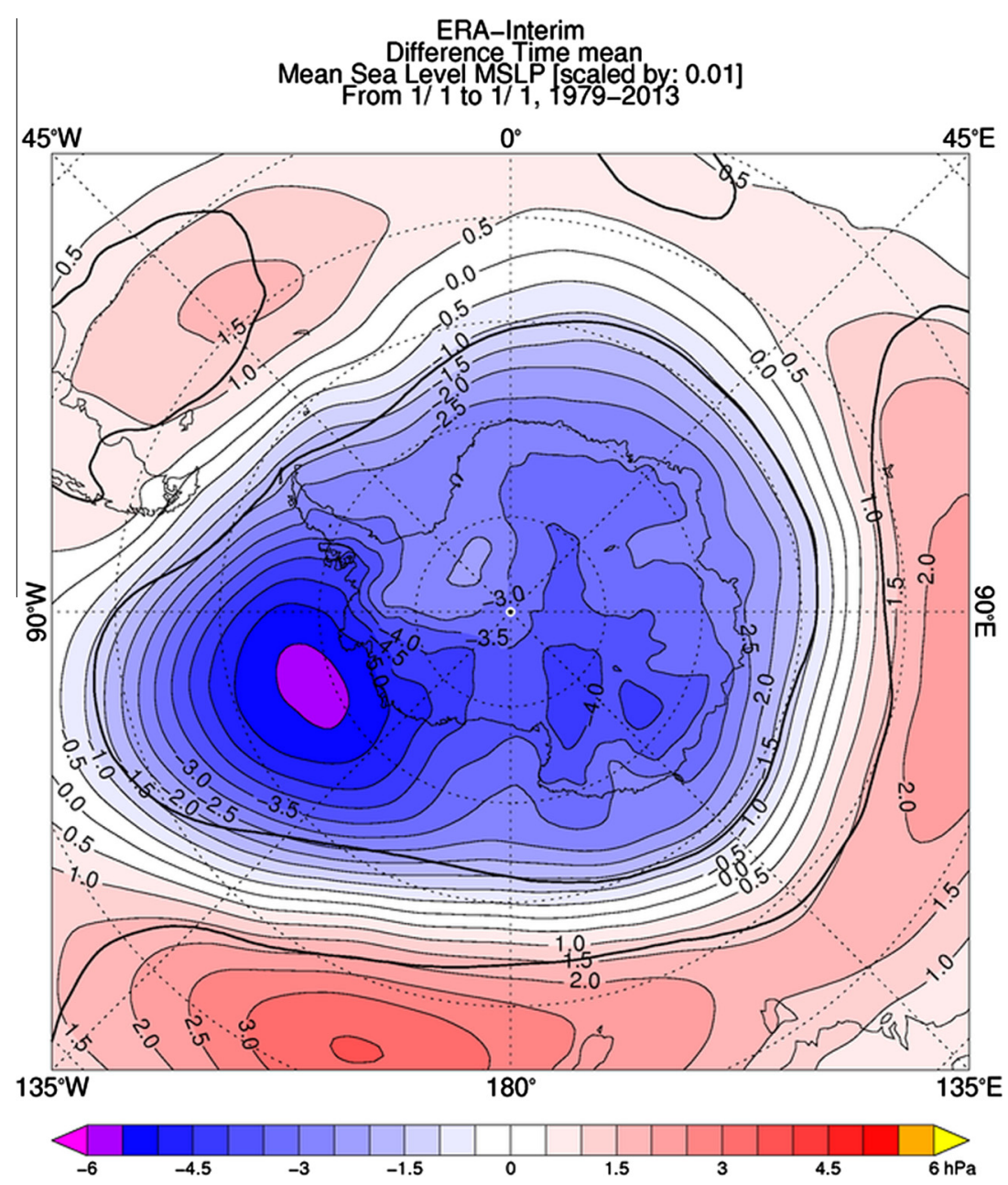

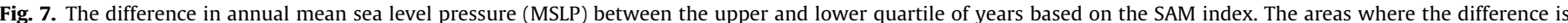

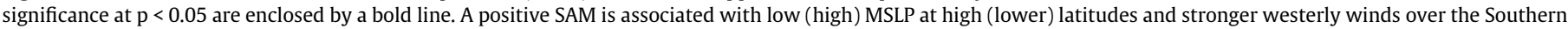
Ocean and a deeper Amundsen Sea Low. 
et al., 2008b). This strengthening of the westerlies has contributed to cooling air temperatures over eastern Antarctica and the Antarctic plateau, but warming over the Antarctic Peninsula (Thompson and Solomon, 2002; Turner et al., 2005a, 2005b; Stammerjohn et al., 2008b). Regional warming in western Antarctica has also been linked to increased sea surface temperatures in the tropical Pacific that generate long, quasi-stationary atmospheric waves (Rossby waves), leading to southward advection of warm air associated with the Pacific South America Mode towards the west coast of Antarctica (Stammerjohn et al., 2008a; Ding et al., 2011). However, the large annual variability and limited number of land-based stations acquiring data have resulted in the conclusion of no significant trend in mean air temperature for the Antarctic as a whole (IPCC, 2013).

\section{Physical oceanography}

\subsection{Physical conditions and circulation in the Arctic}

The Arctic Ocean consists of four deep basins (Canada, Makarov, Nansen, and Amundsen) (maximum depth $\sim 3000-4000 \mathrm{~m}$ ) separated by seafloor ridges (Lomonosov, Gakkel, Alpha, and Mendeleev) that are surrounded by broad, shallow (typically $<150 \mathrm{~m}$ ) continental shelves (Chukchi, Beaufort, Barents, Kara, Laptev and East Siberian seas; Fig. 1). Flow from the Pacific through the shallow (50 m) and narrow (85 km) Bering Strait (Fig. 2) from 1990 to 2004 resulted in an annual mean northward transport of $\sim 0.8 \pm 0.3 \mathrm{~Sv}$ (Roach et al., 1995; Woodgate et al., 2005b). Between 2002 and 2013 (with the exceptions of 2005 and 2012), the flow exceeded this climatological mean transport with a maximum flow of $1.1 \mathrm{~Sv}$ in 2011 (Woodgate et al., 2012, 2015). These mean flows are primarily driven by a Pacific-Arctic pressure head (difference in sea level height between the North Pacific and the Arctic Ocean) (Stigebrandt, 1984; Aagaard et al., 2006). Earlier estimates indicated the pressure head was $\sim 0.7 \mathrm{~m}$, but from 2001 to 2011, it increased by approximately 30\% (Woodgate et al., 2012). The Pacific inflow is a source of heat, freshwater, and nutrients to the Arctic Ocean (Walsh et al., 1989; Woodgate et al., 2005a).

The greatest water mass and volume exchange between the Arctic and the Atlantic is through Fram Strait, the deep channel between Greenland and Spitsbergen, with a maximum depth of $\sim 2600 \mathrm{~m}$ (Fig. 3). The residual transport through the Strait $(\sim 2 \mathrm{~Sv}$ ) consists of $12 \mathrm{~Sv}$ into the Arctic on the eastern side and $14 \mathrm{~Sv}$ flowing out on the western side, but with high variability (Rudels et al., 2008; Schauer et al., 2008). Other exchanges with the Atlantic (Fig. 3) include a net inflow into the Barents Sea of $\sim 2$ Sv (Skagseth et al., 2008; Smedsrud et al., 2010). These waters flow through the Barents Sea, losing heat during transit, and eventually enter the Arctic Basin via the St. Anna Trough (Smedsrud et al., 2010) (Fig. 3). An additional net outflow from the Arctic of approximately $1.8 \mathrm{~Sv}$ runs through the Canadian Archipelago (Melling et al., 2008).

Despite numerous efforts to measure accurately the mean volume fluxes through the various gateways to and from the Arctic Ocean, they only balance to within the uncertainties of the estimates (Beszczynska-Möller et al., 2011). These uncertainties are relatively large due to several factors, including large variability on time scales of days to decades, relatively short-term data sets, and incomplete observational coverage across the exchange regions. Also, non-overlapping time periods of the measurements may contribute to the failure to balance the mean volume flows into and out of the Arctic. The difficulties in balancing the volume flows result in an inability to balance other fluxes such as heat and nutrients.

The dominant Arctic surface circulation features include the Transpolar Drift that flows from the Pacific Sector of the Arctic towards Fram Strait, the clockwise Beaufort Gyre located over the Canada Basin, and low-salinity boundary currents within the riverine coastal domain (Carmack et al., 2015) that flow around the continental shelves in a counter-clockwise direction (Fig. 1). Pacific Water, which enters through Bering Strait, tends to remain in the upper layers $(<200 \mathrm{~m})$ of the Arctic owing to its density being less than that of the Atlantic Water of the Canada Basin. Pacific Water eventually flows south out through Fram Strait into the Greenland Sea (Falck et al., 2005) or through the Canadian Arctic Archipelago and into the Labrador Sea (Jones et al., 2003), in both cases influencing sub-Arctic regions (Fig. 1). Dense Atlantic Water enters Fram Strait to form the intermediate and deep layers of the Arctic Ocean (Rudels et al., 1994).

The residence time of the upper layers of the Arctic Ocean is estimated to be 5-10 years (Ekwurzel et al., 2001; Macdonald et al., 2003), owing to the relatively rapid circulation in the boundary currents around the basin. Mean currents in the central basin tend to be relatively weak; however, eddies may accelerate the transit times. In the sub-halocline waters, the estimated residence times are much longer, on the order of several hundred years (Schlosser et al., 1994; Macdonald et al., 2003).

Approximately $2400 \mathrm{~km}^{2}$ of freshwater is seasonally added through river runoff directly into the Arctic each year; this freshwater is augmented by nearly equal amounts of freshwater arriving through Bering Strait and from precipitation (Aagaard and Carmack, 1989; Serreze et al., 2006; Carmack et al., 2015). The freshwater helps to maintain low salinities and strong vertical stratification in the upper Arctic Ocean and isolates the warmer, saltier and denser Atlantic Water in the subsurface layers (Aagaard et al., 1981). In recent years, coastal runoff into the Arctic has increased (McClelland et al., 2006). Most of this freshwater eventually enters the sub-Arctic seas, although recently there has been an increase in the storage of freshwater within the Canada Basin (Karcher et al., 2005; Proshutinsky et al., 2009; Giles et al., 2012). Freshwater outflow from the Arctic occurs through Fram Strait and the Canadian Archipelago, and can alter overturning circulation locations and rates in the Greenland and Labrador seas. At times, the freshwater influence of Arctic outflows can be traced as salinity anomalies within the northern North Atlantic (Sundby and Drinkwater, 2007); they may reach as far south as the Gulf of Maine (Greene and Pershing, 2007).

High variability on interannual and decadal time scales occurs in Arctic circulation patterns. In the central Arctic during the 1970s through to the mid-1990s, surface winds typically produced anticlockwise motion, strong Transpolar Drift, and a large Beaufort Gyre (Morison et al., 2012). In the late 1990s and into the 2000s, higher clockwise winds caused by a stronger Beaufort High resulted in a shift of the Transpolar Drift closer to North America and a smaller Beaufort Gyre (Morison et al., 2012). These changes, along with the increased storage of freshwater in the Beaufort Gyre, are linked to an increase in the Arctic Oscillation index (Fig. 6). Many Arctic regions cooled by $0.5^{\circ} \mathrm{C}$ per decade over 1930-1965 during a mostly negative phase of the Arctic Oscillation, while warming occurred over 1965-1995 when the Arctic Oscillation was mostly in a high phase (Steele et al., 2007).

\subsection{Physical conditions and circulation in the Antarctic}

No land masses extend north-south across the Southern Ocean, which allows a circumpolar flow around Antarctica driven by the strong westerly winds (Langlais et al., 2015). This ocean current, the Antarctic Circumpolar Current (Fig. 4) connects the world's ocean basins. The major water mass of the Antarctic Circumpolar Current is Circumpolar Deep Water, which is derived from deepwater flows and formation across the North Atlantic. Circumpolar Deep Water upwells as it moves south across the Antarctic Circum- 
polar Current and reaches the surface in areas near the continent. In the northern regions of the Antarctic Circumpolar Current, surface water masses sink as they flow northwards into the surrounding ocean basins. In areas close to the continent, where sea ice is formed and interactions with ice shelves occur, very dense water is generated that sinks and forms Antarctic Bottom Water. This water mass spreads out across the deep ocean and is a key element in driving global thermohaline circulation.

The surface Southern Ocean is a relatively isolated regime (Longhurst, 1998), having been nominally separated from the other ocean basin water masses for about 25-30 million years by the series of deep eastward flowing jets that comprise the Antarctic Circumpolar Current system (Rintoul et al., 2001; Lawver and Gahagan, 2003) (Fig. 4). Much of the transport in the Antarctic Circumpolar Current (previously referred to as the West Wind Drift) is contained in zonal jets associated with circumpolar fronts. However, within the Antarctic Circumpolar Current there also exist numerous eddies, meanders, and other mesoscale features (Langlais et al., 2015). Mean wind stresses drive surface flow equatorward through Ekman transport, which is nearly balanced by poleward eddy fluxes (Karsten and Marshall, 2002).

The Antarctic Circumpolar Current frontal zones are functionally water mass boundaries, but their locations are highly variable (Orsi et al., 1995; Sokolov and Rintoul, 2009a, 2009b). From north to south they are: the sub-Antarctic Front, the Antarctic Polar Front, the Southern Antarctic Circumpolar Current Front, and the Southern Boundary of the Antarctic Circumpolar Current (Orsi et al., 1995). The first denotes the northern boundary of the Antarctic Circumpolar Current and the southern boundary of the subAntarctic waters. Farther south is the Antarctic Polar Front, also referred to as the Antarctic Convergence. There, the northward flowing cold Antarctic waters submerge below the warmer more northerly Antarctic Intermediate waters. The strong horizontal temperature gradients between these two are an effective physiological barrier to the exchange of organisms between sub-Antarctic and Antarctic ecosystems (Patarnello et al., 1996). The Southern Boundary of the Antarctic Circumpolar Current roughly separates the Upper Circumpolar Deep Water to the north from the Lower Circumpolar Deep Water to the south.

Closer to the continent, the Antarctic Coastal Current (previously known as the East Wind Drift) follows the Antarctic coastline and is a discontinuous current that flows counter to the Antarctic Circumpolar Current (Tchernia and Jeannin, 1980; Moffat et al., 2008; Núñez-Riboni and Fahrbach, 2009) (Fig. 4). It is driven by the polar easterlies caused by airflow off the Antarctic land mass. An associated shelf-break front is known as a transport avenue for icebergs and an area of high biological activity (Ainley and Jacobs, 1981; Jacobs, 1991; Ainley et al., 1998; Williams et al., 2010). The Southern Boundary of the Antarctic Circumpolar Current roughly separates the Antarctic Coastal Current from the Antarctic Circumpolar Current. In numerous locations, the Antarctic Circumpolar Current (and other coastal currents, e.g., ShelfSlope Current) impinges on the slope causing intrusions of Circumpolar Deep Water onto the shelf and providing a source of heat and nutrients to the shelf (Jacobs, 1991; Meijers et al., 2010; Williams et al., 2010; Dinniman et al., 2011; Assmann et al., 2013). For example, at the West Antarctic Peninsula, upwelling of warm, high-nutrient Circumpolar Deep Water influences ocean and ice physics and ecosystem processes.

The Antarctic Circumpolar Current is the dominant flow, with an estimated volume transport of up to $174 \pm 22 \mathrm{~Sv}$ (Damerell et al., 2013); it extends to a depth of $2000-4000 \mathrm{~m}$, and is up to $2000 \mathrm{~km}$ wide. Since the 1950s, strengthening of the westerly winds may have shifted the Antarctic Circumpolar Current southward and resulted in slight changes in frontal positions (Sokolov and Rintoul, 2009a, 2009b; Downes et al., 2011). The effect of the increased wind strength is, however, the subject of some debate as it appears to have led to an intensification of the eddy activity rather than an increase in Antarctic Circumpolar Current speed (Fyfe and Saenko, 2005; Meredith and Hogg, 2006; Böning et al., 2008; Hogg et al., 2008, 2015; Downes et al., 2011; Downes and Hogg, 2013).

Southern Ocean water temperatures have, in some sections, been increasing in recent years (Gille, 2002, 2008; Whitehouse et al., 2008), probably associated with the southward movement of the Antarctic Circumpolar Current caused by the current's increasing intensity (Böning et al., 2008). At the same time and in some areas, the strengthened winds have led to an increased flux of relatively warm, nutrient-rich Circumpolar Deep Water onto the continental shelves through Ekman-induced upwelling (Dinniman et al., 2011). The relatively rapid flow of the Antarctic Circumpolar Current and the opposing Antarctic Coastal Current flows can connect water in the near surface layers from opposite sides of the Southern Ocean in less than 3 years (Thorpe et al., 2007).

The Antarctic Circumpolar Current generally provides zonal connectivity between different areas. However, there are some large latitudinal shifts within the Antarctic Circumpolar Current associated with strong steering by bathymetry (Orsi et al., 1995; Sokolov and Rintoul, 2009a; De Broyer and Koubbi, 2014). This is particularly marked in the Scotia Sea, which lies to the East of Drake Passage. West of the Antarctic Peninsula, the Southern Antarctic Circumpolar Current Front occurs close to the Southern Boundary of the Antarctic Circumpolar Current at $\sim 65^{\circ} \mathrm{S}$, while to the east in the northern Scotia Sea it occurs north of $55^{\circ} \mathrm{S}$, reflecting a strong northward component of the Antarctic Circumpolar Current flow east of Drake Passage (Fig. 4). The Antarctic Peninsula and the mountainous Scotia Arc that connect the Antarctic Peninsula with South America cause deflection of the current to the northeast, with the deeper waters flowing through a number of restricted passages that cut across the Scotia Arc. This also results in upwelling of deeper waters that has important influences on epipelagic ecological processes by disrupting the zonal pattern of the Southern Ocean (Murphy et al., 2007a; Atkinson et al., 2008). Large changes in the latitude of the flow of the Antarctic Circumpolar Current are also apparent in other regions, such as the Pacific Antarctic Ridge and the Kerguelen Plateau (Williams et al., 2010; De Broyer and Koubbi, 2014).

The Ross and Weddell Gyres (Fig. 4) are large-scale clockwise circulation features that are formed by the interaction between the Antarctic Circumpolar Current and the Antarctic Continental Shelf. As the Coriolis force acts to the left in the Southern Hemisphere, the resulting Ekman transport is directed outward from the gyres' centers; thus these regions are the sites of upwelling of relatively warm, nutrient-rich water. In the Weddell Sea, the gyre is dominated by a strong seasonally-varying boundary current around the basin that is several hundred kilometers wide and carries approximately $90 \%$ of the $30 \mathrm{~Sv}$ transport of the gyre (Fahrbach et al., 1994). Flows in the interior of the gyre tend to be weak, transporting less than $4 \mathrm{~Sv}$ and are dominated by shorter-term variability. Warm Circumpolar Deep Water is advected onto the continental shelves through wind forcing in limited locations associated with specific bathymetric features (Dinniman et al., 2003). Between the 1950s and 2000, increased precipitation, melting of the West Antarctic Ice Sheet, and reduced sea-ice production caused by warmer ocean temperatures have resulted in freshening of the waters of the Ross Sea continental shelf (Jacobs et al., 2002). This freshening is expected to have significant future impacts on the Ross Sea's contribution of deep water and the oceanic thermohaline circulation (Smith et al., 2014a). Elsewhere around the continent south of the Southern Boundary of the Antarctic Circumpolar Current, the oceanographic flows are complex and influenced by local and regional topographic conditions, resulting 
in a series of meso-scale gyres during summer (Nicol et al., 2000; Nicol, 2006; Williams et al., 2010).

Regional Southern Ocean temperatures and sea ice vary with changes in the atmospheric and oceanic circulation. Changing influences of warm and cold air flows and oceanic temperature anomalies advected by ocean currents result in fluctuations in winter sea-ice extent (Murphy et al., 1995; Nicol et al., 2000, 2008a, 2008b; Kwok and Comiso, 2002a, 2002b; Comiso et al., 2011; Turner and Marshall, 2011). These latter variations are most marked in the Amundsen Sea and Bellingshausen seas and South Atlantic regions, and are linked to changes in atmospheric circulation in the area of the Amundsen Sea Low (Yuan and Martinson, 2001; Turner and Marshall, 2011). Decadal variations in these processes involve complex interactions in Southern Hemisphere atmosphere and ocean processes with the Southern Annular Mode, El Niño-Southern Oscillation, and other climate modes (Murphy et al., 1995, 2014; Kwok and Comiso, 2002a, 2002b; Stammerjohn et al., 2008b; Comiso et al., 2011; Turner and Marshall, 2011; Clem and Fogt, 2013; Yu et al., 2015).

\section{Sea ice and its biota}

In both Polar Regions, sea ice is impacted by heat advected in the atmosphere and the ocean, and is itself advected by currents and wind. Because sea-ice movement is a function of wind on short time-scales, as well as ocean currents and internal stress, sea ice moves in a different manner than the underlying ocean. On shallow shelves, immobile land-fast ice that is anchored to the seafloor can isolate the underlying ocean waters from wind forcing. Drifting ice is classified as first-year ice (generally $<2 \mathrm{~m}$ thick), and multiyear ice (usually $>2 \mathrm{~m}$ thick). First-year ice forms over shelf and basin regions that have been ice-free during the previous summer (e.g., Carmack et al., 2006). Multi-year ice is relatively scarce in the Antarctic, and most common in the central Arctic (Fig. 8). First-year ice is more responsive to wind forcing and may be more susceptible to deformation. The recent replacement of multi-year ice with first-year ice in the Arctic (Rothrock et al., 2008) is associated with a higher mobility of sea ice there (Babb et al., 2013).

Sea-ice biota includes organisms that live in and/or on sea ice, or are associated with it (Horner et al., 1992; Ackley and Sullivan, 1994; Arndt and Swadling, 2006). First-year ice represents a simpler habitat than multi-year ice since the former generally consists of a relatively flat under-surface interrupted by pressure ridges (Fig. 9). In contrast, multi-year ice provides a more stable and complex environment with large ridges and tunnels formed by rafted and refrozen ice. Thus, multi-year ice often harbors a more diverse biota with higher abundance and biomass of sympagic fauna than first-year ice (Hop et al., 2000; Arndt and Lønne, 2002) (Fig. 9). Sea-ice organisms are transported with the ice as it moves. Upon melting, these organisms either join the pelagic community or sink to the bottom where they fuel the benthos (Poltermann, 1998; Werner et al., 1999; Berge et al., 2012). Sea ice also transports sediments and wind-deposited dust and its associated trace elements (Nürnberg et al., 1994). This transport can be important for plankton blooms and carbon export in regions that are replete with macro-nutrients, but depleted of micro-nutrients such as iron (Aguilar-Islas et al., 2008).

\subsection{Transport of sea ice in the Arctic and Antarctic}

The Transpolar Drift is the main export route for sea ice exiting the central Arctic basin (Vinje, 2001; Pavlov et al., 2004). It transports both multi-year ice and first-year ice south through Fram Strait into the Greenland and Iceland seas (Fig. 3), where the majority of the ice eventually melts (Vinje, 2001; Rigor et al.,
2002). Ice formed along the Siberian Coast is transported within 3-5 years towards the Greenland Sea, whereas ice originating from the central and western Arctic Ocean needs at least 5 years to reach Fram Strait (Rigor et al., 2002). Variability in the origin of the ice that is transported out of the Arctic is affected by atmospheric pressure anomalies and associated wind stresses (Rigor et al., 2002; Ogi and Rigor, 2013).

Around $15 \%$ of the ice volume in the Arctic Ocean is transported annually out through Fram Strait (Kwok, 2009) (Fig. 3), with the largest seasonal transport during the winter (Hop and Pavlova, 2008). The annual ice transport south through Fram Strait (areal transport $706 \mathrm{~km}^{2} \mathrm{y}^{-1}$, volume transport $2200 \mathrm{~km}^{3} \mathrm{y}^{-1}$; Kwok, 2009) is approximately three times the areal transport into the Barents Sea from the Arctic (Hop and Pavlova, 2008). Comparatively little ice $\left(100-140 \mathrm{~km}^{3} \mathrm{y}^{-1}\right)$ is transported through Bering Strait on an annual basis; it largely forms in the Bering Sea and is advected into the Arctic (Woodgate and Aagaard, 2005; Babb et al., 2013). The southern limit of the sea ice in the Bering Sea occurs where the rate of southward advection is equal to the rate of melting from contact with warmer waters and varies greatly within and between years (Pease, 1980; Niebauer et al., 1999; Stabeno et al., 2001).

In the Southern Ocean, the Southern Boundary of the Antarctic Circumpolar Current tends to be the northern limit of winter seaice extent. Ice drift in the Southern Ocean is greatly affected by the eastward flow within the Antarctic Circumpolar Current and a northward dispersal via Ekman transport. Sea ice is also advected by the Ross and Weddell Gyres (Schwegmann et al., 2011), as well as in smaller mesoscale gyres (Nicol et al., 2000; Nicol, 2006). Near the coast, the Antarctic Coastal Current leads to a westward ice drift (Emery et al., 1997). Sea ice does occasionally drift across the Southern Boundary of the Antarctic Circumpolar Current, especially in the Weddell/Scotia Sea and Ross Sea regions. Between the Antarctic Circumpolar Current and the Antarctic Coastal Current, the Southern Ocean is largely a divergent region for sea-ice cover.

Icebergs are frequently released from the glaciers and ice shelves of Greenland and Antarctica and can have a substantial impact on both freshwater transport and the surrounding biotic community. Icebergs tend to be formed in large numbers at a limited number of locations and are advected by the prevailing currents in those regions (e.g., Gladstone et al., 2001). Icebergs melt during their movements, imparting fresh waters locally (e.g., K.L. Smith et al., 2007; W.O. Smith et al., 2007; Schwarz and Schodlok, 2008; Biddle et al., 2015) and provide a source of micro-nutrients (Raiswell et al., 2008). Upwelling in the immediate vicinity of icebergs, through vertical motion generated by subsurface ice melting, has been observed in fjords (Horne, 1985), as has wind-induced upwelling near grounded (Stern et al., 2015) and drifting icebergs (Duprat et al., 2016). This upwelling in turn can enhance primary production (Horne, 1985). These smallscale systems can have a significant impact because of their relatively slow movement and large numbers. It has been suggested that the iceberg effect is a significant component of the ecology of open waters in the Antarctic (Arrigo et al., 2002), but a panAntarctic quantitative assessment is lacking.

In both Polar Regions, icebergs have a strong impact on the benthos through deposition of ice-rafted material over large regions of the ocean through iceberg drift (Thomas et al., 1995) and disturbances of shallow shelf benthic communities through iceberg groundings (Gutt et al., 1996; Jones et al., 2007). Iceberg scouring of the benthos occurs more frequently in the Arctic than the Antarctic owing to the shallower shelves in the former (Clarke, 1996).

\subsection{Advection of sea-ice biota in the Arctic and its fate}

Advection of sea-ice fauna in the Arctic may be considered in two ways: advection through ice drift while associated with the 


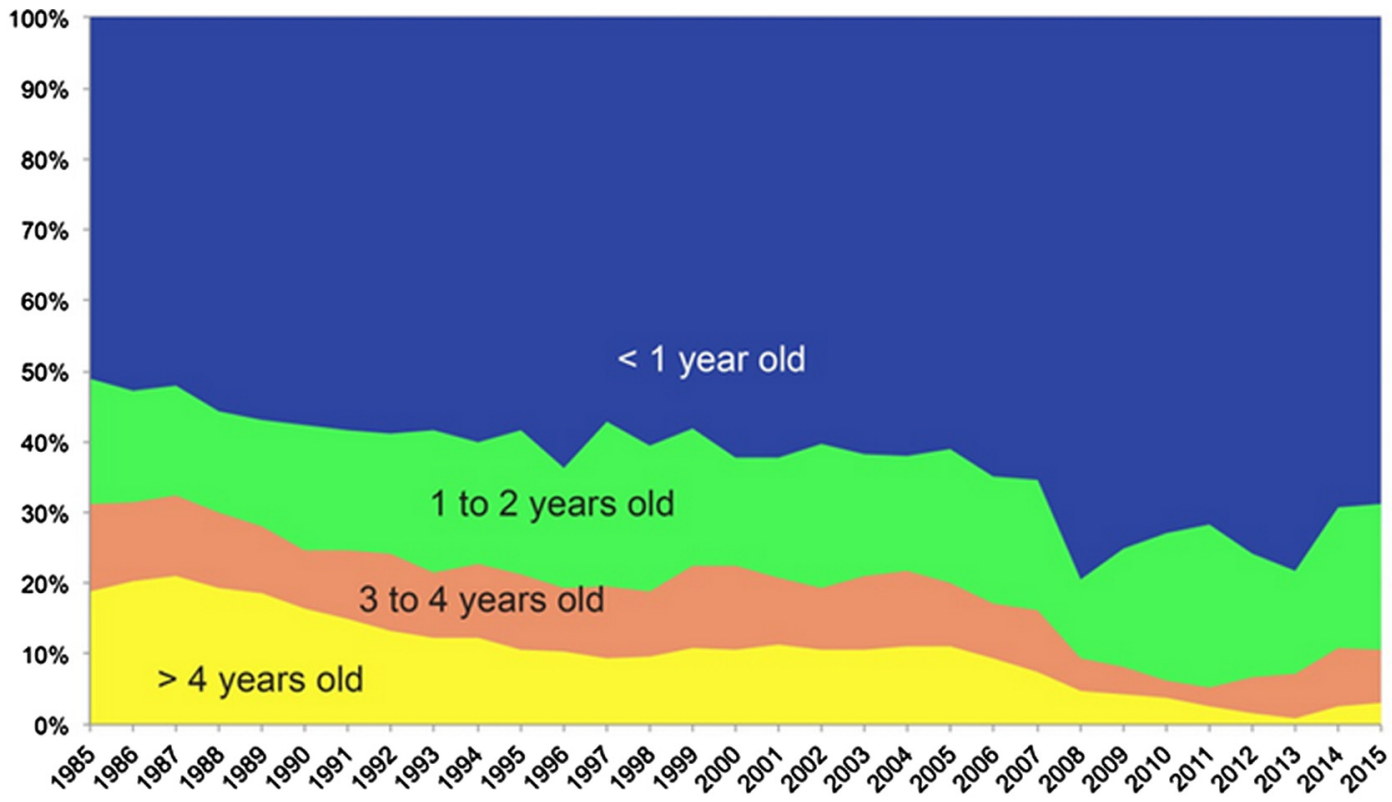

\section{March 1985}

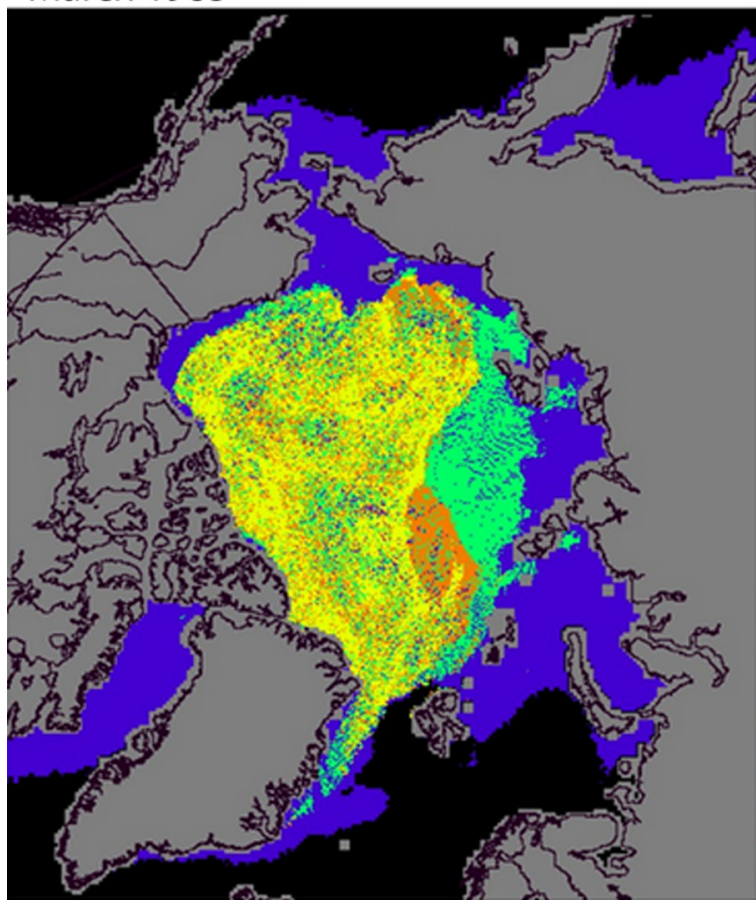

March 2015

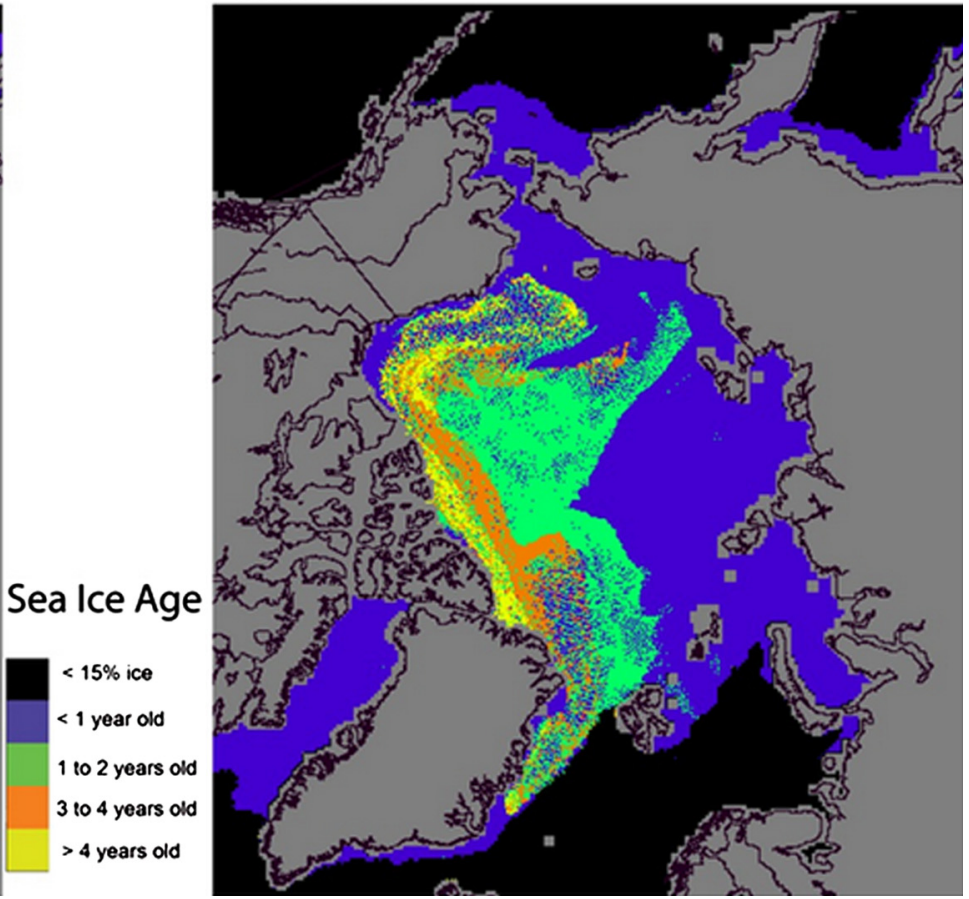

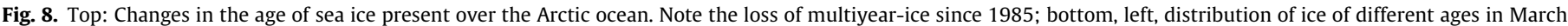

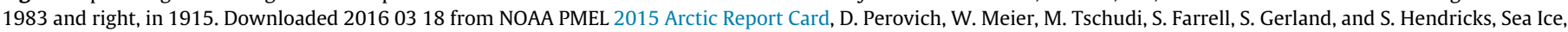
http://www.arctic.noaa.gov/reportcard/sea_ice.html.

sea ice, or through ocean currents once released (passively or active migration) into the underlying water masses. The distribution of sea-ice biota within the Arctic is determined by the characteristics of the sea ice itself: structure, thickness and age, as well as by seasonal cycles of melting and accretion at the underside of ice floes. Wind and surface currents transport sea ice and associated biota around, and eventually out of, the Arctic (Hop and Pavlova, 2008). The main regional differences in the species composition of the sea-ice fauna are found in fast ice, which also tends to contain more species with partly benthic life cycles (e.g., Pike and Welch, 1990; Melnikov, 1997; Weslawski and Legezynska, 2002).
Estimates of the biomass (wet weight) of sympagic amphipods transported out of the Arctic range between 478 and $3800 \times 10^{3}$ tons $\mathrm{y}^{-1}$ for export to the Greenland Sea and between 150 and $194 \times 10^{3}$ tons $\mathrm{y}^{-1}$ to the Barents Sea (Arndt and Lønne, 2002; Hop et al., 2006; Wassmann et al., 2006; Hop and Pavlova, 2008). The biomass transported depends not only on the ice flux, but also on the type and origin of the ice. Recent losses of multi-year ice are expected to decrease the southward transport of ice fauna and flora, thereby reducing the carbon contribution to sub-Arctic seas. High biomass export was observed in the 1980s in Fram Strait and north of Svalbard (Lønne and Gulliksen, 1991; Arndt and Lønne, 
First year ice
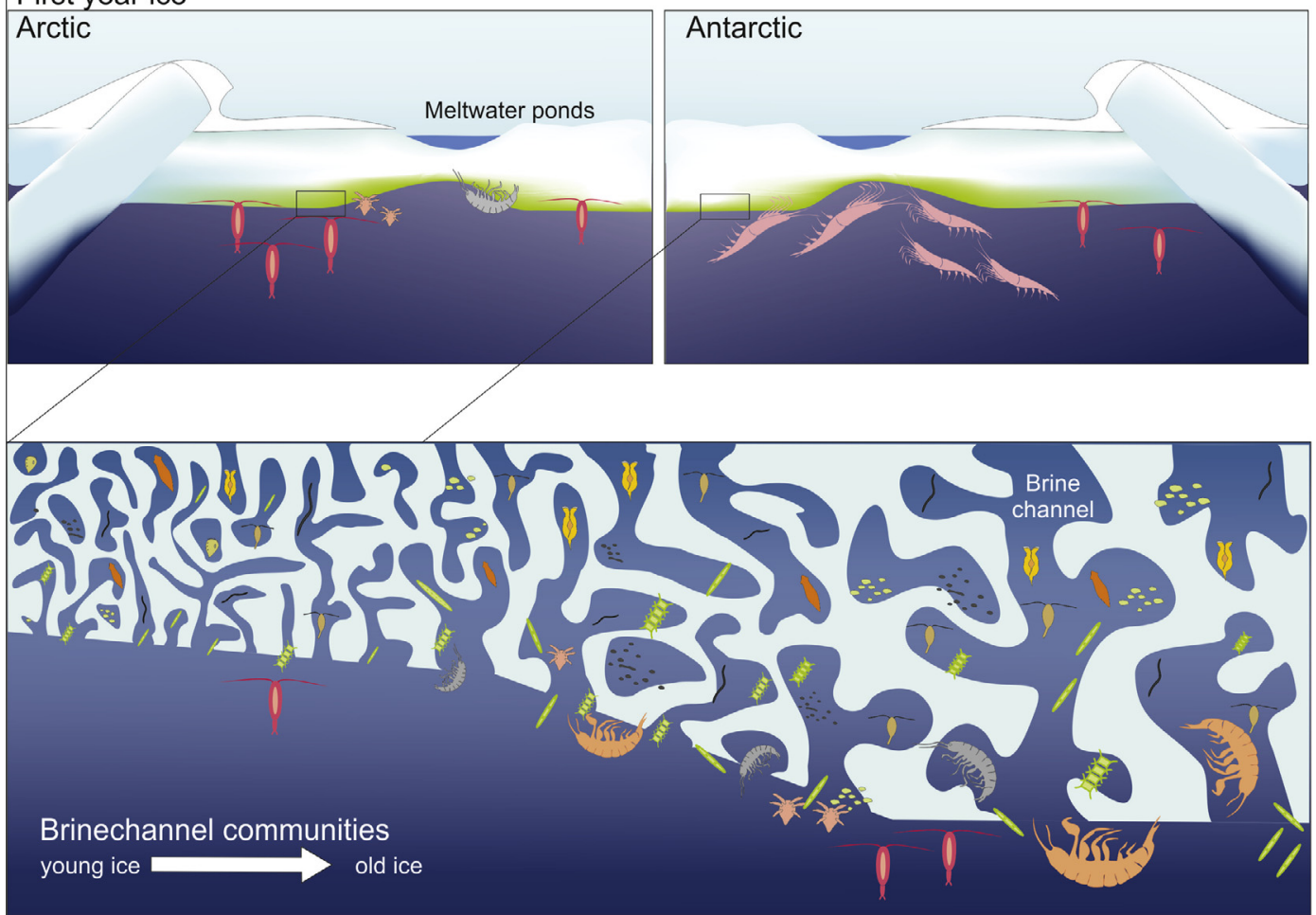

Brinechannel communities
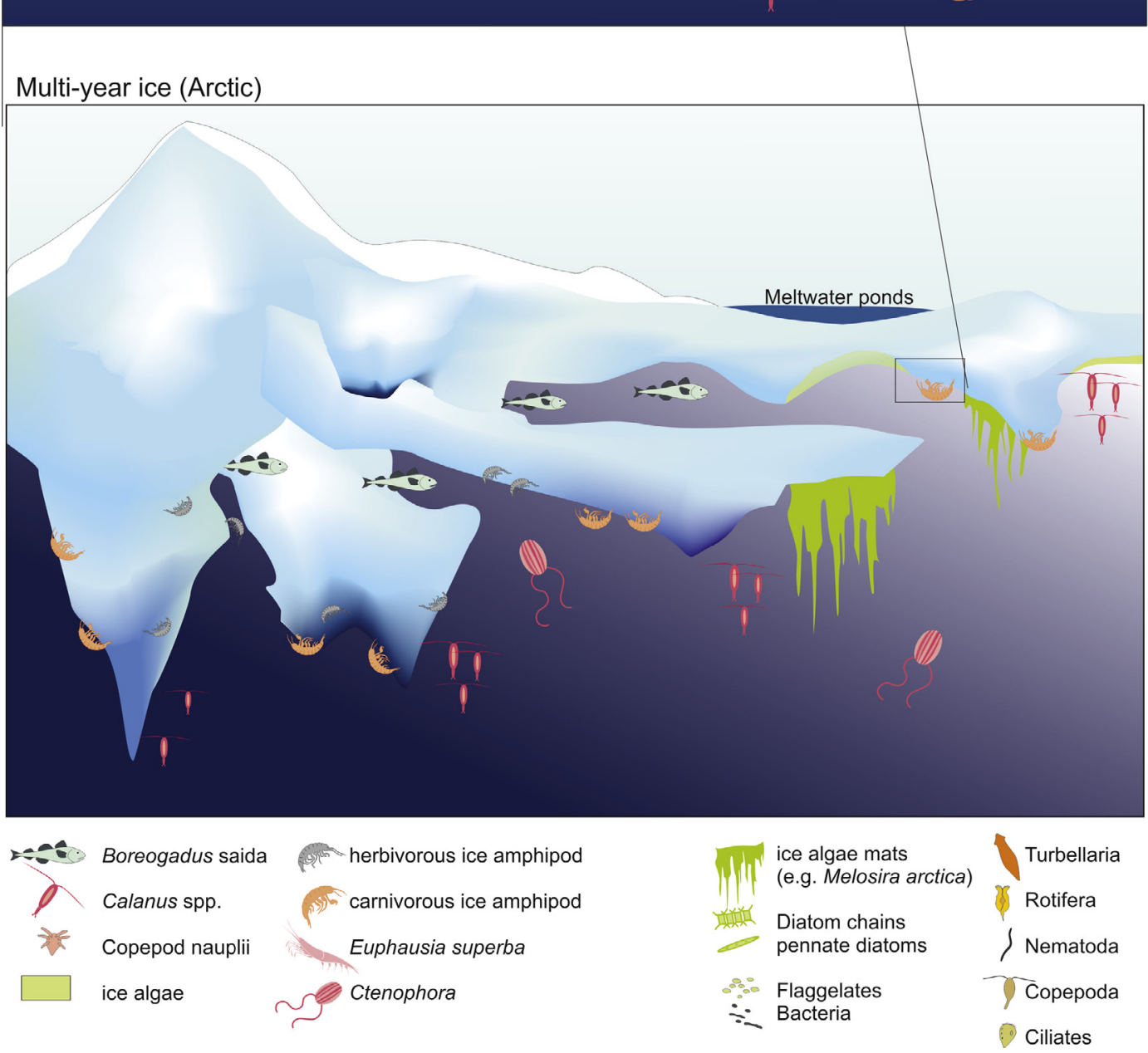

Fig. 9. Cartoon of sympagic fauna associated with first year ice and multi-year ice. 
2002) as a consequence of a large export of thick multi-year ice from the central Arctic (Rigor et al., 2002). In the 1990s, winds associated with a prevailing positive Arctic Oscillation drove a high proportion of young, thin ice from the eastern Arctic towards Fram Strait (Rigor et al., 2002), which resulted in a relatively low export of amphipod biomass between 1998 and 2002 (Arndt and Pavlova, 2005). During the past decade, the abundance and biomass of iceassociated amphipods, particularly Gammarus wilkitzkii, have declined (Hop and Pavlova, 2008; Barber et al., 2015).

Biota associated with sea ice that exits the Arctic is likely "lost" from the system, as the ice will eventually melt and release the sympagic community into the water column in the sub-Arctic (Werner et al., 1999). Ice fauna released over deep water will be dispersed over vast areas as they sink towards the seafloor (Arndt and Pavlova, 2005; Hop and Pavlova, 2008), thereby contributing to both pelagic and benthic food webs (Werner et al., 1999). Sympagic fauna released from sea ice over the Arctic shelves and in sheltered areas may be retained during the ice-free period in the water column or in the benthos, from which they can subsequently recolonize a new ice substrate when ice reforms (Poltermann, 1998; Arndt et al., 2005). Berge et al. (2012) suggested that the ice amphipod Apherusa glacialis is adapted to seasonal habitats by migrating to deeper waters where counter currents transport them northward, thus retaining populations within the sea-ice zone.

\subsection{Advection of sea-ice biota in the Antarctic and its fate}

The circumpolar patterns of seasonal sea-ice drift in the Antarctic strongly affect the distribution of planktonic organisms associated with Antarctic sea ice, which typically lead to species having circumpolar distributions (Dahms et al., 1990; Kirkwood, 1993; Metz, 1995; Costanzo et al., 2002). Larval and juvenile stages of Antarctic krill (Euphausia superba) use the undersurface of the ice as a refuge from predation and as a source of food (Daly, 1990; Daly and Macaulay, 1991). By incorporating the effects of sea-ice advance/retreat and drift on transport pathways, Thorpe et al. (2007) demonstrated that krill interactions with sea ice were important in governing the variability of the circumpolar distribution of Antarctic krill (see also Nicol et al., 2000; Nicol, 2006).

Northward advection of sea ice in the Ross Sea along the Victoria Land Coast is driven by local winds and basin-scale ocean circulation (K.L. Smith et al., 2007). In spring, thin, young ice recently formed in the Ross Sea polynya can contain relatively high concentrations of ice algae (Arrigo et al., 2003). As the ice ages, it drifts northward and algal concentrations increase, reaching a peak at about $72^{\circ} \mathrm{S}$. At this stage, the algal community is dominated by diatoms (Arrigo et al., 2003). Over time, snow accumulates and reduces light transmission, and algal concentrations drop substantially. Thus, there is a net flux of sea-ice microalgae and their associated microbial community from the Ross Sea northward. A similar pattern might be expected for the Weddell Sea where the flow of ice is similar.

In the South Atlantic region of the Southern Ocean, the productivity of krill has been tied to the extent of seasonal sea-ice coverage (Siegel and Loeb, 1995; Quetin and Ross, 2003; Wiedenmann et al., 2009), which affects krill recruitment and larval survival (Kawaguchi and Satake, 1994; Siegel, 2000; Atkinson et al., 2004). Regional decreases in krill stocks since the 1970s are thought to be associated with the cumulative effects of sea-ice reduction in the Scotia Sea and west of the Antarctic Peninsula (Atkinson et al., 2004; Flores et al., 2012; Saba et al., 2014). In the East Antarctic, variation in the distribution of krill south of the Southern Boundary of the Antarctic Circumpolar Current has been linked to fluctuations in regional ocean circulation and seaice conditions (Nicol et al., 2000).

\section{Nutrients and primary production}

Primary production has been estimated in the Arctic $\left(>66^{\circ} \mathrm{N}\right.$, i.e., north of the Arctic Circle) at $\sim 1.5 \mathrm{Gt} \mathrm{C} \mathrm{yr}^{-1}$ (Arrigo and Van Dijken, 2011; Tremblay et al., 2015). Given that the area of the Arctic north of $66^{\circ} \mathrm{N}$ is $\sim 14 \times 10^{6} \mathrm{~km}^{2}$, production there, on average, is $\sim 107 \mathrm{~g} \mathrm{C} \mathrm{m}^{-2} \mathrm{yr}^{-1}$. Primary production in the Southern Ocean south of $50^{\circ} \mathrm{S}$ is between 2 and $4 \mathrm{GtC} \mathrm{yr}^{-1}$ (Moore and Abbott, 2000; Arrigo et al., 2008). The area of the Southern Ocean south of $50^{\circ} \mathrm{S}$ is $\sim 45 \times 10^{6} \mathrm{~km}^{2}$, and thus the average rate of primary production over the Southern Ocean is $\sim 44-89 \mathrm{~g} \mathrm{C} \mathrm{m}^{-2} \mathrm{yr}^{-1}$. In both polar regions, vertical and horizontal advection of nutrients, including micro-nutrients, to the euphotic zone play an important role in the local magnitude and spatial distribution of primary production. Part of the difference in primary production rates may be due to iron limitation over much of the Southern Ocean when compared to the Arctic.

\subsection{Impacts of advection on primary production in Arctic}

Waters entering the Arctic Ocean from the Pacific or the Atlantic can be delineated by their different nitrate:phosphate ratios, as well as their concentrations of dissolved silicate (Jones et al., 1998) (Fig. 10). These differences have been used to track Pacificderived Arctic waters into the Atlantic sub-Arctic (Jones et al., 1998; Falck et al., 2005). While the nutrient concentrations are higher in the Pacific, the higher volume transports from the Atlantic probably result in a higher nutrient flux into the Arctic from the latter. The input of nutrients to the Arctic Ocean basin by Arctic rivers is small (Le Fouest et al., 2013). Nutrient supply from the deep basins of the Arctic Ocean into the upper layers is restricted because of strong stratification (Aagaard et al., 1981), although in some shelf-slope areas, winter upwelling can fuel primary production (Falk-Petersen et al., 2015). Thus, horizontal advection is the main source of nutrients supporting new primary production in the Arctic. Large portions of the ice-free Arctic Ocean are seasonally limited by the lack of available nitrogen (surface nitrate concentrations $<2 \mu \mathrm{M}$, Fig. 10).

Nutrient inputs from the Pacific result in elevated levels of primary production over much of the Chukchi Sea shelf. There, high-nutrient Anadyr Water and Bering Sea Shelf Water fuel some of the highest rates of production in the Arctic. Primary production in these waters has increased dramatically over the last fifteen years (Arrigo and van Dijken, 2011, 2015), likely due to a longer growing season resulting from a longer ice-free period, and to the increased advection of water through Bering Strait as observed from 2001 to 2013 (Woodgate et al., 2012, 2015). Some of this water flows west, where it supports high rates of production on the East Siberian Shelf (Pabi et al., 2008). Most, however, travels northward across the Chukchi Shelf along three pathways (Weingartner et al., 2005) (Fig. 2) that converge on Barrow Canyon, where phytoplankton blooms can persist for most of the summer, resulting in a biological "hot-spot" (Grebmeier et al., 2015). Not all of the water traveling across the Chukchi shelf reaches Barrow Canyon. Some is entrained off the Chukchi Shelf by eddies that inject this high nutrient water into the permanent halocline, where it and associated plankton can be transported far into the Arctic basin (e.g., Mathis et al., 2007; Watanabe et al., 2012).

Advection of nutrient-rich water from the Atlantic Ocean into the southern Barents Sea generates high local rates of primary production (Pabi et al., 2008). These waters originate in the North Atlantic, where winter mixing and convection brings them to the surface. Because they are also warm (Smedsrud et al., 2010), the southern Barents Sea remains ice-free, even in winter, facilitating 

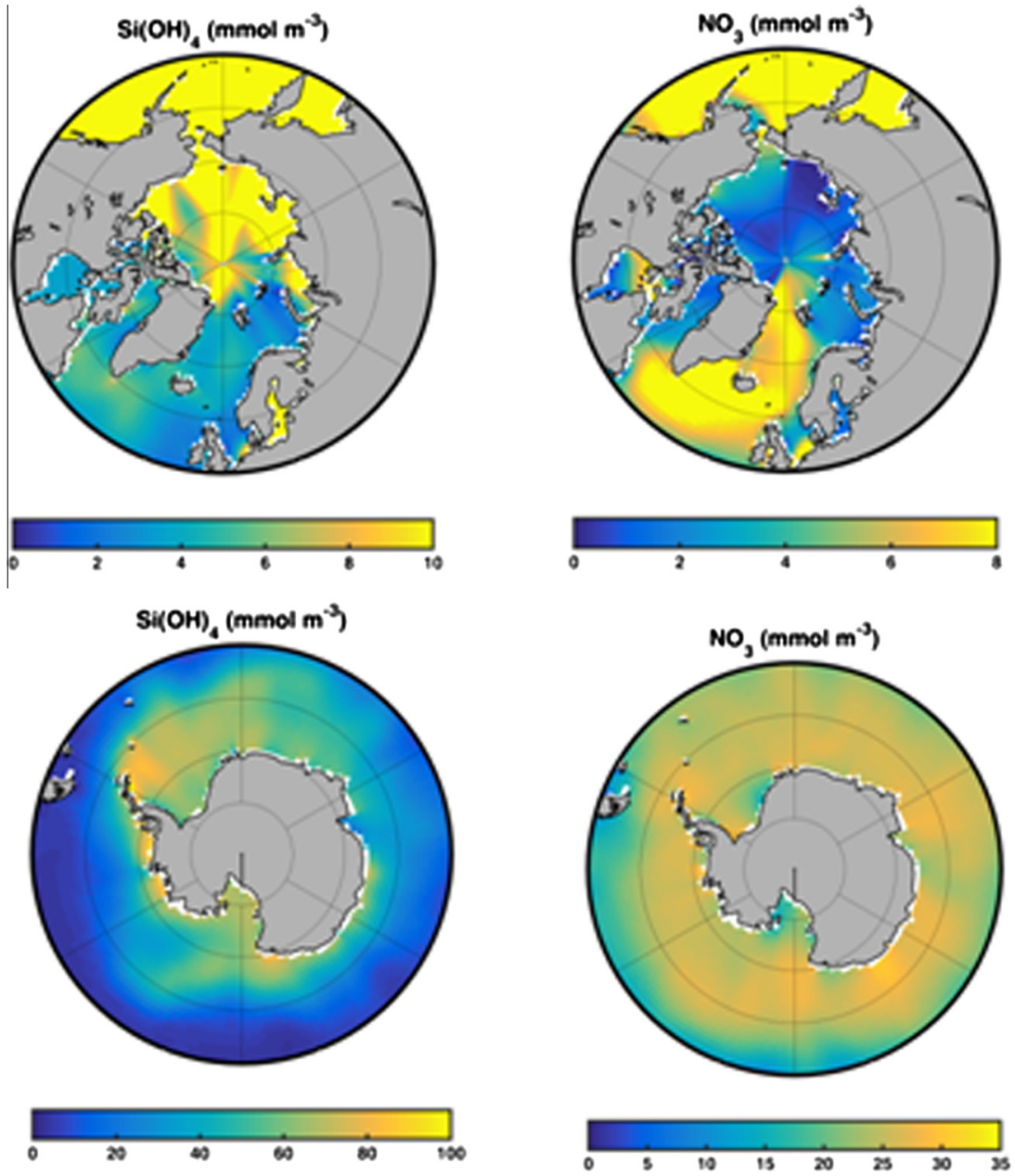

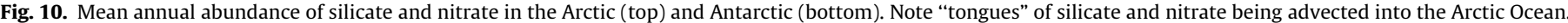
The figures are based on data from the NOAA website: http://www.nodc.noaa.gov/OC5/WOA09/netcdf_data.html.

a long growing season (Hodal and Kristiansen, 2008; Arrigo and Van Dijken, 2011). As a result, the Barents Sea is one of the most productive regions of the Arctic Ocean, both in total primary production and per unit of surface area (Wassmann et al., 2006; Arrigo and Van Dijken, 2011). In the northern Barents Sea, however, advection of water and sea ice from the Arctic Ocean results in cold, low-nutrient conditions, and it is usually ice-covered through the winter, causing a shorter growing season (Loeng, 1991). This contributes to lower primary productivity, typically a half to a third of that in the southern Barents Sea (Loeng and Drinkwater, 2007; Reigstad et al., 2011). Some of the Atlantic Water is advected farther to the north and east via the Barents Sea, where it eventually fuels more modest, but still substantial, rates of primary production in the Laptev and Kara seas.

In the outflow shelves of the Canadian Archipelago and Baffin Bay, rates of production are lower than in the Barents Sea (Pabi et al., 2008; Arrigo and Van Dijken, 2011). These regions receive much of their nutrient supply from the advection of Pacific waters that flow through the Chukchi and Beaufort seas. During this transit, many of the nutrients in surface waters are consumed, reducing potential rates of primary production in Baffin Bay and the Archipelago (Arrigo and Van Dijken, 2015). However, locally enhanced production occurs in areas of upwelling and vertical mixing such as in the North Water Polynya and in the narrow channels of the Canadian Archipelago (Tremblay et al., 2015).

\subsection{Impacts of advection on primary production in the Antarctic}

The primary result of advection with respect to phytoplankton processes is to move nutrient-rich waters (Fig. 10) into areas that have favorable irradiance for phytoplankton growth. In the Southern Ocean, this happens in two important ways. First, strong cyclonic (clockwise) winds drive northward Ekman transport (Thompson and Solomon, 2002), resulting in upwelling (Lovenduski and Gruber, 2005). During positive phases of the Southern Annular Mode, the cyclonic winds intensify and move southward, altering the intensity and position of upwelling as well as the magnitude and location of primary production (Hauck et al. 2013). For example, Montes-Hugo et al. (2009) demonstrated that surface chlorophyll maxima along the Antarctic Peninsula have shifted southward as ice duration has decreased and vertical mixing has increased in the northern Peninsula region. Northward advection in the Bellingshausen, Scotia and northern Weddell seas keeps sea ice at relatively low latitudes and therefore in areas of higher irradiance between fall and spring (Murphy et al., 2007a; Smith and Comiso, 2008). This allows a low level of primary production to continue even during winter, thereby providing a food source for larval and juvenile krill (Kottmeier and Sullivan, 1987; Thorpe et al., 2007).

Secondly, Circumpolar Deep Water, a relatively warm water mass located at a depth of $\sim 200-800 \mathrm{~m}$, is advected onto the 
Antarctic continental shelf through localized upwelling (Clarke et al., 2008; Dinniman et al., 2011). Circumpolar Deep Water brings macro- and micronutrients onto the shelf where they may mix with surface waters and fuel phytoplankton growth. The Southern Boundary of the Antarctic Circumpolar Current, which is the poleward extent of the upwelled Circumpolar Deep Water, and waters to the south, have been identified as areas of enhanced biological productivity (Tynan, 1998; Nicol et al., 2000). In the Ross Sea, Circumpolar Deep Water is advected onto the shelf in troughs between shallow banks (W.O. Smith et al., 2007, 2012a,b, 2014a, 2014b; Dinniman et al., 2011). Although this water mass is located hundreds of meters from the surface when it advects onto the shelf, convective mixing driven by sea-ice formation during winter can bring this water to the surface. In spring, increased concentrations of iron in this convectively-mixed water support large blooms of phytoplankton (Arrigo et al., 1999). The Ross Sea exhibits a great deal of spatial variability in both the presence of Circumpolar Deep Water and the depth of surface mixing (Smith et al., 2014b); therefore, the influence of Circumpolar Deep Water on surface layer processes is also highly variable (McGillicuddy et al., 2015).

Circumpolar Deep Water is also advected via troughs onto the Amundsen Sea shelf, but these waters only infrequently reach the surface layer due to a strong vertical density gradient (Dinniman et al., 2012). However, in some places like Pine Island Bay, this relatively warm water advects beneath floating ice shelves, melting them at their base (Jenkins et al., 2010). This releases iron, and the iron-rich water subsequently rises to the surface near the ice shelf front (Gerringa et al., 2012), stimulating substantial phytoplankton growth and accumulation. Indeed, the highest phytoplankton concentrations in the Southern Ocean are found near the ice shelves of the Amundsen Sea (Arrigo and Van Dijken, 2003; Arrigo et al., 2008, 2015), although the spatial extent of the Amundsen blooms is far less than those in the Ross Sea (Smith et al., 2014b). Advection of modified Circumpolar Deep Water beneath the ice shelves of the Amery Ice Shelf in East Antarctica is associated with ice shelf melting (HerraizBorreguero et al., 2015).

Near the West Antarctic Peninsula, currents impinging on the edge of the continental shelf upwell Circumpolar Deep Water (Clarke et al., 2008), supporting phytoplankton production in such areas as the Marguerite Trough (Prézelin et al., 2000; Dinniman et al., 2011). As in the Amundsen Sea, these waters often remain at sub-euphotic depths, but bathymetric features force Circumpolar Deep Water into the surface layer and stimulate diatom blooms (Prézelin et al., 2000). The episodic nature of these blooms contributes to the spatial and temporal mosaic in productivity on the shelf.

Currents passing around South Georgia, Crozet, the Kerguelen Plateau, and other islands in the Southern Ocean result in turbulence, resuspension of sediments, and upwelling of micronutrients that support extensive blooms downstream of the islands. The signature of the bloom generated around South Georgia extends downstream over $2700 \mathrm{~km}$ to the east in the Antarctic Circumpolar Current (Korb et al., 2004; Murphy et al., 2007a). On the Kerguelen Plateau, natural iron fertilization caused by resuspension of sediments as the Antarctic Circumpolar Current flows past Kerguelen Island fuels one of the largest phytoplankton blooms in the high-nutrient low-chlorophyll Southern Ocean (Pollard et al., 2009; Quéguinér, 2013; Blain et al., 2015).

\section{Benthos}

Benthic organisms are strongly affected by advective processes. Their habitats and food supplies are determined by wind and sur- face currents advecting sea ice, open-ocean currents redistributing organic material in the pelagic zone, and near-bottom currents interacting with bottom topography. The deep-sea floor is thought to be food-limited in many areas. Advective processes impact the distribution/redistribution of organic carbon fixed within the sea ice or surface waters, and therefore, influence the coupling of pelagic and benthic processes, affecting benthic community structure and function. In general, strong tidal or residual bottom currents result in dominance by suspension-feeding epifauna where horizontal advection/resuspension of particulate organic material provides a reliable food source. In contrast, deposit feeders are most abundant in deeper trough areas where depositional processes dominate. These physical-geological-biological interactions are fundamental in structuring communities in both the Arctic (Piepenburg, 1988; Ambrose and Renaud, 1995; Piepenburg et al., 1995; Cochrane et al., 2009; Kędra et al., 2013) and the Antarctic (Brey and Gerdes, 1997; Gili et al., 2001, 2006). Because of these factors, the Antarctic presents a community mainly constituted by epifauna (Arntz et al., 1994; Sirenko, 2009), whereas in the Arctic, the infauna is the main constituent of benthic communities (Sirenko, 2009; Piepenburg et al., 2011). Many consequences of advective processes are similar in the Arctic and Antarctic, and below we stress examples where the relative importance of the processes appears to vary regionally.

\subsection{Impacts of advection on Arctic benthos}

The advection of organic material from the sub-Arctic into the Arctic Basin impacts the benthos differently in the Atlantic and the Pacific regions. In general, a low proportion of the primary production in the northern Bering and Chukchi Seas is consumed in the water column (Campbell et al., 2009), leaving a considerable fraction for vertical or horizontal transport (Kędra et al., 2015). Pelagic organic matter, including living Bering Sea plankton, is advected through Bering Strait into the Chukchi Sea. The ultimate distribution of this material is then controlled by bathymetricallysteered currents, resulting in deposition centers in depressions on the shelf (Dunton et al., 2005; Grebmeier et al., 2006a, 2015) and off the Arctic shelf (Clough et al., 2005; Grebmeier et al., 2006a). Both sediment properties (organic content) and benthic community structure and function (biomass, carbon remineralization, and bioturbation) reflect these spatial patterns (e.g. Clough et al., 2005; Dunton et al., 2005). This suggests that advection and redistribution of organic matter may lead to an apparent decoupling of pelagic and benthic processes, at least on a local scale. However, tight pelagic-benthic coupling has been observed in the Chukchi Sea region (Grebmeier and Barry, 1991; Dunton et al., 2005), indicating that pelagic production can directly influence local benthos.

The advection of organic matter from the sub-Arctic Atlantic to the Arctic benthos is of less importance than in the Pacific sector. The high biomass of potential grazers, the long distance that material from the Norwegian Sea must travel before entering the Barents Sea, and the deep water it traverses $(>2000 \mathrm{~m}$ ) all limit the amount that remains available for sea-floor communities. Advected organic matter and nutrients contribute to in situ pelagic production and food-web interactions, which are linked with the Arctic benthos. Strong links between local sea-ice algae and phytoplankton and benthic processes occur, e.g., in the Barents Sea (Tamelander et al., 2006; Renaud et al., 2008; Morata and Renaud, 2008; Cochrane et al., 2009) and on the Greenland shelf (Ambrose and Renaud, 1995; Hobson et al., 1995; Piepenburg et al., 1997), suggesting a relatively low importance of advected carbon for those benthic communities.

Whereas organic carbon subsidy from the Norwegian and Bering seas per se may be of variable significance to Arctic benthic communities, advection of reproductive organisms from sub- 
Arctic to Arctic regions is clearly important in both. It is the main source of spreading of boreal taxa with subsequent reductions in Arctic fauna, which largely occurs in inflow shelf regions (Berge et al., 2005; Grebmeier, 2012; Renaud et al., 2015). This spreading may be through direct transport of benthic organisms by the currents or indirectly through current-driven hydrographic changes that provide suitable habitat to allow certain benthic organisms to expand their geographic boundaries, or both. Expansion of sub-Arctic species occurred in the Barents Sea and around Spitsbergen during the early to mid 20th Century due to an increase in the warm Atlantic Current inflows (Brooks, 1938). These increased flows subsequently resulted in an expansion of boreal benthic species northward and eastward, and a retreat of Arctic species (Blacker, 1957, 1965; Cushing, 1982). Such major expansions and contractions of benthic organisms tend to occur over long time scales (e.g., decadal or multidecadal). Some of the species recently observed to have expanded (e.g., blue mussels, Mytilus edulis) can be exploited by other taxa, while other invasive species such as king crab, Paralithodes camtschaticus, and snow crab, Chionoecetes opilio, have strong top-down impacts on the existing community (Alsvåg et al., 2009; Oug et al., 2011). These examples suggest that there is a large potential for impact of expanding taxa on Arctic food webs (Christiansen et al., 2015). It is important to note that advection as a vector for species range expansion on both sides of the Arctic has been considered primarily to be from south to north, despite significant inputs of Arctic waters into the Atlantic.

Arctic rivers bring considerable freshwater, sediments, and terrestrial organic matter onto the interior shelves. This organic matter appears to be largely refractory relative to pelagic primary production, but dominates the sedimentary organic content of alluvial plains, and may be an important carbon source for food webs (e.g., the lagoon system of the Alaskan Beaufort Sea shelf (Dunton et al., 2006) and the near-shore regions of the Laptev Sea (Schmid et al., 2006)). Advection also has strong impacts on shelf-canyon systems that steer organic matter, produced or initially deposited on the shelves, into the deep basin. Barrow Canyon, for example, exhibits an enriched benthic community structure and function (Clough et al., 2005; Dunton et al., 2006; Grebmeier et al., 2006a, 2015) due to its role in focusing transport of organic material (e.g., Moran et al., 2005).

\subsection{Impacts of advection on the Antarctic benthos}

Antarctic benthos often dwells on relatively deep (>500 m) continental shelves that receive pulses of sedimentary organic matter during the spring-summer season when material released from melting sea ice and the seasonal phytoplankton bloom rapidly sinks to depth (von Bodungen et al., 1986; Dunbar et al., 1989, 1998; Bathmann et al., 1991; Wefer and Fischer, 1991; Riebesell et al., 1991; Park et al., 1999; Lizotte, 2001; Palanques et al., 2002; Isla et al., 2009). These pulses provide the major organic flux to the benthos, although the temporal relationship of flux to biomass accumulation can vary (Smith et al., 2008). The organic matter can, in some locations, accumulate as green mats on the seabed (Gutt et al., 1998; Smith and DeMaster, 2008; C.R. Smith et al., 2012), providing a high quality food supply for benthos during the autumn and winter months (Mincks et al., 2005; Isla et al., 2006b) when the pelagic input of organic matter to the benthic realm is negligible (Wefer and Fischer, 1991; Dower et al., 1996; Palanques et al., 2002; Isla et al., 2006b). During this time, the benthos continues to feed and metabolize (Barnes and Clarke, 1995; McClintic et al., 2008), at least in part due to the near-bottom currents that resuspend and redistribute material (Gardner et al., 2000; McClintic et al., 2008; Isla et al., 2006a).
Winds and currents advect suspended particles from surface production for great distances (hundreds of $\mathrm{km}$ ), determining the place where pelagic organic matter will reach the benthic realm (Dunbar et al., 1998; Diekmann and Kuhn, 1999; Isla et al., 2004; Holland and Kwok, 2012). Thus, advection acts to separate, in both space and time, the source of organic matter from its location on the sea floor (Smith et al., 2006). These horizontal fluxes can maintain macro-benthic life in unproductive environments such as those under large, floating ice shelves (e.g., the Larsen and Ross ice shelves), where organic matter is supplied only by lateral advection (Sañé et al., 2011, 2012).

Decoupling between production and deposition areas can make the habitat characteristics of the sea floor more important in shaping benthic community patterns than upper ocean processes (Barry et al., 2003). The deposition site of the organic material determines the spatial distribution and composition of Antarctic benthic communities (Orejas et al., 2003; Thrush et al., 2006; Thatje et al., 2008). The redistribution of pelagic production, together with physical factors (e.g., iceberg scouring, anchor ice, resuspension) and the location of polynyas, appear to be the main factors controlling spatial variability in diversity patterns along the western coast of the Ross Sea (Barry et al., 2003; Thrush et al., 2006). As in the Arctic, the transport of reproductive forms by currents is likely an important factor in determining the species composition of the Antarctic shelf benthos. The invasion of the king crab (Lithodes santolla) in Antarctica may well have been due to advection of larvae through the Antarctic Circumpolar Current to the shelf regions (Thatje and Fuentes, 2003); alternatively, Griffiths et al. (2013) suggest that these are relict populations and not new arrivals.

\section{Zooplankton}

Current flow and direction leads to dispersal or retention of zooplankton, which impacts scales of connectivity and, therefore, zooplankton dynamics, genetic diversity, biogeography, and resilience to human exploitation (Huntley and Niiler, 1995). Knowledge of the scales and links between physical and biological processes impacting zooplankton in both polar ecosystems is critical, as the dominant species are relatively long lived (copepods 1-4 years, Arctic euphausiid species 3-4 years, Antarctic euphausiids $>5$ years, and possibly as many as 9 years) (Ikeda and Thomas, 1987; Murphy et al., 1998; Falk-Petersen et al., 2009). These zooplankton are important grazers on microplankton and ice algae, and form important couplings to the upper trophic levels.

\subsection{Impacts of advection on zooplankton in the Arctic}

The Arctic Ocean contains a mix of Arctic endemic species and boreal species of either Atlantic or Pacific origin that are advected to the Arctic Ocean by the inflow currents from the Atlantic and Pacific or the Arctic shelf (Kosobokova and Hopcroft, 2010; Kosobokova et al., 2011). The advection of zooplankton biomass through the Atlantic gateways is 2-3 times higher than through the Pacific gateway, a difference that is driven by the large volume of inflows from the Atlantic (Wassmann et al., 2015).

In the North Pacific, large oceanic copepods, such as Neocalanus spp., dominate mesozooplankton biomass in the waters of the shelf-slope of the eastern Bering Sea and Aleutian Basin, along with several species of euphausiids. On-shelf fluxes of this water along the eastern shelf-slope supply a major component of the zooplankton biomass available in the Outer Shelf Domain of the eastern Bering Sea (Gibson et al., 2013). Some of this water flows northwestward as the Bering Slope Current and enters the Gulf of Anadyr, eventually passing northward through Anadyr Strait between Siberia and St. Lawrence Island (Figs. 1 and 2). In spring, 
the mixture of Anadyr Water and Bering Shelf Water that enters the Chukchi Sea is depleted of large copepods because of the long transit time from the Bering Sea Basin, where they overwinter at depth (Springer et al., 1989; Hopcroft et al., 2010; Hunt et al., 2013). However, by mid-summer the Anadyr Water carries an estimated zooplankton biomass of $175-205 \times 10^{3}$ tons dry mass $\mathrm{d}^{-1}$ (Springer et al., 1989) northward through the Chirikov Basin and into the Chukchi Sea as far as Barrow Canyon (Berline et al., 2008; Ashjian et al., 2010). On the eastern Bering Sea shelf, flows are weaker in the mean and are less persistent in direction (Danielson et al., 2012b). Nevertheless, considerable zooplankton biomass is transported north in Bering Shelf Water around St. Lawrence Island into the Chukchi Sea (Springer et al., 1989; Piatt and Springer, 2003; Hopcroft et al., 2010; Wassmann et al., 2015; Figs. 1 and 2).

Although southward flows through Bering Strait are generally not strong or prolonged, when they occur, they provide the potential for advecting Arctic zooplankton or fish eggs and larvae southward into the Bering Sea (e.g., Pinchuk et al., 2013). Passively drifting organisms that remain near the surface may have a stronger propensity to be carried southward through Bering Strait because the surface waters are more strongly influenced by wind.

In the Atlantic sector of the Arctic, there are major fluxes of zooplankton from the Norwegian Sea to the Barents Sea, and to the Arctic Ocean via Fram Strait (Fig. 3). The most important of the advected zooplankton are euphausiids and copepods, especially Calanus finmarchicus, which is a major food source for juvenile Atlantic cod (Gadus morhua), herring (Clupea harengus) and capelin (Mallotus villosus) in the southern Barents Sea (Dalpadado and Bogstad, 2004; Pedersen and Fossheim, 2008; Dalpadado and Mowbray, 2013; Hunt et al., 2013). The estimated $8 \times 10^{6}$ tons of zooplankton advected into the Barents Sea annually is equivalent to about one third of the annual zooplankton production in the southern Barents Sea (Dalpadado et al., 2012a; Dalpadado and Mowbray, 2013).

Zooplankton are advected into the Arctic Ocean through eastern Fram Strait north of Svalbard and around the Yermak Plateau, through the northern Kara Sea region via the eastern St. Anna Trough, and through Bering Strait following three main pathways across the Chukchi shelf (Wassmann et al., 2015). An allochthonous assemblage of mostly Atlantic zooplankton species dominates the zooplankton in the Amundsen and Nansen basins and zooplankton biomass is highest in the core of the Atlantic inflow along the Eurasian continental margin (Kosobokova and Hirche, 2000, 2009; Hirche and Kosobokova, 2007; Kosobokova et al., 2011). The biomass and proportion of Atlantic species decreases rapidly towards the interior shelf seas and the central basins (Kosobokova and Hirche, 2000, 2009; Wassmann et al., 2015). Pacific expatriates are largely restricted to the Canada and Makarov Basins (Kosobokova and Hirche, 2000; Nelson et al., 2009).

Little is known of the actual fate of Atlantic expatriates in the Arctic Ocean. For example, the Atlantic C. finmarchicus can be transported as far as the Makarov Basin, but not to the Canada Basin (Kosobokova and Hirche, 2009; Kosobokova et al., 2011). It is unlikely that boreal zooplankton species are able to reproduce on the Arctic shelf due to the low water temperatures and the short growing season (Jaschnov, 1970; Tande et al., 1985; Slagstad et al., 2011; Wassmann et al., 2015). Whether boreal species like $C$. finmarchicus can complete their life cycle in the Arctic Ocean is still unknown (Wassmann et al., 2015). A modeling study by Ji et al. (2012) concluded that, even if water temperatures increase by $2{ }^{\circ} \mathrm{C}$ or the growth season is prolonged by 2 weeks, conditions would not become favorable enough to allow $C$. finmarchicus to intrude farther north and colonize the Arctic Ocean.

Arctic zooplankton, including $C$. glacialis and $C$. hyperboreus, are advected south from the Arctic Ocean into the northern Barents
Sea, where they are an important component of the diets of fish and seabirds (Falk-Petersen et al., 2007; Dalpadado and Mowbray, 2013). Some of this water eventually passes around the southern tip of Spitsbergen as the Sørkapp Current, which then turns northward along the west coast of Spitsbergen (Fig. 3). Arctic zooplankton are also carried south through the west side of Fram Strait in the East Greenland Current (Hirche, 1991; Fig. 3).

\subsection{Impacts of advection on zooplankton in the Antarctic}

Advection of zooplankton is recognized as an important characteristic of Southern Ocean ecosystems and is central to our understanding of their population structure and ecological function (Hofmann and Murphy, 2004). The strong annular currents disperse zooplankton widely around the Antarctic. In contrast, the strong temperature gradients of the Antarctic Polar Front appear to be an effective physiological, albeit leaky, barrier to physical exchange of pelagic zooplankton between sub-Antarctic and Antarctic ecosystems (Patarnello et al., 1996). Thus, the Antarctic zooplankton fauna has evolved largely in isolation from that of the sub-Antarctic.

In the Antarctic, horizontal advection controls whether zooplankton reside in food-poor (e.g. northern zone of the Antarctic Circumpolar Current) or in food-rich areas (e.g., waters south of the Southern Boundary of the Antarctic Circumpolar Current, including coastal shelves, ice edge-blooms, frontal zones). The Southern Boundary of the Antarctic Circumpolar Current is leaky and there is extensive exchange, particularly from south to north, through oceanographic flows, eddy transfers and sea-ice drift (Falco and Zambianchi, 2011). In addition, different types of mesoscale circulation features (i.e. eddies, fronts) govern the residence time of zooplankton in a given food regime, thereby exerting control on zooplankton dynamics (Huntley and Niiler, 1995), and mesoscale gyres are an important influence on the distribution of krill around the coast of East Antarctica (Nicol et al., 2000). It has also been suggested that such mesoscale features may be important in the circumpolar distribution of krill (Nicol, 2006).

The highest zooplankton biomass in coastal regions occurs in waters west of the Antarctic Peninsula, followed by an order of magnitude lower biomass in waters over the Weddell and Ross Sea continental shelves, and another order magnitude lower over all other shelves (Deibel and Daly, 2007). The variation in biomass is likely due to differences in bottom-up processes (recruitment from off-shelf areas, ice cover, primary production) and topdown predation in different regions and seasons (Ainley et al., 2006, 2015; Ainley, 2007; Deibel and Daly, 2007). In East Antarctica, krill populations increase in years when sea-ice cover expands and extends farther north (Nicol et al., 2000).

Investigations of zooplankton transport in the Southern Ocean have focused primarily on Antarctic krill, given their importance as a key link in the Antarctic marine food web and as the focus of a commercial fishery (e.g., Hofmann et al., 1998; Murphy et al., 1998, 2004a, 2004b; Hofmann and Murphy, 2004; Fach and Klinck, 2006; Piñones et al., 2013a, 2013b). Krill have a heterogeneous circumpolar distribution, with about $70 \%$ of the stock occurring between 0 and $90^{\circ} \mathrm{W}$, including the open waters of the Antarctic Circumpolar Current in the Atlantic sector (Scotia Sea) and the western side of the Antarctic Peninsula (Atkinson et al., 2008). Krill distributions in the Pacific and Indian Ocean sectors are more closely associated with continental shelves, (e.g., Jarvis et al., 2010; Piñones et al., 2016). Recent results indicate that Antarctic krill are genetically relatively homogeneous at large geographic scales, thus supporting the notion that dispersal by circumpolar currents prevents genetic differentiation in Antarctic zooplankton (Bortolotto et al., 2011). 

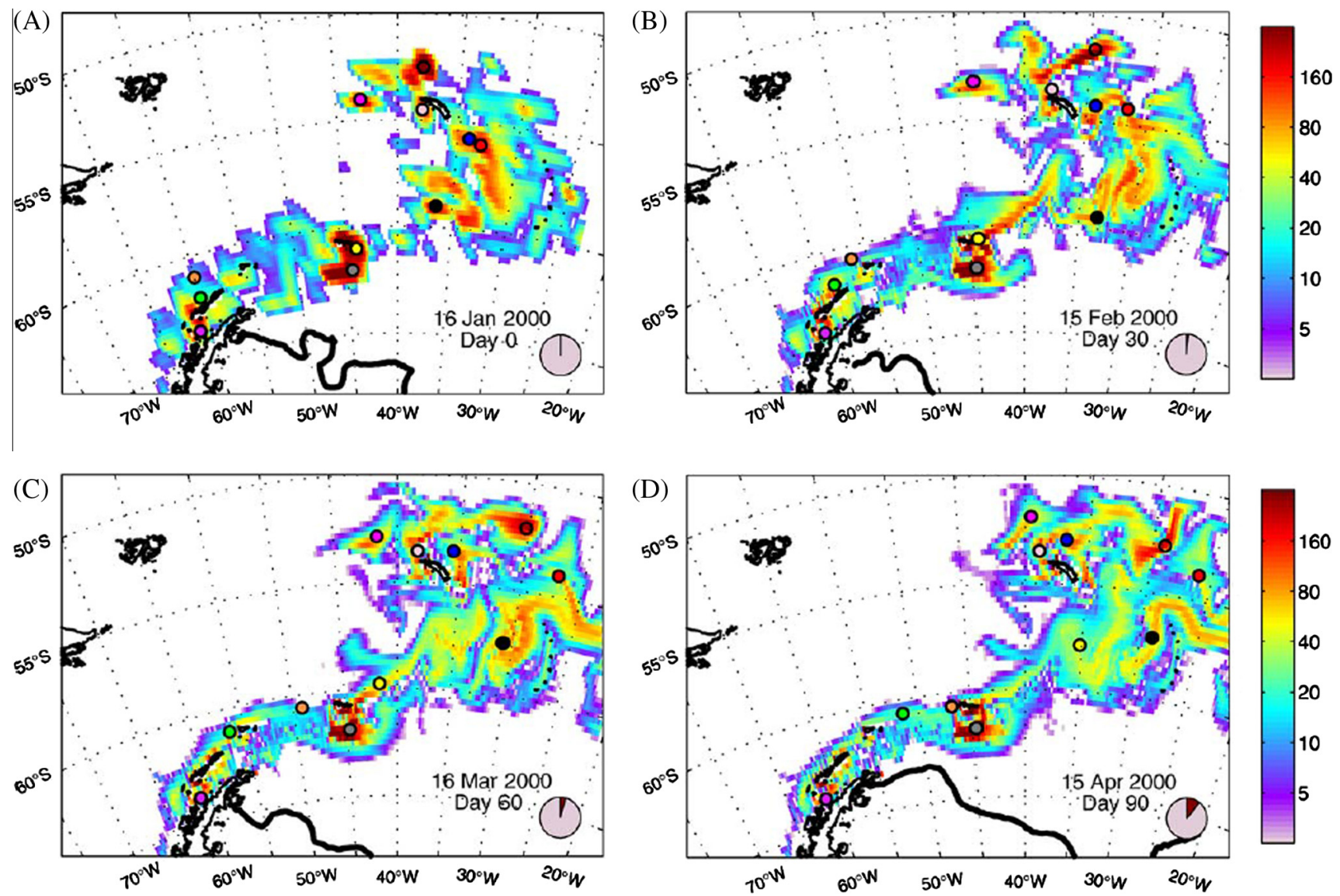

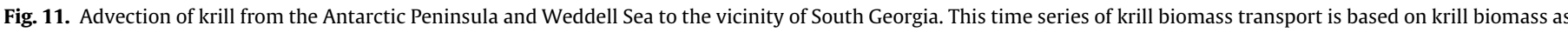

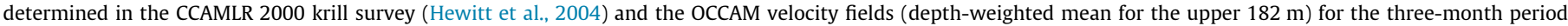

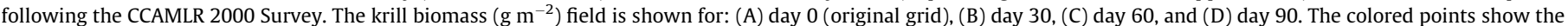

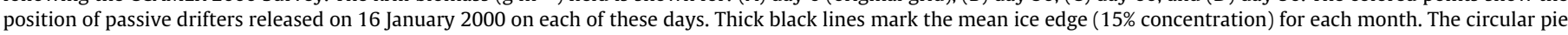
chart shows the proportion of the original krill biomass remaining in the grid area. From: Murphy et al. (2004a), with permission.

The Antarctic Circumpolar Current provides a connection between many regions of the Southern Ocean, including open ocean and continental shelf habitats (Fig. 11). The Antarctic Circumpolar Current also transports krill into regions where there do not appear to be sustainable populations. For example, around South Georgia, the combination of few young stages, low growth rates, and the strong eastward flow of the Antarctic Circumpolar Current past the island suggest that krill in this region depend on recruitment from waters to the west (Murphy and Reid, 2001; Murphy et al., 2004a, 2007a; Thorpe et al., 2004, 2007; Tarling et al., 2007) (Fig. 11). Circulation models using simulations of particle trajectories indicate that krill west of the Antarctic Peninsula are an important source population for South Georgia (Hofmann et al., 1998; Murphy et al., 2007a, 2007b). The Antarctic Circumpolar Current flows eastward near the continental shelf break off the Antarctic Peninsula where krill are abundant. Larval and juvenile krill entrained in this current could reach South Georgia in $\leqslant 10$ months (Fach and Klinck, 2006; Fach et al., 2006). Krill originating in the Weddell Sea also could be transported to South Georgia, but over a time scale of about 20 months (Murphy et al., 2004a, 2007a; Thorpe et al., 2007). A krill physiological growth model coupled to a circulation model indicated that krill larvae and juveniles entrained west of the Antarctic Peninsula could grow to the ageand size-classes observed in South Georgia (Fach et al., 2006).

Regional circulation features also impact recruitment dynamics of Antarctic krill. Variability in oceanographic conditions may result in larvae being dispersed from local populations or retained in others. For example, Young et al. (2014) used a high-resolution hydrodynamic model to examine the potential for retention, dispersal and cross shelf exchange around South Georgia, and highlighted the variability of the system with regard to transport and retention of plankton within the region. Likewise, the scale of connectivity and the magnitude of self-recruitment versus remote connectivity were explored by Piñones et al. (2013a) for the Bellingshausen Sea and western Antarctic Peninsula region. During 2002, relatively high abundances of young krill larvae were observed offshore of the shelf break, while much lower densities of late stage larvae were recorded on the inner shelf (Daly, 2004). These findings suggest that remote connectivity from regions in the Bellingshausen Sea with persistently elevated summer chlorophyll might be important for maintaining populations of krill on the Antarctic Peninsula shelf (Marrari et al., 2008). Modeled particles from the Bellingshausen Sea were transported along the Southern Boundary Front of the Antarctic Circumpolar Current to the southern region of the Antarctic Peninsula (Marguerite Bay) in about 120 days, which is approximately the time required for krill eggs to develop into late-stage larvae under summer food conditions (Piñones et al., 2013a). About 23\% of the particles at the shelf break were advected onto the shelf as part of onshore intrusions of Circumpolar Deep Water though Marguerite Trough.

In addition, some areas of the Antarctic Peninsula, including Marguerite Bay, have gyre-like circulations (Smith et al., 1999) that could retain krill on the shelf. The numerical model of Piñones et al. (2013a) showed that particles released in the mid- and inner-shelf regions of Marguerite Bay had low export rates from the shelf $(<20 \%)$, whereas particles released on the outer shelf were more 
frequently advected into the Antarctic Circumpolar Current. Thus, subpopulations of Antarctic Peninsula krill are likely maintained by both local and remote sources of larvae. Remote sources may be particularly important for areas influenced by intrusions of Circumpolar Deep Water (Hofmann and Hüsrevoglu, 2003). Advective processes are also important influences on the distribution of other zooplankton species, including other species of krill and salps (e.g., Loeb and Santora, 2012, 2015).

The importance of advective processes around the Antarctic and sub-Antarctic islands has been extensively demonstrated in the ecosystems around the Prince Edward Archipelago in the southern Indian Ocean, which is located in the flow of the Antarctic Circumpolar Current. Variation in the position of the Subantarctic Front in the vicinity of the archipelago influences both local productivity and advective inputs (Ansorge et al., 1999; Pakhomov and Froneman, 1999b; Pakhomov et al., 2000; Perissinotto et al., 2000). Advection influences transfer of zooplankton (copepods and euphausiids) and micronekton into areas around the islands where they become an important food source for maintaining the large colonies of land-based predators (Pakhomov and Froneman, 1999a, 1999b, 2000; Pakhomov et al., 2000; Allan et al., 2013).

\section{Fish}

The contrasting oceanographic regimes of the Arctic and Antarctic Oceans are major determinants of their fish communities. The Arctic has a more recent evolutionary history than the Antarctic, and the current diversity of fish in the Arctic developed as a result of direct connections to lower latitude sub-Arctic regions, as well as the relative complexity of the Arctic Ocean habitats. The intensification of Northern Hemisphere glaciation that began about 2.9 million years ago reduced sea surface temperatures in the Arctic Ocean to the freezing point (Raymo, 1994), resulting in the elimination of boreal species and the subsequent development of the modern Arctic fish fauna (Briggs, 2008). The opening of the Bering Land Bridge approximately 11 thousand years ago resulted in the great trans-Arctic interchange (Vermeij, 1991), with many families of fishes that had evolved in the North Pacific contributing species to the Atlantic fauna during this period, but few from the Atlantic contributing to the Pacific fauna.

In contrast, the Antarctic fish fauna has been isolated for much longer (>20 million years; Brey et al., 1994) and not subject to such profound changes in geomorphology. This has resulted in a high degree of endemism on the continental shelf and upper slope (88\%, Eastman, 2005), with $85 \%$ of the fish fauna belonging to five families of notothenioids (ice-fishes) that arose in Antarctica and two families (Liparididae, Zoarcidae) that invaded from the North Pacific (Briggs and Bowen, 2012). The Antarctic Circumpolar Current isolates the Antarctic fish fauna from more temperate waters and connects fish populations around the Antarctic, as evident in the lack of population structure in four notothenioids (Janko et al., 2007). One of the major evolutionary outcomes of the isolation of the Southern Ocean is that there are few epipelagic oceanic species (Knox, 2007). Mesopelagic species are present throughout much of the Southern Ocean and can have an important role in regional epipelagic food webs (Ainley et al., 1992; Eastman, 1993; Piatkowski et al., 1994; Pakhomov et al., 1996; Duhamel, 1998; Duhamel et al., 2000; Pusch et al., 2004; Collins et al., 2012; Murphy et al., 2013).

\subsection{Impacts of advection on fish populations in the Arctic}

Advective exchanges between the sub-Arctic and Arctic play a dominant role in the life-cycle of fish in the sub-Arctic to Arctic transition zone. The eggs and/or larvae of many sub-Arctic and Arctic fish species are planktonic for several months and may be carried in the prevailing currents to suitable larval feeding areas, often associated with the receding ice edge. Retention or dispersion of larvae from spawning areas is generally recognized as a key determinant of recruitment success (Shelton and Hutchings, 1982), and climate-driven changes in larval dispersal have been identified as one of the major unknowns in studying these effects on fish (Petitgas et al., 2013).

Arctic cod (Boreogadus saida) is the most abundant fish species in the Arctic and has a circumpolar distribution that approximately matches the winter extent of sea ice (Svetividov, 1948; Andriashev et al., 1980). Eggs are spawned and hatch under the ice (Rass, 1968), and larvae are often found under the ice near river plumes, which they may use as a thermal refuge during winter (Bouchard and Fortier, 2011), and as a feeding habitat during spring (Fortier et al., 1996). Larvae remain in the upper water column until the end of their first summer, before descending to deeper layers or to the bottom (Geoffroy et al., 2011, 2016). However, juveniles may also remain pelagic or associated with sea ice (Lønne and Gulliksen, 1989; Ajiad et al., 2011; Gradinger and Bluhm, 2004; David et al., 2016). Advection of water masses contributes to the spreading of eggs and larvae in pelagic water masses, e.g., in a main part of the Barents Sea and throughout the Canadian Arctic Archipelago (Bradstreet et al., 1986; Ajiad et al., 2011). Polar cod associated with sea ice are transported from the Arctic Ocean to the marginal seas, where they are released when the ice melts (Hop and Gjøsæter, 2013).

In the southeastern Bering Sea, major gadoid and flatfish stocks spawn along the slope or on the outer portions of the shelf, with larvae being advected onto the shelf where they feed on zooplankton in stratified waters before settling in demersal habitats as juveniles. Settlement typically occurs long before larvae or juveniles are advected to the northern Bering Sea or Chukchi Sea because current patterns on the shelf, in particular in the middle shelf region, tend to favor retention over long-distance dispersal (Parada et al., 2010; Richar et al., 2014; Petrik et al., 2015, 2016). Nevertheless, interannual variability in advection of larvae towards or away from suitable nursery areas affects the recruitment of flatfishes and Pacific cod (Gadus macrocephalus) (Wilderbuer et al., 2002, 2013; Duffy-Anderson et al., 2013; Vestfals et al., 2014). Although the Bering Sea is a major source of nutrients and plankton for the Chukchi Sea, available ichthyoplankton data suggest a discontinuous distribution of eggs and larvae in the northern Bering Sea and Chukchi Sea for most fish species, providing little evidence that fish eggs or larvae spawned in the Bering Sea are advected into the Chukchi Sea (Morgan Busby, NOAA, Seattle, pers. comm.). However, the presence of early life stages of walleye pollock (Gadus chalcogrammus), the most abundant commercial species on the Bering Sea shelf, in both the Chukchi and Beaufort seas (Logerwell et al., 2015) suggests they were advected through Bering Strait because temperatures in the Arctic are believed to be too cold to support spawning of pollock (Hollowed et al., 2013).

Major fish stocks in the Northeast Atlantic, including Atlantic cod, Atlantic herring and haddock (Melanogrammus aeglefinus), spawn off western Norway and their eggs and larvae are advected north to the Barents Sea where they feed on zooplankton. Recruitment success of herring appears to be enhanced when stronger advection more rapidly transports larvae to their nursery areas in the Barents Sea (Vikebø et al., 2010). Recent increases in the heat flux into the Barents Sea have been associated with increasing abundances and geographic expansions of capelin, Atlantic cod, haddock and mackerel (Scomber scombrus) in the Barents Sea (Dalpadado et al., 2012b; Kjesbu et al., 2014; Landa et al., 2014) and farther north to Svalbard and the Arctic Ocean (Renaud et al., 2012; Nahrgang et al., 2014; Berge et al., 2015). Conversely, the 
population of Arctic cod (B. saida) has decreased in the Barents Sea over the last 10 years (Havforskningsrapporten, 2015), likely because of increased competition and predation by boreal species (Renaud et al., 2012; Hop and Gjøsæter, 2013). However, the core distribution area also seems to have shifted towards the northeast, where the population estimates are more uncertain (Havforskningsrapporten, 2015).

Changes in larval advection have also been linked to changes in the abundance of capelin and Atlantic cod around Greenland. The East Greenland Current has been an important feeding ground for the Icelandic capelin stocks in recent years, where they feed on advected zooplankton (Pálsson et al., 2012). The Irminger, East Greenland and West Greenland currents (Figs. 1 and 3) also advect larval Atlantic cod, capelin, and other species originating from spawning areas off East Greenland and Iceland around the tip of Greenland to nursery areas off West Greenland (Storr-Paulsen et al., 2004; Pedersen et al., 2005). Variability in the advection of larvae along this pathway has contributed to large variations in the abundance and catches of Atlantic cod on multi-decadal time scales (Drinkwater, 2006).

\subsection{Impacts of advection on fish populations in the Antarctic}

In the Southern Ocean, the potential for passive advection of fish eggs and larvae from the north is reduced because of little southward flow of surface waters across the Polar Front. With much cooler waters to the south of the Polar Front, physiological constraints strongly limit the potential for southward movement by large migratory fish species such as tuna. However, other factors are also likely to be important in limiting the potential for pelagic fish species to survive in the Southern Ocean, including its: temperature, marked seasonality, great depth, relatively small shelf area, and the patchy productivity and food supply there (Hempel, 1985; Eastman, 1993; Knox, 1994; Murphy et al., 2007a).

Most Southern Ocean fish species are demersal or semidemersal, occurring in relatively restricted shelf regions around the continental Antarctic and sub-Antarctic islands (Kock, 1992, 1994; Eastman, 1993). The direct role of advection on some of these species, which have short larval phases, is probably quite limited. Some species, such as the Scotia Sea icefish (Chaenocephalus aceratus) and the mackerel icefish (Champsocephalus gunnarii), however, have larval and juvenile stages that are pelagic and can extend over several months (Damerau et al., 2012). This allows the potential for transport over significant distances during their development (Ashford et al., 2010; Damerau et al., 2012).

The Antarctic Coastal Current and the Antarctic Circumpolar Current connect icefish populations along the continental shelf and between Southern Ocean islands, although there is some evidence for population structure (Ashford and Jones, 2007; Ashford et al., 2010, 2012b; Young et al., 2012, 2015). For example, icefish populations around the Antarctic Peninsula supply larvae that can be transported in the Antarctic Circumpolar Current to the north and east where they recruit into populations around the South Orkney Islands and South Georgia (Ashford et al., 2010; Damerau et al., 2012). The analyses available so far suggest a high degree of variability in connectivity.

A few ecologically important fish species also use a more pelagic habitat in coastal areas. In southern areas of the continental shelf that are associated with sea ice for most of the year, such as the southern Antarctic Peninsula and the Ross Sea, the Antarctic silverfish (Pleuragramma antarcticum) is an important species in food webs (Ducklow et al., 2007; K.L. Smith et al., 2007; Nicol et al., 2008a, 2008b; Heerah et al., 2013). Its early larval and juvenile stages are associated with the sea ice (La Mesa and Eastman, 2012; Vacchi et al., 2012). Thus, the movement of sea ice is likely to generate horizontal transport that will affect these distributions.
Another species of particular note is the Antarctic toothfish (Dissostichus mawsoni), which is a large species with a maximum length greater than $2 \mathrm{~m}$, weights over $200 \mathrm{~kg}$, and is the target of a commercial fishery (Collins et al., 2010; Ashford et al., 2012a, 2012b). Biochemical analyses and model studies have suggested regional ocean circulation facilitates the movement of adult Antarctic toothfish along the shelf slope into the banks and ridges of the Pacific-Antarctic Ridge where they spawn; their pelagic eggs and early life stages are transported in the flow back into the coastal regions of the Ross Sea (Ashford et al., 2012a; Hanchet et al., 2015). The ecological importance of mesopelagic species, and particularly myctophids, in Southern Ocean food webs is being increasingly recognized (Ainley et al., 1992; Pakhomov et al., 1996; Duhamel et al., 2000; Pusch et al., 2004; Collins et al., 2012). Although more analyses are required of both controls on distribution and role in food webs, a number of studies indicate that advective processes are important in bringing mesopelagic species into coastal and shelf regions, making them more available to land-based predators (Pakhomov and Froneman, 1999a; Ducklow et al., 2007; Murphy et al., 2013).

Krill are an important component of the diet of various fish species at South Georgia and particularly for the commercially important Patagonian toothfish (D. eleginoides) (Belchier and Collins, 2008). When there are few krill, the condition of mackerel icefish is negatively affected and growth rates are reduced (Everson et al., 1997, 1999). In sub-Antarctic regions, Antarctic krill are less important, and the advection of zooplankton and myctophid fish into shelf areas helps maintain local food webs (Perissinotto and McQuaid, 1992; Pakhomov and Froneman, 1999b).

\section{Impacts of advection on seabirds and marine mammals}

There are three principal ways in which oceanic advection influences seabirds and marine mammals: by transporting prey to the vicinity of colonies located far from where prey are being recruited, by concentrating planktonic prey to a sufficiently high density to be harvested efficiently, and through the effects of advection on the availability and distribution of sea ice, and thus access to prey. The direction of basin-scale ocean currents influences the distributions of seabird colonies. In the Northern Hemisphere, the species composition of seabird colonies is offset latitudinally, with the northernmost colonies of a given species located farther north on the eastern side of ocean basins, a reflection of the warm currents that flow northward on the eastern sides of the Atlantic and Pacific, while cold currents flow southward in the west (Hunt and Nettleship, 1988). In contrast, in the Southern Hemisphere, seabird colonies have an annular organization, with similar species found at similar latitudes around the continent, again reflecting the organization of the major current systems.

\subsection{Advection and the location of seabird colonies and pinniped rookeries}

In both the Northern and Southern Hemispheres, many colonies or rookeries of planktivorous seabirds and pinnipeds are located near where currents advect or concentrate zooplankton. This is particularly important because, while provisioning offspring, breeding birds and pinnipeds are constrained to forage close to their breeding sites. For example, in the North Atlantic, on the south and west coasts of Spitsbergen and the eastern shores of Greenland, advection supports millions of nesting little auks (Alle alle) that forage on large, lipid-rich, Arctic copepods, their preferred prey (Pedersen and Falk, 2001; Karnovsky et al., 2003, 2010; Harding et al., 2009). 
Zooplankton advected from sub-Arctic regions of the Pacific to the Arctic shelves constitute an essential source of energy for Arctic seabirds and marine mammals. This advected zooplankton supplements, and in some cases dominates, the local zooplankton community and its secondary production, and may provide prey before local production has developed sufficiently to support planktivores. Thus, much of the biomass of large, lipid-rich copepods and euphausiids available to seabirds in the Chirikov Basin and Bering Strait is advected in Anadyr Water from the deep waters of the Bering Sea (Springer et al., 1989, 1996; Hunt et al., 2013). In the Chukchi Sea in summer, zooplankton advected in Anadyr and Bering Sea Water support high numbers of postbreeding seabirds (Springer et al., 1996; Piatt and Springer, 2003; Gall et al., 2013; Hunt et al., 2013). Advection of zooplankton from the Bering Sea in Anadyr Water is also important in providing foraging opportunities for fin (Balaenoptera physalus), humpback (Megaptera novaeanglia), and bowhead (Balaena mysticetus) whales in the western Chukchi Sea (Dahlheim et al., 1980; HeideJørgensen et al., 2013; Hunt et al., 2013), where they feed on euphausiids in the Siberian Coastal Current front (Moore et al., 1995).

In the Bering and Chukchi Seas, benthic "hotspots" are generated through the advection of nutrients to support high levels of primary production, which in turn provides foraging areas for grey whales (Eschrichtius robustus) (Kim and Oliver, 1989). These whales forage on infaunal amphipods that are supported by detritus and phytoplankton advected in the northward flow of Bering Sea and Anadyr waters (Grebmeier et al., 2006b; Highsmith et al., 2006).

In the Southern Ocean, bathymetric steering of the Antarctic Circumpolar Current results in the advection of Antarctic krill to the northern coasts of the South Shetland Islands, the South Orkney Islands, as well as to South Georgia. The resulting concentrations of krill attract not only foraging seabirds and other predators, but also commercial krill fisheries seeking areas of predictable harvest (Hunt et al., 1992; Veit and Hunt, 1992; Trathan et al., 1998). Advection of krill from the Antarctic Peninsula region and Scotia Sea to South Georgia is essential for supporting large populations of seabirds and Antarctic fur seals (Arctocephalus gazelle) (Boyd, 2002), which are specialized for krill consumption. In some years the transport of krill fails, a phenomenon thought to be associated with anomalous atmospheric and oceanic conditions (Murphy et al., 1998, 2007b; Murphy and Reid, 2001; Trathan et al., 2006), and this results in widespread breeding failure and starvation of South Georgia seabirds and fur seals (Murphy et al., 1998; Trathan et al., 2006, 2007).

At a smaller spatial scale, the advection of nutrient-rich Circumpolar Deep Water onto the shelves of the West Antarctic Peninsula helps maintain high levels of primary production and the resultant rich foraging grounds (Prézelin et al., 2000; Clarke et al., 2008; Marrari et al., 2011). Embayments along the west coast of the Peninsula, such as Marguerite Bay, are important foraging areas for whales, pinnipeds, and seabirds (e.g., Friedlaender et al., 2006, 2011). These highly productive local ecosystems support nearby colonies of seabirds and pinnipeds. Likewise, submarine canyons are important for steering the advection of krill and other zooplankton onto the shelf (e.g., Dinniman and Klink, 2004; Ward et al., 2007; Piñones et al., 2011, 2013b), where they become available to predators (Trivelpiece and Fraser, 1995; Schofield et al., 2013). In East Antarctica, odontocete whales take advantage of regions of high productivity associated with physical features (Thiele et al., 2000).

\subsection{Advection and the concentration of prey at fronts}

In both the northern and southern polar regions, seabirds can forage successfully when zooplankton are concentrated at conver- gent fronts and in locations generated by currents impinging upon bathymetric features. Copepods residing in the upper mixed layer are concentrated when a water mass descends below another at a front (e.g., Hunt and Schneider, 1987; Hunt and Harrison, 1990; Hunt et al., 1998). In contrast, euphausiids are concentrated at depth when currents impinge on steep bottom topography and may be carried towards the surface if the upwelling is sufficiently strong (Coyle et al., 1992; Hunt et al., 1998; Russell et al., 1999). Euphausiids advected from the Bering Sea are aggregated and upwelled to the surface northeast of Barrow, Alaska and onto the Beaufort Sea shelf (Berline et al., 2008; Ashjian et al., 2010; Gall et al., 2013). This advection is closely coupled to the direction and magnitude of the winds, and influences the composition, distribution, and availability of zooplankton prey for bowhead whales and seabirds (see also Lowry et al., 2004; Moore and Laidre, 2006).

For some seabirds of the Southern Ocean, including king penguins (Aptenodytes patagonicus) and grey-headed albatrosses (Thalassarche chrysostoma), the fronts of the Antarctic Circumpolar Current are important foraging locales (Rodhouse et al., 1996; Kooyman, 2002; Trathan et al., 2008; Scheffer et al., 2010; Scheffer, 2013). The Antarctic Circumpolar Current transports prey around the continent, and its frontal regions concentrate prey and promote enhanced productivity (Collins et al., 2008, 2012). Seabirds fly or swim to these frontal regions, which may be $500 \mathrm{~km}$ from their nesting habitat (e.g., Weimerskirch et al., 1993; Bost et al., 2009a, 2009b). Wandering albatrosses (Diomedea exulans) make long, looping foraging trips by keeping the wind at least partially behind them (Weimerskirch et al., 2000, 2012). Albatrosses depend on the advective forces of the zonal winds to give them an energetic advantage as they fly to and from their colonies (Rodhouse et al., 1996; Trathan et al., 2008). Crabeater seals in East Antarctica are predictably concentrated where sea ice is present over frontal areas, such as the Antarctic Slope Front and the Southern Boundary of the Antarctic Circumpolar Current (Southwell et al., 2005). Bost et al. (2009a) provide an overview of the importance of fronts to seabirds and marine mammals in the southern oceans.

\subsection{Impacts of advection on sea-ice habitat for seabirds and marine mammals}

Many species of polar seabirds and marine mammals require sea-ice habitat for foraging, resting, and raising young (e.g., Moore and Huntington, 2008; Kovacs et al., 2011; Santora, 2014; Laidre et al., 2015; Delord et al., 2016). Ice floes provide refuge for seabirds and seals from their predators, such as killer whales and leopard seals (e.g., Visser et al., 2008; Pitman and Durban, 2010, 2012). Ice-edge habitats are also important, as that is where ice-using seabirds and marine mammals have access to the airwater interface, and the concentrations of prey associated with the undersurface of the sea ice (Bradstreet and Cross, 1982; Lønne and Gabrielsen, 1992). Upwelling at fronts can force divergence of pack ice, thus providing birds and mammals with access to the air-water interface. In the Amundsen and Bellingshausen seas, seabirds and marine mammals concentrate in the waters above the shelf edge front, where the pack ice is less concentrated (Ainley et al., 1998). When the ice edge is far from a colony site during the breeding season, the production of young by seabirds may be diminished by the need for long commutes to reach locations where prey is accessible (Barbraud and Weimerskirch, 2001; Olivier et al., 2005; Nicol et al., 2008a, 2008b).

\subsubsection{Polynyas as seabird and marine mammal habitats}

Within the sea-ice habitat, polynyas are areas of open water surrounded by sea ice that are kept open either by winds (latent heat polynyas) or by the upwelling of "warm" water (sensible heat 
polynyas). Polynyas provide vital access to the air water interface for seabirds and marine mammals, as well as being areas of high primary and secondary production (e.g., Plötz et al., 1991; Stirling, 1997; Massom et al., 1998; Arrigo and Van Dijken, 2003; Tremblay and Smith, 2007; Arrigo et al., 2015). This access is particularly critical during winter and early spring when access to open water may be severely limited at high latitudes (Gilchrist and Robertson, 2000).

In the Atlantic Arctic, polynyas are of particular importance in regions where cold currents from the central Arctic result in heavy ice cover for much of the year. For example, in northern Baffin Bay, the North Water Polynya opens in early May, due to the advection of ice away from the region (Yao and Tang, 2003). The North Water Polynya is host to high numbers of migrating seabirds in spring and marine mammals during winter and spring. Near Greenland, it supports an early phytoplankton bloom (Mei et al., 2002), and zooplankton are available to seabirds there in early spring (Karnovsky and Hunt, 2002; Tremblay et al., 2006a, 2006b). Millions of little auks nest on the Greenland side of the North Water (Boertman and Mosbech, 1998). On Greenland's northeast coast, the Northeast Water Polynya forms each spring and hosts numerous marine mammals (Born et al., 1997; Wiig et al., 2003). Both the North Water Polynya and the Northeast Water Polynya owe their existence, at least in part, to currents and winds that force the movement of ice to form ice barriers, which then block additional ice drift (Schneider and Budéus, 1994; Minnett et al., 1997; Melling et al., 2001).

Polynyas are also found in the Pacific Arctic, including the Bering and Chukchi seas. Many of these are latent heat polynyas, which form where sea ice is blown away from lee shores as the ice is formed. An important example is the St. Lawrence Island Polynya, where walrus (Odobenus rosmarus divergens) and eider ducks forage in winter on the rich benthic fauna (e.g., Grebmeier, 2012; Lovvorn et al., 2014).

Around much of coastal Antarctica, seabird colonies are most commonly found in the vicinity of productive polynyas (Massom et al., 1998; Ainley, 2002; Arrigo and van Dijken, 2003). Polynyas are of critical importance to Adélie penguins (Pygoscelis adéliae) and emperor penguins (Aptenodytes fosteri) that require access to ice-edge habitats at which they forage during the winter breeding season (Ainley, 2002). Some of the largest Adélie (62\% of known colonies) and emperor penguin colonies are located beside polynyas in the Ross Sea (Smith et al., 2014a), the Palmer Deep, Marguerite Bay, and elsewhere around the continent. The reproductive success of emperor penguins in East Antarctica near Pointe Géologie is strongly influenced by whether strong winds clear fast ice from a region near the colony, thereby decreasing the distance the breeding penguins have to travel to open water (Massom et al., 2009). Throughout the Antarctic, penguin colony size has been shown to be significantly correlated to annual rates of primary production in nearby coastal polynyas (Arrigo et al., 2003). Outside of the breeding season, Antarctic seabirds also forage in polynyas (Ainley et al., 1998; Thiele and Gill, 1999).

Antarctic marine mammals also depend on polynyas. For example, Santora (2014) has documented Antarctic fur seals foraging in polynyas in the vicinity of the Antarctic Peninsula, and Ainley et al. (2007) have found that Antarctic minke whales (B. bonaerensis) concentrate in the nearshore polynyas of the Amundsen and Bellingshausen seas. High levels of primary production in polynyas translates to higher pup production in Weddell seals in the McMurdo Polynya in the Ross Sea, though the mechanistic links that result in this strong linkage are not known (Paterson et al., 2015). Apparently, the seals anticipate the coming high levels of production, which, as the food web develops, may attract the high-trophic-level prey of the seals, the Antarctic toothfish.
9.3.2. Melting of sea ice and the availability of open water to seabirds and marine mammals

Poleward flowing currents transport heat that melts sea ice and thereby provide seabirds and marine mammals access to the airwater interface. For example, the warm offshore branch of the West Greenland Current plays a crucial role in the West Greenland ecosystem. It originates with the Irminger Current off East Greenland, travels south at the edge of the continental slope along the east coast of Greenland around Cape Farewell, then north (Myers et al., 2007), stimulating production, and bringing fish larvae (e.g., Atlantic cod and capelin) from spawning areas off East Greenland and Iceland to the banks off West Greenland (Storr-Paulsen et al., 2004; Pedersen et al., 2005). These in turn attract bowhead whales to the vicinity of Disko Bay between February and May (Laidre et al., 2009; Laidre and Heide-Jørgensen, 2012), and, in summer, foraging humpback whales. The presence of large baleen whales, including fin, humpback, minke (B. acutorostrata), and sei whales ( $B$. borealis) on the West Greenland summer feeding ground is likely related to advective processes that both melt the coastal sea ice and shift capelin and euphausiids onto the shelf (Laidre et al., 2009, 2010). The region supports large colonies of piscivorous seabirds nesting along the southwestern Greenland coast, which also forage on small fish in the open waters. In the eastern North Atlantic Arctic, northward flowing currents bring warm Norwegian Sea Water to the southwestern Barents Sea (Loeng et al., 1997). This warm water sustains a year-round ice-free ocean (Hunt and Megrey, 2005; Hunt et al., 2013), which is available to the high numbers of seabirds that nest on the coasts of Svalbard and northern Norway and winter on the open waters of the southern Barents Sea where they forage for small pelagic fishes and, to a lesser extent, zooplankton (Barrett et al., 2002).

In the Antarctic, the seasonal, serial breakup of fast ice in the bays around the Ross Sea provides open water habitat in which killer whales can seek their prey, which includes both Weddell seals and emperor penguins (Ainley and Ballard, 2012). In the eastern Weddell Sea, the relatively open water associated with the upwelling of warm water over the submarine Maud Rise in the Northeast Weddell Sea is the location of concentrations of seabirds, seals and cetaceans (Comiso and Gordon, 1987; Plötz et al., 1991).

\subsubsection{Advection of the sea-ice habitat}

In the Pacific Arctic, heat transferred by the atmosphere and the northward flowing water from the Bering Sea affects the timing and extent of sea-ice melt (Paquette and Bourke, 1981). The ice melt in spring initially provides open water and leads through which marine mammals can migrate to foraging grounds (Braham et al., 1980; Moore and Laidre, 2006). However, in recent years as the melt-back in summer progresses beyond the shelf edge of the Chukchi and Beaufort seas, ice-dependent species such as walrus and bearded seal (Erignathus barbatus) have lacked ice floes over shallow shelf waters from which they can forage for benthic prey (Jay et al., 2012).

The location of the sea-ice edge is determined by a combination of freezing and melting, wind forcing and currents. When the sea ice is advected over regions of upwelling, such as over the Antarctic Shelf Slope Front, there is enhancement of feeding opportunities for seabirds and marine mammals as the upwelling of nutrients supports phytoplankton growth and subsequent transfers of energy up the food web (Ainley et al., 2007). Also of importance, in upwelling areas, there is divergence within the pack ice, which provides access to the air-water interface. These openings benefit not only seabirds and seals that need to haul out on the sea ice, but also cetaceans that are foraging within the pack ice (Ainley et al., 2007).

Advection of sea ice can also impact seabird populations through its effects on molting habitat on landfast ice. For example, 
emperor penguin and Adélie penguin breeding sites are numerous in the Ross Sea (Trathan et al., 2011) where fast ice is available. Important emperor molt sites are thought to occur where ice floes are constrained to remain in the early summer (D.G. Ainley et al., 2010; D.A. Ainley et al., 2010).

\section{Climate warming, advection, and responses of polar marine ecosystems}

In both the Arctic and the Antarctic, ongoing climate change is altering wind strength and patterns (Marshall et al., 2006; Bracegirdle et al., 2008, 2013) and ocean currents. Also, atmospheric and ocean warming are altering the onset, extent, and duration of seasonal sea ice (Smith et al., 2008, 2014b; Stammerjohn et al., 2008a, 2008b; Markus et al., 2009; Turner and Overland, 2009; Massom and Stammerjohn, 2010; Stroeve et al., 2012; Frey et al., 2015). These changes in the physical system are impacting the biological components of polar oceans (e.g., Clarke et al., 2007; Arrigo and Van Dijken, 2011, 2015; Constable et al., 2014; Gutt et al., 2015). Future decreases in sea-ice cover will have severe impacts on organisms dependent on the sea-ice habitat for some or all of their life activities (Smith et al., 2014a; Laidre et al., 2015). In the ocean many organisms depend on passive transport for dispersal. Dispersal of reproductive forms is especially important as a mechanism for maintaining gene flow between geographically separate segments of a population, as well as a means for colonizing new regions. Current trajectories may change in the future, and components of populations presently connected by dispersal may become isolated. Many ecosystem components are dependent on today's combination of primary production and advection. If these change, we can expect major changes in not only the biomass and productivity of polar ecosystems, but also in their component species and the flow of energy through them. Changing temperatures are also expected to affect the physiology of both poikilothermic and homeothermic organisms. In the examples below, the emphasis is on possible direct effects of advection and their impacts, but also indirect effects through warming and reduced sea ice.

\subsection{Expected changes in atmospheric circulation}

Rising temperatures globally are expected to increase latent heat transport by the atmosphere into the Arctic, which will warm primarily the lower troposphere (Flannery, 1984; Alexeev et al., 2005; Cai, 2005; Held and Soden, 2006; Langen and Alexeev, 2007; Kug et al., 2010). On the other hand, sensible heat transport will decline due to the reduction in the equatorto-pole temperature gradient, and this will more or less offset the latent heat transport increase (Hwang et al., 2011). Poleward shifts of storm tracks in the Northern Hemisphere will contribute to polar warming and the increase in moisture flux into the Arctic (Kug et al., 2010), with possible modifications to the Arctic Oscillation (Choi et al., 2010). The Arctic Polar Vortex will likely weaken, resulting in closer atmospheric connections between the Arctic and sub-Arctic regions, including a likely increase in the frequency of equatorward outbreaks of cold, high-latitude air during winter (Overland et al., 2011; Francis and Vavrus, 2012). Smaller-scale regional changes are also expected, e.g., in the Beaufort Sea region, stronger easterly winds coupled with the near-surface warming will likely promote northward pack ice retreat through both melting and advection via Ekman transport (Wood et al., 2013).

In the Antarctic, future climate change will be driven largely by stratospheric ozone recovery and increasing greenhouse gases. The depletion of the stratospheric ozone since the late 1970s has led to a small cooling over much of the Antarctic continent. However, the first signs of the recovery of the ozone hole have now been confirmed (Solomon et al., 2016), and the concentrations of stratospheric ozone are expected to recover to pre-ozone hole levels in the 2050-2070 time-frame (Newman et al., 2006). Both the recovery of the ozone hole and an increase in greenhouse gas concentrations are projected to result in atmospheric warming, with most models that include both effects indicating a magnitude of warming less than the global mean at the end of the 21 st century (IPCC, 2013). The combination of ozone recovery and anthropogenic warming suggest that the recent positive summertime trends in the Southern Annular Mode will change to negative over the coming decades as the ozone hole recovers (Arblaster et al., 2011; Thompson et al., 2011). This implies the likelihood of a future reduction in the strength and a shift northward of the westerly winds (Thompson and Solomon, 2002; Meijers et al., 2012).

\subsection{Expected changes in ocean circulation}

Under future climate warming, oceanic heat transport into the Arctic by the Atlantic inflow will increase (Koenigk et al., 2013), causing ocean temperatures in the Arctic to continue rising, primarily in the intermediate and deep layers (Koenigk and Brodeau, 2014). It is very likely that the Atlantic Meridional Overturning Circulation will decrease within an estimated mean range of $11-34 \%$ by the end of this century (IPCC, 2013). However, it remains unclear what effect this may have on the volume transport of Atlantic water to the Arctic.

Future sea level rises in the Arctic Ocean (Yin et al., 2010; Church et al., 2011) or in the Atlantic (Hu et al., 2008) could potentially alter the Bering Strait through-flow into the Arctic since this flow is driven primarily by the difference in sea level height between the North Pacific and the Arctic Ocean (Stigebrandt, 1984; Aagaard et al., 2006). Confidence in the accuracy of such projections remains low (Church et al., 2011), so the Bering Strait throughflow represents an unknown contributor to change, but still a potentially important tipping point for the future Arctic ecosystem. Further warming will also likely play some role in altering existing oceanic advection pathways and processes such as freshwater storage in the Beaufort Gyre.

In the Southern Ocean, there will also be increased warming of surface waters under climate change, with the greatest warming predicted to occur between $40^{\circ}$ and $60^{\circ} \mathrm{S}$, owing mostly to a southward translation of warmer subtropical waters (Sen Gupta et al., 2009). Recent CMIP5 projections (Meijers et al., 2012) show no consistent trend in the Antarctic Circumpolar Current among models. Despite changes in strength and location of westerly winds, Antarctic Circumpolar Current transport anomalies under future climate forcing scenarios (2070-2099 mean) varied between -26 and $+17 \mathrm{~Sv}$, and the Antarctic Circumpolar Current shifted polewards in models where the transport increases and equatorwards in models with transport decreases. Indeed, Meijers et al. (2012) found no significant correlation between the Antarctic Circumpolar Current position change and that of the westerly wind jet. While the Southern Ocean presently accounts for $75 \%$ of the global excess heat uptake and $43 \%$ of the anthropogenic carbon dioxide uptake (Frölicher et al., 2014), it is uncertain how climate change will impact the processes governing these uptake rates in the future (Sallee et al., 2013). In addition, surface waters are experiencing declines in $\mathrm{pH}$ and altered aragonite saturation states (ocean acidification), which are already impacting some marine organisms (Bednaršek et al., 2012). However, the degree to which ocean acidification will impact food webs and trophic interactions remains unclear. 


\subsection{Expected changes in sea-ice cover}

The advection of heat in the atmosphere coupled with changes in the wind impact sea ice. In the Arctic, the seasonal sea-ice cover will continue to shrink and thin during the 21st century. Based on the CMIP5 multi-model ensemble (IPCC, 2013), projections of average reductions in Arctic sea-ice extent for 2081-2100 compared to 1986-2005 range from 8\% to 34\% in February and from 43\% to $94 \%$ in September (medium confidence). The variability is based on different assumptions of the $\mathrm{CO}_{2}$ concentrations, with the lower and higher values for each month based on Representative Concentration Pathways (RCPs) of 2.6 and 8.5, respectively. A nearly ice-free Arctic Ocean (sea-ice extent $<1 \times 10^{6} \mathrm{~km}^{2}$ for at least 5 consecutive years) in September is likely before mid-century (Stroeve et al., 2012; IPCC, 2013; Overland et al., 2014). This projection is given medium confidence (IPCC, 2013), as controlling atmospheric and oceanic heat fluxes are not known with high precision, and small changes to the heat balance (on the order of $1 \mathrm{~W} \mathrm{~m}^{-2}$ ) have imparted large-scale alterations to the Arctic sea ice in the past (Kwok and Untersteiner, 2011). Because we currently lack the ability to detect and account for such subtle heat budget alterations, our ability to predict future changes of the Arctic sea-ice system is limited. That said, it is still expected that summer sea-ice cover will continue to decline in most of the Arctic Ocean and its marginal seas, although continued winter sea-ice presence is expected indefinitely (Overland and Wang, 2013; Stroeve et al., 2014; Wang and Overland, 2015).

The impact of advected heat varies for different regions in the Arctic, with higher ice losses expected in the European Arctic and Far Eastern Russian zones, and less north of the Canadian Archipelago (Barber et al., 2015). With continued warming conditions, seaice cover formation will continue to occur later and retreat earlier, leading to further reduction in sea-ice duration. In a seasonally icefree ocean, there will be no multi-year sea-ice habitat remaining. Because wind stress couples to the underlying ocean with different efficiencies for different ice types and concentrations (Shulze and Pickart, 2012), and thinner ice provides potential for greater deformation rates and ridge/keel formations, the character of the future first-year ice is difficult to predict.

Sea-ice cover is also expected to decrease in the Bering Sea and decrease further in the Barents seas. Variability in ice cover on the Bering Sea shelf is associated with wind-driven variability in the advection of warmer waters onto the shelf during winter (Stabeno et al., 2001), with enhanced onshelf flow when winds are predominantly from the southeast (Danielson et al., 2012a, 2012b). Model projections suggest more ice-free years in the southeast Bering Sea (Wang and Overland, 2015), while the winter cover of sea ice in the northern Bering Sea north of $60^{\circ} \mathrm{N}$ is not expected to decline significantly in the foreseeable future (Stabeno et al., 2012). In the Barents Sea, sea-ice variability is linked to the heat transport carried by the influx of Atlantic Water with increased heat transport leading to reduced sea ice (Anthun et al., 2012; Sandø et al., 2014). Previously much of the winter sea ice in the Barents Sea was transported from the Arctic by northerly winds (Sorteberg and Kvingedal, 2006) or was formed locally. Recently, however, the high heat flux into the Barents has acted to prevent local sea-ice formation, resulting in reduced ice coverage. This observed northward retreat of the position of the winter sea-ice maximum in the Barents Sea is expected to continue due to anticipated high heat transport by the Atlantic waters (Slagstad et al., 2011; Anthun et al., 2012; Smedsrud et al., 2013; Wassmann et al., 2015).

In the Antarctic, Hobbs et al. (2016) have reviewed recent changes in sea-ice cover and the drivers responsible for the changes. Climate models suggest a future decrease in sea-ice extent and volume (IPCC, 2013). The CMIP5 multi-model mean projects a decrease between 1986-2005 and 2081-2100 in seaice extent that ranges from $16 \%$ to $67 \%$ in February, for RCPs 2.6 and 8.5 , respectively, and from $8 \%$ to $30 \%$ in September. These projections, however, have low confidence because of the wide intermodel spread and the inability of almost all of the available models to reproduce the mean annual cycle, interannual variability, and the present overall increase of the Antarctic sea-ice areal coverage (IPCC, 2013; Hobbs et al., 2016).

\subsection{Expected changes in biota}

Climate change and its induced effects on advective processes in the ocean will impact the biota of polar marine ecosystems, both directly through impacts on physiology and prey resources, and indirectly through changes in habitat quality. For example, in the northeastern North Atlantic, the concentration of silicic acid in water flowing into the Arctic Ocean has declined by $25 \%$ over the last 20 years because of changes in the source regions of water masses entering the Norwegian Sea (Rey, 2012). This may lead to a decline in diatom production and a change in phytoplankton composition, with likely impacts on the food web of the southern Barents Sea (Rey, 2012).

\subsubsection{Effects of advective changes on primary production}

Projected future reductions in ice cover will increase the amount of irradiance penetrating the water column and the duration of the growing season, both of which will tend to increase primary production (Arrigo and van Dijken, 2011; Arrigo et al., 2012, 2014). Increased primary production requires input of additional nutrients into the photic zone through regeneration, vertical mixing, or advection. While the mechanisms are not clear, the increased frequency of surface fall blooms around the Arctic shelf and slope regions (Ardyna et al., 2014) suggests that additional nutrients are available for plankton to benefit from a longer growing season. In the Arctic, as ice retreats beyond the shelf break, it allows wind-induced upwelling to transport deep, warmer and nutrient-rich Pacific or Atlantic waters from the basins onto the shelves (Carmack and Chapman, 2003). This upwelling is projected to increase primary production on the shelves (Carmack and Chapman, 2003; Dmitrenko et al., 2006; Shulze and Pickart, 2012; Pickart et al., 2013; Tremblay et al., 2015). However, there is still no consensus as to whether the declining ice cover and thickness in the Arctic Basin will reduce or promote increased primary production, or whether ice algal primary production will remain a minor fraction ( $<20 \%$ ) of surface primary production in early spring on a pan-Arctic basis (Barber et al., 2015; Leu et al., 2015).

The main effect of changes in ice cover and timing of ice melt may be on the timing and fate of ice algae and phytoplankton blooms (Søreide et al., 2010; Leu et al., 2011). Early ice retreat and thinner ice will lead to an increase of irradiance in the water column and under the ice, which may shift the onset of ice algal and phytoplankton production to earlier in the season (Arrigo and van Dijken, 2011; Frey et al., 2011; Ji et al., 2013). Conversely, expanded areas of open water may delay the phytoplankton bloom due to wind-induced mixing delaying the formation of the seasonal pycnocline, as is apparently the case in the eastern Bering Sea (Baier and Napp, 2003; Bluhm and Gradinger, 2008; Hunt et al., 2011). Changes in timing of bloom events may have repercussions for herbivorous zooplankton and ice fauna species as the probability for a "mismatch" increases if the sequential timing is altered for primary production blooms relative to life history events of herbivores that rely on energetic input from the blooms (e.g., for reproduction and recruitment; Baier and Napp, 2003; Søreide et al., 2010; Varpe, 2012; Daase et al., 2013). In the southeastern Bering Sea, a mis-match between the timing of blooms 
related to sea-ice retreat and the needs of hebivores appears to have severe negative impacts on the recruitment and subsequent abundance of large copepods and euphausiids (Baier and Napp, 2003; Hunt et al., 2011; in press; Renner et al., 2016).

In the Southern Ocean, changes in advective processes will affect the type, timing, and amount of primary production. Eventually, the advection of heat from lower latitudes (Sen Gupta et al., 2009) will result in thinning of sea ice and earlier melt back, although such exchanges are at present limited. Atmospheric warming will result in ice melt, and thus an increase stratification, as well as provide increased irradiance to the water column. The increased duration of growth will result in increased annual production. The thinning of sea ice could allow more under-ice production, although such production in the Southern Ocean is extremely small (Arrigo et al., 2012, 2014). Available iron in the upper water column during summer is at vanishingly low concentrations at present. Glacial melt can provide a substantial source of iron, and because advective processes provide the heat to drive such basal ablation, changes in advection can locally impact iron sources and hence productivity (Arrigo et al., 2015). Thus, the increased duration of the growing season will result in a modestly increased annual production, and the increase will be at daily rates similar to those found today.

It is also uncertain how wind forcing will change, although it is thought that, as the ozone hole recovers, there may be a reduction in the westerly winds (Thompson and Solomon, 2002; Meijers et al., 2012). This would result in diminished wind mixing and increased stratification. Increased stratification will reduce fluxes of nutrients into the euphotic zone in all seasons except winter, but will provide an optimal irradiance environment for phytoplankon (Sarmiento et al., 1998). Additionally, increased stratification generally supports diatom growth relative to other functional groups (e.g., haptophytes) in nutrient-replete conditions (Kropuenske et al., 2009). Certain localized regions of enhanced production exist today where bathymetrically driven upwelling and deep vertical supply iron to surface waters (Prézelin et al., 2000; Quéguinér, 2013), and it is expected that these will continue with little change in the future.

\subsubsection{Effects of advective changes on sea-ice invertebrate fauna}

Sea ice is a critical habitat for the organisms that live within the ice and on its surfaces. In the Arctic, further disappearance of multi-year ice will likely decrease the abundance of long-lived (6 years), ice-dependent amphipod species, such as G. wilkitzkii (Beuchel and Lønne, 2002; Gradinger et al., 2010; Barber et al., 2015), with possible replacement by the more pelagic amphipod Eusirus holimi (H. Hop, diving obs.). Species diversity has already declined, at least regionally (Melnikov et al., 2002), but differences in sampling efforts also need to be taken into consideration when determining change. Allochthonous macrofaunal species, as well as ice algae and meiofauna, are expected to be less affected since they rely on sea ice for only part of their life cycles and can re-colonize seasonal ice (Søreide et al., 2010; Hop et al., 2011). Changes in the location of sea ice will impact the fate of ice-dwelling organisms when the ice melts and will also affect the vertical flux of particulate organic matter to the benthos.

The future role of sea ice in the reproduction and recruitment of krill and silverfish in the Southern Ocean is uncertain. Since Pleuragramma eggs have been observed floating in platelet ice under sea ice, sea ice may be important as a nursery ground for this fish (Vacchi et al., 2012). Reductions in seasonal sea-ice extent may lower krill recruitment and larval survival in the Bellingshausen and Scotia seas (Kawaguchi and Satake, 1994; Loeb et al., 1997; Siegel, 2000; Atkinson et al., 2004). However, krill have many alternative behaviors that vary between location and seasons, and these may reduce their vulnerability to declines in sea-ice cover (Daly, 2004).

\subsubsection{Effects of advective changes on benthos}

Changes in currents over shelves have the potential to affect the species composition, distribution and abundance of the benthos through changing sediment grain size (Lovvorn et al., 2014), reshaping bottom features, and modifying the overlaying hydrography (Blacker, 1957; Cushing, 1982). Reproductive forms of many boreal species are transported to the Arctic in Atlantic Water. When these currents warm or become stronger, new species may find their way north. Such was likely the case for the reappearance of the blue mussel on Spitsbergen after an apparent absence of over 1000 years (Berge et al., 2005, 2006). Thus, under future climate change, increased spreading of boreal species to the north is expected. Furthermore, reductions in sea ice in the central Arctic will likely enhance invasion of benthic taxa from the Pacific to the Atlantic due to more freely flowing currents (see discussion in Renaud et al., 2015).

It is not known how expected changes in the Antarctic will influence the benthos, although most of the mechanisms that apply to the Arctic might be expected to apply in the Antarctic as well.

\subsubsection{Effects of advective changes on zooplankton}

In both the Arctic and the Antarctic, a faster melt-back of seasonal sea-ice cover (e.g., Danielson et al., in press) will affect the match between the needs of zooplankton that graze on under-ice algae and its availability. For example, in the Arctic, early retreat of sea ice may affect the productivity of Calanus glacialis, since their reproduction and/or the growth of the new generation depends on energy provided by ice algae, (e.g., ice-associated diatoms, such as Nitzschia frigida), as well as on the timing of ice algae and pelagic blooms relative to each other (Runge and Ingram, 1991; Søreide et al., 2010). Likewise, in the Southern Ocean, loss of sea ice would affect the productivity of both Antarctic krill and copepods (Atkinson et al., 2004).

Zooplankton are generally expected to shift their distributions poleward as temperatures increase. However, as most polar zooplankton are only capable of living within a restricted temperature range, this will in part limit the extent of their possible distributional shifts under climate change. Existing, steep temperature gradients, e.g., across the Antarctic Polar Front, will continue to limit how far poleward sub-Antarctic taxa will be able to penetrate in the future (Mackey et al., 2012). In the Arctic, the high seasonality in incoming solar radiation and the resulting seasonality in food availability will determine how far poleward some zooplankton will be able to move (Ji et al., 2012; Sundby et al., 2016). Changes in current flow or temperature increases are also expected to alter the timing of life cycle development and food resources needed for reproduction.

In the Chukchi Sea and Chirikov Basin, the biomass of zooplankton is largely determined by northward flows through Bering Strait. Thus, any change in advection through the Strait would be expected to affect proportionately the biomass of zooplankton present in the Chirikov Basin and the Chukchi Sea. Flow through Bering Strait has increased since 2001 (Woodgate et al., 2012, 2015), but it is unclear if and how its magnitude may change under climate warming. Similarly, changes in the advection from the Norwegian Sea into and through the Barents Sea and through Fram Strait affect the transport of zooplankton into the Arctic Basin. Recent modeling studies suggest a $15-30 \%$ increase in the transport of expatriate oceanic copepods into the Arctic Basin (Wassmann et al., 2015).

In the Antarctic, there may be increases in advection of zooplankton from the western Antarctic Peninsula to South Georgia, 
as well as shorter transport times (Renner et al., 2012). The shorter transport times may lead to lower krill mortality, but the krill also may be smaller upon arrival, which could affect mortality due to predation. Alternatively, future warming and the reduction of sea ice over the next century may lead to rapid reductions in krill abundance and biomass as a result of reduced influx of krill into the northern regions of the Scotia Sea, though this prediction is highly uncertain (Murphy et al., 2007b). West Antarctic Peninsula shelf regions also may experience significant reductions of sea ice, which, in turn, may reduce food availability to larval krill during winter and spring.

\subsubsection{Effects of advective changes on fish}

Advection affects fish both through the dispersal of eggs and larvae and through the advection of their prey (zooplankton). Advection from the sub-Arctic into the Arctic in both the Pacific and Atlantic sectors provides potential pathways of dispersal for planktonic eggs and larvae and facilitates the expansion of fish populations into a warming Arctic (Hollowed et al., 2013). The advection of warmer waters into the Arctic, combined with local warming, suggests that boreal fish species may increasingly outcompete cold-adapted, stenothermic (requiring a narrow range of ambient temperatures) species (Peck et al., 2004; Laurel et al., 2016a, 2016b), resulting in a "borealization" of the Arctic (Fossheim et al., 2015). Significant changes in the advection of zooplankton or ichthyoplankton under climate warming would cause changes in the populations of fish. For example, zooplankton advected from the Norwegian Sea in Atlantic Water support fish populations in the southern Barents Sea. Seasonal and interannual changes in the flow of Atlantic Water into the Barents Sea have significant impacts on the availability of zooplankton to these predators (Dalpadado et al., 2012a, 2012b).

The potential changes in direction and speeds of Southern Ocean currents in the future are highly uncertain. If changes do occur, they could disrupt the interactions of ocean currents with the life cycles of species such as toothfish, as the currents are important in maintaining toothfish through determining the degree of connectivity between populations (Ashford et al., 2010; Damerau et al., 2012).

10.4.6. Effects of advective changes on seabirds and marine mammals Neither polar seabirds nor marine mammals use currents for their dispersal or travel, although in both polar oceans these predators depend on the advection of zooplankton. Likewise, the advection of detritus and particulate carbon supports rich benthic communities on shallow Arctic shelves that in turn support benthic-foraging marine mammals. Future increases in precipitation, river runoff, and coastal erosion rates are expected to increase the amount of detritus delivered to the Arctic Ocean and hence are likely to alter the structure and functioning of benthic communities (Carmack et al., 2015).

Likely, the most important impact of advection on seabirds and marine mammals will be to alter the spatial and temporal distributions of sea ice. In the Arctic, only a few species of seabirds are dependent on sea ice as a platform on which to forage or rest (e.g., Divoky et al., 2015); in contrast, in the Antarctic many species of seabirds use sea ice during their life cycles. However, the response of ice-associated seabirds is likely to differ regionally based on projected increases or decreases in sea-ice cover (Croxall et al., 2002; D.G. Ainley et al., 2010; D.A. Ainley et al., 2010; Younger et al., 2016). Declines in sea-ice cover may or may not have adverse impacts on seabirds in all regions of the Antarctic. For example, in years of extreme sea-ice cover in East Antarctica, seabird reproduction largely failed (Emmerson and Southwell, 2008; Barbraud et al., 2015). Many species of marine mammals in both the Arctic and the Antarctic require sea ice as a platform on which to rest, forage, give birth to and nurse their pups, as well as to escape from predators (e.g., Laidre et al., 2015). As the area of ice available to them declines, they will be forced to use alternative habitats or decline. In contrast, other species of marine mammals may be able to move into higher latitude regions as ice melts and the conditions change (e.g., Moore and Huntington, 2008; Siniff et al., 2008; Costa et al., 2010).

The availability of sea ice over shallow shelves is important for some Arctic pinnipeds. If the only ice available to resting walrus pups is over the Arctic Basin, then the walrus may turn to land haul-outs and utilize different and more coastal foraging regions, with unknown consequences for the population (Jay et al., 2012). Those seal species that utilize ice for pupping will likely suffer larger pup mortality and ultimately reduced abundance. Polar bears use ice for migration, mating, and to prey on seals. With reductions in sea ice, the sea-ice habitat will shrink substantially and the numbers of both polar bears and ice-dependent seals are expected to decline (Loeng et al., 2005; Durner et al., 2009; Rode et al., 2014; Laidre et al., 2015). Polar bears may have to retreat to land, which will likely lead to increased starvation for lack of appropriate food and declines in abundance (Hamilton et al., 2014).

In the Antarctic, substantial spatial and temporal variability in transport occurs in the marginal seas, as well as at much larger, continent-wide spatial scales (Piñones et al., 2013b). An important transport of zooplankton to seabirds and marine mammals occurs in that portion of the Antarctic Circumpolar Current that carries krill from the Antarctic Peninsula and the Weddell Sea to South Georgia (Murphy et al., 1998, 2007a; Trathan et al., 2006, 2007). Should this transport of krill diminish or fail, the immense populations of seabirds and marine mammals at South Georgia would likely not persist. If advected heat reduces sea-ice extent, and concomitantly krill production, then organisms dependent on krill, including those at South Georgia, will have a reduced prey base. This is also true of other species, such as several species of penguins, many species of volant seabirds, seals, including Antarctic fur seals, crabeater seals (Lobodon carcinophagus), and the leopard seal (Hydrurga leptonyx) (Costa and Crocker, 1996), as well as baleen whales. For example, Wiedenmann et al. (2011) predict that a loss of krill production due to sea-ice loss would severely restrict blue whale (Balaenoptera musculus) recovery.

\subsubsection{Impacts of advective changes at the ecosystem level}

Because of the differences in advective regimes, as discussed above, the marine ecosystems of the Arctic and Southern oceans have had very different periods of isolation and thus evolutionary histories. De Santana et al. (2013) analyzed and compared the topologies, in terms of trophic connections, of the food web of an Arctic marine ecosystem, the Barents Sea food web, with two food webs described for the Southern Ocean. They found that the Barents Sea has a greater diversity of predators and "top species" and the Southern Ocean systems examined have a greater diversity of prey and basal species (de Santana et al., 2013). They argued that the Barents Sea may be more vulnerable to trophic cascades that could result from the loss of key predators, and that the Antarctic systems may be more robust to random extinctions, with the exception that the loss of the most connected species, such as Antarctic krill, could have profound effects. Although the Barents Sea, and in particular the southern Barents Sea, may not be typical of most Arctic marine ecosystems, it is certainly well connected to the North Atlantic, both in terms of the advection of nutrients, phytoplankton and zooplankton, but also in terms of its openness to invasion by fish species from lower latitudes (e.g., Hunt et al., 2013). The de Santana et al. (2013) comparison of these food webs is perhaps most important as it brings into focus the potential vulnerability, not just of species, but of these entire ecosystems to perturbations that may result from climate change. Advection, and the 
resulting connections to lower latitude seas, may be an important element in determining the resilience of marine ecosystems to climate warming.

\section{Conclusions}

The differences between the Arctic Seas and the Southern Ocean are profound. The Arctic is an ocean surrounded by land, while the Antarctic is a land mass surrounded by ocean, which influences both the atmospheric and oceanic circulation patterns, as well as the living marine resources in both of these polar seas.

\section{General circulation patterns}

The Arctic Ocean has limited but strong connections to lowerlatitude oceans, whereas in the Southern Ocean, despite its apparent broad connections to the Atlantic, Indian, and Pacific oceans, surface and intermediate depth waters are far less connected to the sub-Antarctic. In the sub-polar Northern Hemisphere, ocean currents have a strong meridional component, with northward flows through the Bering Strait, southward flows through the Canadian Archipelago, and two-way exchanges through Fram Strait and the Barents Sea. The northward flowing currents carry heat, nutrients, and both phyto- and zooplankton into the Arctic.

In the Southern Ocean, strong westerly winds drive the wide and deep Antarctic Circumpolar Current, which disperses organisms principally longitudinally. Meridional flow is limited and, together with the strong circumpolar fronts, tends to isolate Antarctic waters from the sub-Antarctic. The exceptions to this simple annular circulation pattern of surface and near-surface currents are the large Ross and Weddell gyres, which penetrate farther south than the annular flows, and the northeastward flows that follow the Scotia Arc to South Georgia.

\section{Freshwater input}

In the Arctic, freshwater input comes directly from several large rivers and indirectly via the low-salinity Alaskan and Norwegian Coastal currents. The Antarctic lacks major inputs of freshwater from rivers and advection from lower latitudes. Instead, freshwater input is mainly from sub-glacial flows, which are increasing (Meredith et al., 2013), and, in limited areas, from the melting of icebergs.

\section{Heat and ice}

In the Northern Hemisphere, arguably the most important impact of northward flows in both the atmosphere and the ocean is the transport of heat into the Arctic Ocean. This advected heat, together with solar radiation and other surface heat fluxes is responsible for the seasonal melting of sea ice and impacts the timing of events such as ice edge blooms. In contrast, as a result of the strong annular organization of the Southern Ocean currents and water masses, less heat is transported poleward than in the Arctic. With the exception of the northern Antarctic Peninsula, sea-ice cover in the Southern Ocean has statistically increased (Simmonds, 2015).

\section{Evolution}

In the Northern Hemisphere, the strong connections between the Arctic and sub-Arctic Seas have resulted in the sharing of species, not only between the sub-Arctic and the Arctic, but also at times between the Pacific and Atlantic Oceans via transport across the Arctic Ocean. The Arctic has been open for several thousands of years and is still in a state of continuing colonization, with more exchanges expected (Dayton et al., 1994). In contrast, in the Southern Hemisphere, the annular flows tend to isolate the surface waters south of the Antarctic Circumpolar Current from the rest of the World Ocean. This current has existed for millions of years, thereby allowing the Southern Ocean to develop a unique flora and fauna (Gili et al., 2006; Rogers et al., 2012). This isolation has resulted in the evolution of zooplankton and families of fish adapted to living at extremely low, but constant temperatures. These stenothermic species may not be able to adapt to quickly rising temperatures.

\section{Nutrient delivery and primary production}

In the Arctic, a major portion of available nutrients is replenished by horizontal transport northward in surface or nearsurface waters from both the Pacific and the Atlantic. These waters provide the macro-nutrients required to fuel primary production in the Arctic, the majority of which occurs on the shelves. In contrast, in the Antarctic, vertical advection of nutrients through upwelling in the Southern Ocean is the principal mechanism for replenishment of nutrients in surface waters. This upwelling brings Circumpolar Deep Water towards the surface, where mixing brings this water, as well as iron from the sediments, into the euphotic zone.

As sea ice retreats over the Arctic basin earlier in the year, winddriven upwelling at the shelf edge may increase the availability of nutrients. In the Antarctic, this is a less important mechanism as the shelves are deep. Iron is not a limiting micro-nutrient in the Arctic, which is in contrast to the Southern Ocean. The latter is a macro-nutrient-replete system and low iron concentrations limit primary production throughout most of the region.

Changes in light availability and nutrient delivery to the euphotic zone will affect the amounts of primary production in both the Arctic and the Southern oceans, and likely as well, the species composition of the primary producers. Perhaps as important, changes in the timing of primary production may affect its availability to herbivorous zooplankton, and mis-matches in the timing of the needs for plant cells versus their availability may cause a shift in the fate of the primary production.

\section{Benthos}

Advection is important in both hemispheres as a means of supplying organic material to the benthos from distant locations of surface primary production. There is tight pelagic-benthic coupling in some of the shallow Arctic shelves such as the Chukchi and Barents seas, but in the deeper shelf areas of both the Arctic and the Antarctic, pelagic-benthic coupling is less likely. These conditions have shaped different benthic shelf assemblages in the Polar Regions.

\section{Zooplankton}

In the Northern Hemisphere, the meridional flows are important for transporting zooplankton both from the sub-Arctic seas to the Arctic, and from the Arctic to the sub-Arctic. In the Pacific sector, northward transport of zooplankton is essential for the support of high numbers of seabirds and marine mammals in the Chukchi Sea. In the northeastern Atlantic, the high secondary and tertiary productivity of the southern Barents Sea is strongly supported by the advection of zooplankton from the Norwegian Sea. Likewise, southward flows through the west side of Fram Strait carry ice-associated organisms and Arctic zooplankton along the east side of Greenland. Most of the ice-associated biomass likely sinks to the bottom as the ice melts, whereas zooplankton are carried far south along the Greenland coast. In the Southern Ocean, the annual flows homogenize the populations of zooplankton around the continent. Only in places like the Scotia Sea or the Ross Sea are there significant northward transports of zooplankton, which are vital to the well-being of colonies of seabirds and marine mammals that depend upon the advected resources.

\section{Fish}

Fish that have pelagic eggs or juveniles depend on advection to transport offspring from spawning areas to suitable nursery areas. In the Arctic, advection of pelagic stages coupled with warming waters may permit poleward advances by some species (Hollowed et al., 2013). For others, especially cold-adapted stenotherms, increased physiological challenges may result in range contractions because warming waters affect the ability of poikilothermic organisms to cope with other stresses (Pörtner, 2010, 2012). We know little about how these physiological responses 
will affect species interactions and, in turn, ecological function (e.g., Pörtner and Farrell, 2008; Pörtner and Peck, 2010). Changes in advection are likely to affect the rates and patterns of the poleward advance or retreat of fish populations, but are unlikely to halt the borealization of the Arctic. In the Southern Ocean, changes in zonal advection may affect the connectivity among populations, but advection is likely to play a more limited role in latitudinal shifts in distribution compared to the Arctic. However, enhanced upwelling of deep waters may facilitate the poleward movement of deep-water species onto the shelf.

\section{Seabirds and marine mammals}

Regionally in both the Arctic and the Antarctic, seabirds and marine mammals depend on currents to advect zooplankton and small forage fishes to the vicinity of breeding locations. Within regions, these predators often depend on fronts and other physical mechanisms to concentrate prey or enhance the accessibility of prey. Changes in the location of fronts and their associated transport may alter the predictable supply of zooplankton prey to island and open ocean predators.

\section{Future}

The two Polar Regions, will likely respond to global warming by following different trajectories. Currently, the Arctic is warming while much of Antarctica is cooling. Eventually both regions are expected to warm. As they do, sea ice will be present for shorter periods, will melt more rapidly, and will cover decreasing areas. This decline will have a particularly severe impact on ice-dependent organisms, such as some species of zooplankton and fish that use the sea-ice under-surface habitat, or the seabirds and marine mammals that require sea ice as a platform for foraging, mating, giving birth or resting. Once multi-year ice is gone, the organisms dependent on a stable sea-ice habitat will decrease or disappear. Likewise, stenothermic cold-water species will be disadvantaged, particularly in the Arctic, which will warm faster. Heat directly affects physiological rates and the ecological roles of key species may be compromised by their physiological responses to warming. New species will come to occupy the Polar Regions, due to both range expansions and introductions, and they may outcompete or prey on the resident polar species. New polar marine ecosystems will replace those that are present now. It is certain that the future advective regimes in the Arctic and Antarctic will play an important role in the composition and productivity of the future polar marine ecosystems.

\section{Geographic locators}

Arctic, sub-Arctic, North Pacific Ocean, Bering Sea, Chukchi Sea, Beaufort Sea, Arctic Ocean, North Atlantic Ocean, Barents Sea, Baffin Bay, Southern Ocean, sub-Antarctic, Antarctic, Ross Sea, Weddell Sea, West Antarctic Peninsula region, South Georgia.

\section{Acknowledgments}

The seeds for this paper were sown in May 2012, when the IMBER regional programs, ESSAS (Ecosystem Studies of SubArctic and Arctic Seas) and ICED (Integrating Climate Ecosystem Dynamics), which focuses on the Antarctic, held a workshop on "Polar Comparisons: the effects of climate change on advective fluxes in high latitude regions" in Yeosu, Korea. The authors thank both PICES and ICES for support of the workshop. GLH's travel was supported by ESSAS, and EJM's, DWG's and WOS's by ICED.

\section{References}

Aagaard, K., Carmack, E.C., 1989. The role of sea ice and other fresh water in the Arctic circulation. J. Geophys. Res.: Oceans 94 (C10), 14485-14498.

Aagaard, K., Coachman, L.K., Carmack, E., 1981. On the halocline of the Arctic Ocean. Deep-Sea Res. Part I 28, 529-545.
Aagaard, K., Weingartner, T., Danielson, S.L., et al., 2006. Some controls on flow and salinity in Bering Strait. Geophys. Lett. 33, L19602. http://dx.doi.org/10.1029/ 2006GL026612.

ACIA, 2005. Arctic Climate Impact Assessment. Cambridge University Press, New York, NY. 1042 pp.

Ackley, S.F., Sullivan, C.W., 1994. Physical controls on the development and characteristics of Antarctic sea-ice biological communities - a review and synthesis. Deep-Sea Res. Part I 41, 1583-1604.

Aguilar-Islas, A.M., Rember, R.D., Mordy, C.W., Wu, J., 2008. Sea ice-derived dissolved iron and its potential influence on the spring algal bloom in the Bering Sea. Geophys. Res. Lett. 35, L24601. http://dx.doi.org/10.1029/ 2008 GL035736.

Ainley, D.G., 2002. The Adélie Penguin: Bellwether of Climate Change. Columbia U. Press. 416 pp.

Ainley, D., 2007. Insights from study of the last intact neritic marine ecosystem. Trends Ecol. Evol. 22 (9), 444-445. http://dx.doi.org/10.1016/j.tree.2007.06.007.

Ainley, D.G., Ballard, G., 2012. Trophic interactions and population trends of killer whales (Orcinus orca) in the southern Ross Sea. Aquat. Mammals 38, 153-160.

Ainley, D.G., Jacobs, S.S., 1981. Sea-bird affinities for ocean and ice boundaries in the Antarctic. Deep-Sea Res. Part I 28, 1173-1185.

Ainley, D.G., Ballad, G., Dugger, K.M., 2006. Competition among penguins and cetaceans reveals trophic cascades in the western Ross Sea, Antarctica. Ecology 87, 2080-2093.

Ainley, D.G., Ballard, G., Jones, R.M., et al., 2015. Trophic cascades in the western Ross Sea, Antarctica: revisited. Mar. Ecol. Prog. Ser. 534, 1-16. http://dx.doi.org 10.3354/meps11394.

Ainley, D.G., Ballard, G., Weller, J., 2010. Ross Sea Biodiversity Part I: Validation of the 2007 CCAMLR Bioregionalization Workshop Results towards Including the Ross Sea in a Representative Network of Marine Protected Areas in the Southern Ocean. WG-EMM-10/11 CCAMLR, Hobart.

Ainley, D.G., Dugger, K.M., Toniolo, V., et al., 2007. Cetacean occurrence patterns in the Amundsen and southern Bellingshausen Sea sector, Southern Ocean. Mar Mammal Sci. 23, 287-305.

Ainley, D.G., Jacobs, S.S., Ribic, C.A., et al., 1998. Seabird distribution and oceanic features of the Amundsen and southern Bellingshausen seas. Antarct. Sci. 10, $111-123$.

Ainley, D.G., Ribic, C.A., Fraser, W.R., 1992. Does prey preference affect habitat choice in Antarctic seabirds. Mar. Ecol. Prog. Ser. 90, 207-221. http://dx.doi.org/ 10.3354/meps090207.

Ainley, D.A., Russell, J., Jenouvier, S., et al., 2010. Antarctic penguin response to habitat change as Earth's troposphere reaches 2 degrees $C$ above preindustrial levels. Ecol. Monogr. 80, 49-66.

Ajiad, A.M., Oganin, I.A., Gjøsæter, H., 2011. Polar cod. In: Jakobsen, T., Ozhigin, V.K. (Eds.), The Barents Sea. Ecosystem, Resources, Management. Half a Century of Russian-Norwegian Cooperation. Tapir Academic Press, Trondheim, pp. 315328.

Alexeev, V.A., Langen, P.L., Bates, J.R., 2005. Polar amplification of surface warming on an aquaplanet in "ghost forcing" experiments without sea ice feedbacks. Clim. Dyn. 24, 655-666.

Allan, E.L., Froneman, P.W., Durgado, J.V., et al., 2013. Critical indirect effects of climate change on sub-Antarctic ecosystem functioning. Ecol. Evol. 3, 29943004. http://dx.doi.org/10.1002/ece3.678.

Alsvåg, J., Agnalt, A.-L., Jørstad, K.E., 2009. Evidence for a permanent establishment of the snow crab (Chionoecetes opilio) in the Barents Sea. Biol. Invasions 11, 587595.

Ambrose Jr., W.G., Renaud, P.E., 1995. Benthic response to water column productivity patterns: evidence for benthic-pelagic coupling in the Northeast Water Polynya. J. Geophys. Res.: Oceans 100, 4411-4421.

Andriashev, A.P., Mukhomediyarov, B.F., Pavshtiks, E.A., 1980. O massovykh skopleniyakh kriopelagicheskikh treskovykh ryb Boreogadus saida i Arctogadus glacialis okolopalyusnykh rajonakh arktiki (On mass congregations of the cryopelagic cod fishes (Boreogadus saida and Arctogadus glacialis) in circumpolar regions of the Arctic). In: Vinogradov, M.E., Melnikov, I.A. (Eds.), Biologiya Tsentral'nogo arkticheskogo bassejna (Biology of the Central Arctic Basin). Shirshov Inst. Oceanology, Academy of Sciences, U.S.S.R., pp. 196-211 (Transl. by Northwest and Alaska Fisheries Center, Seattle, 1981, 14 pp.).

Ansorge, I.J., Froneman, P.W., Pakhomov, E.A., et al., 1999. Physical-biological coupling in the waters surrounding the Prince Edward Islands (Southern Ocean). Polar Biol. 21, 135-145. http://dx.doi.org/10.1007/s003000050344.

Anthun, M., Eldevik, T., Smedsrud, L.H., Skagseth, O., Ingvaldsen, R.B., 2012. Quantifying the influence of Atlantic heat on Barents Sea ice variability and retreat. J. Clim. 25, 4736-4743.

Arblaster, J.M., Meehl, G.A., Karoly, D.J., 2011. Future climate change in the Southern Hemisphere: competing effects of ozone and greenhouse gases. Geophys. Res. Lett. 38, L02701. http://dx.doi.org/10.1029/2010GL045384.

Ardyna, M., Babin, M., Gosselin, M., et al., 2014. Recent Arctic Ocean sea ice loss triggers novel fall phytoplankton blooms. Geophys. Res. Lett. 41, 6207-6212.

Arndt, C., Lønne, O.J., 2002. Transport of bioenergy by large scale Arctic ice drift. In: Proceedings of the 16th IAHR International Symposium on Ice. International Association of Hydraulic Engineering and Research, Dunedin, New Zealand, pp. $103-111$.

Arndt, C.E., Pavlova, O., 2005. Origin and fate of ice fauna in the Fram Strait and Svalbard area. Mar. Ecol. Prog. Ser. 301, 55-66.

Arndt, C.E., Swadling, K.M., 2006. Crustacea in Arctic and Antarctic sea ice: distribution, diet and life history strategies. Adv. Mar. Biol. 51, 197-315. 
Arndt, C., Fernandez-Leborans, G., Seuthe, L., et al., 2005. Ciliated epibionts on the Arctic sympagic amphipod Gammarus wilkitzkii as indicators for sympagobenthic coupling. Mar. Biol. 147, 643-652.

Arntz, W.E., Brey, T., Gallardo, V., 1994. Antarctic zoobenthos. Oceanogr. Mar. Biol. Annu. Rev. 32, 241-304.

Arrigo, K.R., van Dijken, G.L., 2003. Phytoplankton dynamics within 37 Antarctic coastal polynyas. J. Geophys. Res. 108 (C8), 3271. http://dx.doi.org/10.1029/ 2002JC001739.

Arrigo, K.R., van Dijken, G.L., 2011. Secular trends in Arctic Ocean net primary production. J. Geophys. Res. 116, C09011. http://dx.doi.org/10.1029/ 2011JC007151.

Arrigo, K.R., van Dijken, G.L., 2015. Continued increases in Arctic Ocean primary production. Prog. Oceanogr. 136, 60-70. http://dx.doi.org/10.1016/j. pocean.2015.05.002.

Arrigo, K.R., Lizotte, M.P., Mock, T., 2010. Primary producers and sea ice. In: Thomas, D.N., Dieckmann, G.S. (Eds.), Sea Ice. second ed. Blackwell Science Ltd., Oxford, UK, pp. 283-326.

Arrigo, K.R., Perovich, D.K., Pickart, R.S., et al., 2012. Massive phytoplankton blooms under Arctic sea ice. Science 336, 1408. http://dx.doi.org/ 10.1126/science.1215065.

Arrigo, K.R., Perovich, D.K., Pickart, R.S., et al., 2014. Phytoplankton blooms beneath the sea ice in the Chukchi Sea. Deep-Sea Res. Part II 105, 1-16. http://dx.doi.org/ 10.1016/j.dsr2.2014.03.018.

Arrigo, K.R., Robinson, D.H., Dunbar, R.B., et al., 2003. Physical control of chlorophyll a, POC, and PON distributions in the pack ice of the Ross Sea, Antarctica. J. Geophys. Res. 108 (C10), 3316. http://dx.doi.org/10.1029/2001JC001138.

Arrigo, K.R., Robinson, D.H., Worthen, D.L., et al., 1999. Phytoplankton community structure and the drawdown of nutrients and $\mathrm{CO}_{2}$ in the Southern Ocean. Science 283, 365-367.

Arrigo, K.R., van Dijken, G.L., Ainley, D.G., Fahnestock, M.A., Markus, T., 2002. Ecological impact of a large Antarctic iceberg. Geophys. Res. Lett. 29 (7), 1104. http://dx.doi.org/10.1029/2001GL014160.

Arrigo, K.R., van Dijken, G.L., Bushinsky, S., 2008. Primary production in the Southern Ocean, 1997-2006. J. Geophys. Res. 113, C08004. http://dx.doi.org 10.1029/2007JC004551.

Arrigo, K.R., van Dijken, G.L., Strong, A.L., 2015. Environmental controls of marine productivity hot spots around Antarctica. J. Geophys. Res. 120, 5545-5565. http://dx.doi.org/10.1002/2015JC010888.

Ashford, J.R., Jones, C., 2007. Oxygen and carbon stable isotopes in otoliths record spatial isolation of Patagonian toothfish (Dissostichus eleginoides). Geochim. Cosmochim. Acta 71, 87-94. http://dx.doi.org/10.1016/j.gca.2006.08.030.

Ashford, J.R., Dinniman, M., Brooks, C., et al., 2012a. Does large-scale ocean circulation structure life history connectivity in Antarctic toothfish (Dissostichus mawsoni)? Can. J. Fish. Aquat. Sci. 69, 1903-1919. http://dx.doi.org/10.1139/ f2012-111.

Ashford, J.R., Fach, B.A., Arkhipkin, A.I., Jones, C.M., 2012b. Testing early life connectivity supplying a marine fishery around the Falkland Islands. Fish. Res. 121, 144-152. http://dx.doi.org/10.1016/j.fishres.2012.01.023.

Ashford, J.R., La Mesa, M., Fach, B.A., Jones, C., Everson, I., 2010. Testing early life connectivity using otolith chemistry and particle-tracking simulations. Can. J. Fish. Aquat. Sci. 67 (8), 1303-1315. http://dx.doi.org/10.1139/f10-065.

Ashjian, C.J., Braund, S.R., Campbell, R.G., et al., 2010. Climate variability, oceanography, bowhead whale distribution and Iñupiat subsistence whaling near Barrow, Alaska. Arctic 63, 179-194.

Assmann, K.M., Jenkins, A., Shoosmith, D.R., et al., 2013. Variability of Circumpolar Deep Water transport onto the Amundsen Sea continental shelf through a shelf break trough. J. Geophys. Res.: Oceans 118, 6603-6620.

Atkinson, A., Siegel, V., Pakhomov, E., Rothery, P., 2004. Long-term decline in krill stock and increase in salps within the Southern Ocean. Nature 432, 100-103. http://dx.doi.org/10.1038/nature02950.

Atkinson, A., Siegel, V., Pakhomov, E.A., et al., 2008. Oceanic circumpolar habitats of Antarctic krill. Mar. Ecol. Prog. Ser. 362, 1-23.

Babb, D.G., Galley, R.J., Asplin, M.G., et al., 2013. Multiyear sea ice export through the Bering Strait during winter 2011-2012. J. Geophys. Res. 118, 5489-5503.

Baier, C.T., Napp, J.M., 2003. Climate-induced variability in Calanus marshallae populations. J. Plankton Res. 25, 771-782.

Bano, N., Ruffin, S., Ransom, B., Hollibaugh, J.T., 2004. Phylogenetic composition of Arctic Ocean archaeal assemblages and comparison with Antarctic assemblages. Appl. Environ. Microbiol. 70, 781-789.

Barange, M., O’Boyle, R., Cochrane, K.L., et al., 2010. Marine resources management in the face of change: from ecosystem science to ecosystem-based management. In: Barange, M., Field, J.G., Harris, R.P., Hofmann, E.E., Perry, R.I., Werner, F.E. (Eds.), Marine Ecosystems and Global Change. Oxford University Press (Chapter 9).

Barber, D.G., Hop, H., Mundy, C.J., et al., 2015. Selected physical, biological and biogeochemical implications of a rapidly changing Arctic Marginal Ice Zone. Prog. Oceanogr. 139, 122-150.

Barbraud, C. Weimerskirch, H., 2001. Contrasting effects of the extent of sea-ice on the breeding performance of an Antarctic top predator, the Snow Petrel Pagodroma nivea. J. Avian Biol. 32, 297-302.

Barbraud, C., Delord, K. Weimerskirch, Henri., 2015. Extreme ecological response of a seabird community to unprecedented sea ice cover. R. Soc. Open Sci. 2 (5), 140456.

Barnes, D.K.A., Clarke, A., 1995. Seasonality of feeding activity in Antarctic suspension feeders. Polar Biol. 15, 335-340.
Barrett, R.T., Anker-Nilssen, T., Gabrielsen, G.W., Chapdelaine, G., 2002. Food consumption by seabirds in Norwegian waters. ICES J. Mar. Sci. 59 (43), 57.

Barry, J.P., Grebmeier, J.M., Smith, J., Dunbar, R.B., 2003. Oceanographic versus seafloor-habitat control of benthic megafaunal communities in the SW Ross Sea, Antarctica. In: Ditullio, G.R., Dunbar, R.B. (Eds.), Biogeochemistry of the Ross Sea. American Geophysical Union, Washington, DC. http://dx.doi.org/10.1029/ 078ARS21.

Bathmann, U., Fischer, G., Miller, P.J., Gerdes, D., 1991. Short-term variations in particulate matter sedimentation off Kapp Norvegia, Weddell Sea, Antarctica: relation to water mass advection, ice cover, plankton biomass and feeding activity. Polar Biol. 11, 185-195.

Bednaršek, N., Tarling, G.A., Bakker, E., et al., 2012. Extensive dissolution of live pteropods in the Southern Ocean. Nat. Geosci. 5, 881-885.

Belchier, M., Collins, M.A., 2008. Recruitment and body size in relation to temperature in juvenile Patagonian toothfish (Dissostichus eleginoides) at South Georgia. Mar. Biol. 155, 493-503. http://dx.doi.org/10.1007/s00227008-1047-3.

Berge, J., Heggland, K., Lønne, O.J., et al., 2015. First records of Atlantic mackerel (Scomber scombrus) from the Svalbard archipelago, Norway, with possible explanations for the extension of its distribution. Arctic 68, 54-61. http://dx.doi. org/10.14430/arctic4455.

Berge, J., Johnsen, G., Nilsen, F., et al., 2005. Ocean temperature oscillations enable reappearance of blue mussels Mytilus edulis to Svalbard after a 1000 year absence. Mar. Ecol. Prog. Ser. 303, 167-175.

Berge, J., Johnsen, G., Nilsen, F., et al., 2006. The Mytilus edulis population in Svalbard: how and why. Mar. Ecol. Prog. Ser. 309, 305-306.

Berge, J., Varpe, Ø., Moline, M.A., et al., 2012. Retention of ice-associated amphipods: possible consequences for an ice-free Arctic Ocean. Biol. Lett. 8, 1012-1015. http://dx.doi.org/10.1098/rsbl.2012.0517.

Berline, L., Spitz, Y.H., Ashjian, C.J., et al., 2008. Euphausiid transport in the Western Arctic Ocean. Mar. Ecol. Prog. Ser. 360, 163-178.

Beszczynska-Möller, A., Woodgate, R.A., Lee, C., et al., 2011. A synthesis of exchanges through the main oceanic gateways to the Arctic Ocean. The Changing Arctic Ocean: Special Issue on the International Polar Year (20072009). Oceanography, vol. 24, pp. 82-99.

Beuchel, F., Lønne, O.J., 2002. Population dynamics of the sympagic amphipods Gammarus wilkitzkii and Apherusa glacialis in sea ice north of Svalbard. Polar Biol. 25, 241-250.

Biddle, L.C., Kaiser, J., Heywood, K.J., Thompson, A.F., Jenkins, A., 2015. Ocean glider observations of iceberg-enhanced biological production in the northwestern Weddell Sea. Geophys. Res. Lett. 42, 459-465. http://dx.doi.org/10.1002/ 2014GL062850.

Blacker, R.W., 1957. Benthic animals as indicators of hydrographic conditions and climatic change in Svalbard waters. Fish. Invest. (Series 2) 20, 1-49.

Blacker, R.W., 1965. Recent changes in the benthos of the West Spitsbergen fishing grounds. Spec. Publ. Int. Commis. Northwest Atlant. Fish. 6, 791-794.

Blain, S., Obernosterer, I., Quéguiner, B., Trull, T.W., Herndl, G., 2015. KEOPS 2: Kerguelen Ocean and Plateau compared Study 2. Biogeosciences 12 (KEOPS2 Special Issue), 1893-1906.

Bluhm, B.A., Gradinger, R., 2008. Regional variability in food availability for arctic marine mammals. Ecol. Appl. 18, S77-S96.

Boertman, D., Mosbech, A., 1998. Distribution of little auk (Alle alle) breeding colonies in Thule District, northwest Greenland. Polar Biol. 19, 206-210.

Böning, C.W., Dispert, A., Visbeck, M., et al., 2008. The response of the Antarctic Circumpolar Current to recent climate change. Nat. Geosci. 12, 864-869.

Born, E.W., Wiig, Ø., Thomassen, J., 1997. Seasonal and annual movements of radiocollared polar bears (Ursus maritimus) in Northeast Greenland. J. Mar. Syst. 10, 67-77.

Bortolotto, E., Bucklin, A., Mezzavilla, M., et al., 2011. Gone with the currents: lack of genetic differentiation at the circum-continental scale in the Antarctic krill Euphausia superba. BMC Genet. 12, 32. http://dx.doi.org/10.1186/1471-2156$12-32$.

Bost, C.A., Cotté, C., Bailleul, C.F., et al., 2009a. The importance of oceanographic fronts to marine birds and mammals of the southern oceans. J. Mar. Syst. 78, 363-378.

Bost, C.A., Thiebot, J.B., Pinaud, D., Cherel, Y., Trathan, P.N., 2009b. Where do penguins go during the inter-breeding period? Using geolocation to track the winter dispersion of the Macaroni penguin. Biol. Lett. 5, 473-476. http://dx.doi. org/10.1098/rsbl.2009.0265.

Bouchard, C., Fortier, L., 2011. Circum-arctic comparison of the hatching season of polar cod Boreogadus saida: a test of the freshwater winter refuge hypothesis, Prog. Oceanogr. 90, 105-116.

Boyd, I., 2002. Estimating food consumption of marine predators: Antarctic fur seals and macaroni penguins. J. Appl. Ecol. 39, 103-119.

Bracegirdle, T.J., Connolley, W.M., Turner, J., 2008. Antarctic climate change over the twenty first century. J. Geophys. Res.: Atmos. 113 (D3). http://dx.doi.org/ $10.1029 / 2007 j d 008933$.

Bracegirdle, T.J., Shuckburgh, E., Sallee, J.-B., et al., 2013. Assessment of surface winds over the Atlantic, Indian, and Pacific Ocean sectors of the Southern Ocean in CMIP5 models: historical bias, forcing response, and state dependence. J. Geophys. Res. 118, 547-562. http://dx.doi.org/10.1002/jgrd.50153.

Bradstreet, M.S.W., Cross, W.E., 1982. Trophic relationships at High Arctic ice edges. Arctic 35, 1-12.

Bradstreet, M.S.W., Finley, K.J., Sekerak, A.D., et al., 1986. Aspects of the Biology of Arctic Cod (Boreogadus saida) and its Importance in Arctic Marine Food Chains. Canadian Technical Report of Fisheries and Aquatic Sciences No. 1491. 193 pp. 
Braham, H.W., Fraker, M.A., Kragman, B.D., 1980. Spring migration of the Western Arctic population of bowhead whales. Mar. Fish. Rev. 42 (9-10), 51-57.

Brey, T., Gerdes, D., 1997. Is Antarctic benthic biomass really higher than elsewhere? Antarct. Sci. 9, 266-267.

Brey, T., Klages, M., Dahm, C., et al., 1994. Antarctic benthic diversity. Nature 368, 297.

Briggs, J.C., 2008. The North Atlantic Ocean: need for proactive management. Fisheries 33, 180-185.

Briggs, J.C., Bowen, B.W., 2012. A realignment of marine biogeographic provinces with particular reference to fish distributions. J. Biogeogr. 39, 12-30.

Brinkmeyer, R., Knittel, K., Jürgens, J., et al., 2003. Diversity and structure of bacterial communities in Arctic versus Antarctic pack ice. Appl. Environ. Microbiol. 69, 6610-6619.

Brooks, C.F., 1938. The warming Arctic. Meteorol. Mag. 73, 29-32.

Cai, M., 2005. Dynamical amplification of polar warming. Geophys. Res. Lett. 32. http://dx.doi.org/10.1029/2005GL024481.

Campbell, R.G., Sherr, E.B., Ashjian, C.J., et al., 2009. Mesozooplankton prey preference and grazing impact in the western Arctic Ocean. Deep-Sea Res. Part II 56, 1274-1289.

Carmack, E., Chapman, D.C., 2003. Wind-driven shelf/basin exchange on an Arctic shelf: the joint roles of ice cover extent and shelf-break bathymetry. Geophys. Res. Lett. 30. http://dx.doi.org/10.1029/2003GL017526.

Carmack, E., Barber, D., Christensen, J., et al., 2006. Climate variability and physical forcing of the food webs and the carbon budget on Panarctic shelves. Prog. Oceanogr. 71, 145-181.

Carmack, E., Winsor, P., Williams, W., 2015. The contiguous Panarctic riverine coastal domain: a unifying concept. Prog. Oceanogr. 139, 13-23. http://dx.doi. org/10.1016/j.pocean.2015.07.014.

Cherniawsky, J.Y., Crawford, W.R., Nikitin, O.P., Carmack, E.C., 2005. Bering Strait transports from satellite altimetry. J. Mar. Res. 63, 887-900.

Choi, D.-H., Kug, J.-S., Kwon, W.-T., et al., 2010. Arctic Oscillation responses to greenhouse warming and role of synoptic eddy feedback. J. Geophys. Res.: Atmos. 115, D17103.

Christiansen, J.S., Sparboe, M., Sæther, B.-S., Siikavuopio, S.I., 2015. Thermal behavior and the prospect spread of an invasive benthic top predator into the Euro-Arctic shelves. Divers. Distrib. 21, 1004-1013.

Church, J.A., Gregory, J.M., White, N.J., et al., 2011. Understanding and projecting sea level change. Oceanography 24, 130-143.

Clarke, A., 1996. Benthic marine habitats in Antarctica. Antarct. Res. Ser. 70, $123-$ 133.

Clarke, A., Meredith, M.P., Wallace, M., et al., 2008. Seasonal and interannual variability in temperature, chlorophyll and macronutrients in northern Marguerite Bay, Antarctica. Deep-Sea Res. Part II 55, 1988-2006.

Clarke, A., Murphy, E.J., Meredith, M.P., et al., 2007. Climate change and the marine ecosystem of the western Antarctic Peninsula. Philos. Trans. R. Soc. B: Biol. Sci. 362, 149-166.

Clem, K.R., Fogt, R.L., 2013. Varying roles of ENSO and SAM on the Antarctic Peninsula climate in austral spring. J. Geophys. Res.: Atmos. 118 (20). http://dx. doi.org/10.1002/jgrd.50860.

Clough, L.M., Renaud, P.E., Ambrose Jr., W.G., 2005. Impacts of water depth, sediment pigment concentration, and benthic macrofaunal biomass on sediment oxygen demand in the western Arctic Ocean. Can. J. Fish. Aquat. Sci. 62, 1756-1765.

Coachman, L.K., Aagaard, K., 1981. Re-evaluation of water transports in the vicinity of Bering Strait. In: Hood, D.W., Calder, J.A. (Eds.), The Eastern Bering Sea Shelf: Oceanography and Resources, vol. 1. National Oceanic and Atmospheric Administration, Washington, DC, pp. 95-110.

Cochrane, S.K.J., Densienko, S.G., Renaud, P.E., et al., 2009. Benthic fauna and productivity regimes in the Barents Sea - ecological implications in a changing Arctic. J. Sea Res. 61, 222-233.

Collins, M.A., Brickle, P., Brown, J., Belchier, M., 2010. The Patagonian toothfish: biology, ecology and fishery. Adv. Mar. Biol. 58, 227-300. http://dx.doi.org/ 10.1016/s0065.2881(10)58004.0.

Collins, M.A., Stowasser, G., Fielding, S., et al., 2012. Latitudinal and bathymetric patterns in the distribution and abundance of mesopelagic fish in the Scotia Sea. Deep-Sea Res. Part II 59-60, 189-198.

Collins, M.A., Xavier, J.C., Johnston, N., et al., 2008. Patterns in the distribution of myctophid fish in the northern Scotia Sea ecosystem. Polar Biol. 31, 837-851.

Comiso, J.C., Gordon, A.L., 1987. Recurring polynyas over the Cosmonaut Sea and the Maud Rise. J. Geophys. Res. 92, 2819-2833.

Comiso, J.C., Kwok, R., Martin, S., Gordon, A.L., 2011. Variability and trends in sea ice extent and ice production in the Ross Sea. J. Geophys. Res.: Oceans 116. http:// dx.doi.org/10.1029/2010jc006391.

Constable, A.J., Melbourne-Thomas, J., Corney, S.P., et al., 2014. Climate change and Southern Ocean ecosystems I: how changes in physical habitats directly affect marine biota. Glob. Change Biol. 20, 3004-3025.

Costa, D.P., Crocker, D.E., 1996. Marine mammals of the Southern Ocean. In: Ross, R. M., Hofmann, E.E, Quetin, L.B. (Eds.), Foundations for Ecological Research West of the Antarctic Peninsula. American Geophysical Union, Washington, DC. http://dx.doi.org/10.1029/AR070p0287.

Costa, D.P., Huckstadt, L.A., Crocker, D.E., et al., 2010. Approaches to studying climatic change and its role on the habitat selection of Antarctic pinnipeds. Integr. Comp. Biol. 50, 1018-1030.

Costanzo, G., Zagami, G., Crescenti, N., et al., 2002. Naupliar development of Stephos longipes (Copepoda: Calanoida) from the annual sea ice of Terra Nova Bay, Antarctica. J. Crustac. Biol. 22, 855-860.
Coyle, K.O., Hunt Jr., G.L., Decker, M.B., Weingartner, T.J., 1992. Murre foraging, epibenthic sound scattering and tidal advection over a shoal near St. George Island, Bering Sea. Mar. Ecol. Prog. Ser. 83, 1-14.

Croxall, J.P., Trathan, P.N., Murphy, E.J., 2002. Environmental change and Antarctic seabird populations. Science 297, 1510-1514.

Cushing, D., 1982. Climate and Fisheries. Academic Press, London. 373 pp.

Daase, M., Falk-Petersen, S., Varpe, Ø., et al., 2013. Timing of reproductive events in the marine copepod Calanus glacialis: a pan-Arctic perspective. Can. J. Fish. Aquat. Sci. 70, 871-884. http://dx.doi.org/10.1139/cjfas-2012-0401.

Dahlheim, M., Bray, T., Braham, H., 1980. Vessel survey for bowhead whales in the Bering and Chukchi Seas, June-July 1978. Mar. Fish. Rev. 42 (9-10), 51-57.

Dahms, H.-U., Bergmans, M., Schminke, H.K., 1990. Distribution and adaptations of sea ice inhabiting Harpacticoida Crustacea Copepoda of the Weddell Sea Antarctica. Mar. Ecol. 11, 207-226.

Dalpadado, P., Bogstad, B., 2004. Diet of juvenile cod (age 0-2) in the Barents Sea in relation to food availability and cod growth. Polar Biol. 27, 140-154.

Dalpadado, P., Mowbray, F., 2013. Comparative analysis of feeding ecology of capelin from two shelf ecosystems, off Newfoundland and in the Barents Sea. Prog. Oceanogr. 114, 97-105.

Dalpadado, P., Ellertsen, B., Melle, W., Skjoldal, H.R., 2012a. Summer distribution patterns and biomass estimates of macrozooplankton and micronekton in the Nordic Seas. Sarsia 83, 103-116.

Dalpadado, P., Ingvaldsen, R.B., Stige, L.C., et al., 2012b. Climate effects on Barents Sea ecosystem dynamics. ICES J. Mar. Sci. 69. http://dx.doi.org/10.1093/icesjms/ fss063.

Daly, K.L. 1990. Overwintering development, growth, and feeding of larval Euphausia superba in the Antarctic marginal ice zone. Limnol. Oceanogr. 35, $1564-1576$.

Daly, K.L., 2004. Overwintering growth and development of larval Euphausia superba: an interannual comparison under varying environmental conditions west of the Antarctic Peninsula. Deep-Sea Res. Part II 51, 2139-2168.

Daly, K.L., Macaulay, M.C., 1991. The influence of physical and biological mesoscale dynamics on the seasonal distribution and behavior of Euphausia superba in the Antarctic marginal ice zone. Mar. Ecol. Prog. Ser. 79, 37-66.

Damerau, M., Matschiner, M., Salzburger, W., Hanel, R., 2012. Comparative population genetics of seven notothenioid fish species reveals high levels of gene flow along ocean currents in the southern Scotia Arc, Antarctica. Polar Biol. 35, 1073-1086. http://dx.doi.org/10.1007/s00300-012-1155-x.

Damerell, G.M., Heywood, K.J., Stevens, D.P., 2013. Direct observations of the Antarctic circumpolar current transport on the northern flank of the Kerguelen Plateau. J. Geophys. Res. 118, 1333-1348.

Danielson, S.L., Eisner, L., Ladd, C., in press. Water masses, macronutrients, and phytoplankton standing crop in the northern Bering and Chukchi Seas of late summer 2012 and 2013. Deep-Sea Res. Part II. http://dx.doi.org/10.1016/j. dsr2.2016.05.024 (in press).

Danielson, S., Hedstrom, K., Aagaard, K., et al., 2012b. Wind-induced reorganization of the Bering shelf circulation. Geophys. Res. Lett. 39, L08601. http://dx.doi.org/ 10.1029/2012GL051231.

Danielson, S.L., Weingartner, T., Aagaard, K., et al., 2012a. Circulation on the centra Bering Sea shelf, July 2008 to July 2010. J. Geophys. Res.: Oceans 117, C10003. http://dx.doi.org/10.1029/2012JC008303.

Danielson, S.L., Weingartner, T.J., Hedstrom, K.S., et al., 2014. Coupled wind-forced controls of the Bering-Chukchi shelf circulation and Bering Strait throughflow: Ekman transport, continental shelf waves, and variations of the Pacific-Arctic sea surface height gradient. Prog. Oceanogr. 125, 40-61.

Darling, K.F., Wade, C.M., Stewart, I.A., et al., 2000. Molecular evidence for genetic mixing of Arctic and Antarctic subpolar populations of planktonic foraminifers Nature 405, 43-47.

David, C., Lange, B., Krumpen, T., Schaafsma, F., van Franeker, J.A., Flores, H., 2016 Under-ice distribution of polar cod Boreogadus saida in the central Arctic Ocean and their association with sea-ice habitat properties. Polar Biol. 39, 981-994.

Dayton, P.K., Mordida, B.J., Bacon, F., 1994. Polar marine communities. Am. Zool. 34, 90-99.

De Broyer, C., Koubbi, P. (Eds.), 2014. SCAR Biogeographic Atlas of the Southern Ocean. SCAR, Cambridge, UK. 498 pp.

Deibel, D., Daly, K.L., 2007. Zooplankton processes in Arctic and Antarctic polynyas. In: Smith, W.O., Jr., Barber, D. (Eds.), Polynyas: Windows into Polar Oceans. Elsevier Oceanography Series 74, pp. 271-322.

Delord, K., Pinet, P., Pinaud, D., et al., 2016. Species-specific foraging strategies and segregation mechanisms of sympatric Antarctic fulmarine petrels throughout the annual cycle. Ibis 158, 569-586.

De Santana, C.N., Rozenfeld, A.F., Marquet, P.A., Duarte, C.M., 2013. Topological properties of polar food webs. Mar. Ecol. Prog. Ser. 474, 15-26.

Diekmann, B., Kuhn, G., 1999. Provenance and dispersal of glacial marine surface sediments in the Weddell Sea and adjoining areas, Antarctica: ice-rafting versus current transport. Mar. Geol. 158, 209-231.

Ding, Q., Steig, E.J., Dattisti, D.S., Küttel, M., 2011. Winter warming in West Antarctica caused by central tropical Pacific warming. Nat. Geosci. 4, 398-403.

Dinniman, M.S., Klink, J.M., 2004. A model study of circulation and cross-shelf exchange on the west Antarctic Peninsula continental shelf. Deep-Sea Res. Part II 51, 2003-2022.

Dinniman, M.S., Klinck, J.M., Hofmann, E.E., 2012. Sensitivity of Circumpolar Deep Water transport and ice shelf basal melt along the West Antarctic Peninsula to changes in the winds. J. Clim. 25, 4799-4816. http://dx.doi.org/10.1175/JCLI-D11-00307.1. 
Dinniman, M.S., Klinck, J.M., Smith, W.O., 2003. Cross-shelf exchange in a model of the Ross Sea circulation and biogeochemistry. Deep-Sea Res. Part II 50, 3103 3120.

Dinniman, M.S., Klinck, J.M., Smith, W.O., 2011. A model study of circumpolar deep water on the West Antarctic Peninsula and Ross Sea continental shelves. DeepSea Res. Part II 58, 1508-1523.

Divoky, G.J., Lukacs, P.M., Druckenmiller, M.L., 2015. Effects of recent decreases in arctic sea ice on an ice-associated marine bird. Prog. Oceanogr. 136 (SI), 151 161.

Dmitrenko, I.A., Polyakov, I.V., Kirillov, S.A., et al., 2006. Seasonal variability of Atlantic water on the continental slope of the Laptev Sea during 2002-2004. Earth Planet. Sci. Lett. 244, 735-743. http://dx.doi.org/10.1016/j. epsl.2006.01.067.

Dower, K.M., Lucas, M.I., Phillips, R., Dieckmann, G., Robinson, D.H., 1996 Phytoplankton biomass, P-I relationships and primary production in the Weddell Sea, Antarctica, during the austral autumn. Polar Biol. 16, 41-52.

Downes, S.M., Budnick, A.S., Sarmiento, J.L., Farneti, R., 2011. Impacts of wind stress on the Antarctic Circumpolar Current fronts and associated subduction. Geophys. Res. Lett. 38. http://dx.doi.org/10.1029/2011gl047668.

Downes, S.M., Hogg, A.M., 2013. Southern ocean circulation and eddy compensation in CMIP5 models. J. Clim. 26, 7198-7220. http://dx.doi.org/10.1175/jcli-d-1200504.1.

Drinkwater, K., 2006. The regime shift of the 1920s and 1930s in the North Atlantic Prog. Oceanogr. 68, 134-151.

Ducklow, H.W., Baker, K., Martinson, D.G., et al., 2007. Marine pelagic ecosystems: the West Antarctic Peninsula. Philos. Trans. R. Soc. B: Biol. Sci. 362, 67-94. http://dx.doi.org/10.1098/rstb.2006.

Duffy-Anderson, J.T., Blood, D.M., Cheng, W., et al., 2013. Combining field observations and modeling approaches to examine Greenland halibut (Reinhardtius hippoglossoides) early life ecology in the southeastern Bering Sea. J. Sea Res. 75, 96-109.

Duhamel, G., 1998. The pelagic fish community of the Polar Frontal Zone off the Kerguelen Islands. In: Prisco, G.D., Pisano, E., Clarke, A. (Eds.), Fishes of Antarctica. A Biological Overview. Springer, Milan, pp. 63-74.

Duhamel, G., Koubbi, P., Ravier, C., 2000. Day and night mesopelagic fish assemblages off the Kerguelen Islands (Southern Ocean). Polar Biol. 23, 106112.

Dunbar, R.B., Leventer, A.R., Mucciarone, D.A., 1998. Water column sediment fluxes in the Ross Sea, Antarctica: atmospheric and sea ice forcing. J. Geophys. Res. 103, 30741-30759.

Dunbar, R.B., Leventer, A., Stockton, W.L., 1989. Biogenic sedimentation in McMurdo Sound, Antarctica. Mar. Geol. 85, 155-179.

Dunton, K.H., Goodall, J.L., Schonberg, S.V., et al., 2005. Multi-decadal synthesis of benthic-pelagic coupling in the western arctic: role of cross-shelf advective processes. Deep-Sea Res. Part II 52, 3462-3477.

Dunton, K.H., Weingartner, T., Carmack, E.C., 2006. The nearshore western Beaufort Sea ecosystem: circulation and importance of terrestrial carbon in Arctic coasta food webs. Prog. Oceanogr. 71, 362-378. http://dx.doi.org/10.1016/j. pocean.2006.09.011.

Duprat, L.P.A.M., Bigg, G.R., Wilton, D.J., 2016. Enhanced Southern Ocean marine productivity due to fertilization by giant icebergs. Nat. Geosci. 9, 219-221. http://dx.doi.org/10.1038/ngeo2633.

Durner, G.M., Douglas, D.C., Mielson, R.M., et al., 2009. Predicting 21st-century polar bear habitat distribution from global climate models. Ecol. Monogr. 79, 25-58.

Eastman, J.T., 1993. Antarctic Fish Biology: Evolution in a Unique Environment. Academic Press, San Diego. 322 pp.

Eastman, J.T., 1997. Comparison of the Antarctic and Arctic fish faunas. Cybium 21 $335-352$.

Eastman, J.T., 2005. The nature of the diversity of Antarctic fishes. Polar Biol. 28, 93 107.

Ekwurzel, B., Schlosser, P., Mortlock, R.A., Fairbanks, R.G., 2001. River runoff, sea ice meltwater, and Pacific Water distribution and mean residence times in the Arctic Ocean. J. Geophys. Res. 106 (C5), 9075-9092.

Emery, W.J., Fowler, C.W., Maslanik, J.A., 1997. Satellite-derived maps of Arctic and Antarctic sea ice motion: 1988 to 1994. Geophys. Res. Lett. 24, 897-900.

Emmerson, L., Southwell, C., 2008. Sea ice cover and its influence on Adelie Penguin reproductive performance. Ecology 89, 2096-2102.

Everson, I., Kock, K.H., Parkes, G., 1997. Interannual variation in condition of the mackerel icefish. J. Fish Biol. 51, 146-154.

Everson, I., Parkes, G., Kock, K.H., Boyd, L., 1999. Variation in standing stock of the mackerel icefish Champsocephalus gunnari at South Georgia. J. Appl. Ecol. 36 591-603. http://dx.doi.org/10.1046/j.1365-2664.1999.00425.x.

Fach, B.A., Klinck, J.M., 2006. Transport of Antarctic krill (Euphausia superba) across the Scotia Sea. Part I: circulation and particle tracking simulations. Deep-Sea Res. Part I 53, 987-1010.

Fach, B.A., Hofmann, E.E., Murphy, E.J., 2006. Transport of Antarctic krill (Euphausic superba) across the Scotia Sea. Part II: krill growth and survival. Deep-Sea Res. Part I 53, 1011-1043.

Fahrbach, E., Rohardt, G., Schröder, M., Strass, V., 1994. Transport and structure of the Weddell Gyre. Ann. Geophys. 12, 840-855.

Falck, E., Kattner, G., Budéus, G., 2005. Disappearance of Pacific Water in the northwestern Fram Strait. Geophys. Res. Lett. 32, L14619. http://dx.doi.org/ 10.1029/2005GL023400.

Falco, P., Zambianchi, E., 2011. Near-surface structure of the Antarctic Circumpolar Current derived from World Ocean Circulation Experiment drifter data. J. Geophys. Res.: Oceans 116, C05003.
Falk-Petersen, S., Hagen, W., Kattner, G., et al., 2000. Lipids, trophic relationships, and biodiversity in Arctic and Antarctic krill. Can. J. Fish. Aquat. Sci. 57 (S3), 178-191.

Falk-Petersen, S., Mayzaud, P., Kattner, G., Sargent, J.R., 2009. Lipids and life strategy of Arctic Calanus. Mar. Biol. Res. 5, 18-39.

Falk-Petersen, S., Pavlov, V., Berge, J., et al., 2015. At the rainbow's end: high productivity fueled by winter upwelling along an Arctic shelf. Polar Biol. 38, 511. http://dx.doi.org/10.1007/s00300-014-1482-1.

Falk-Petersen, S., Pavlov, V., Timofeev, S., Sargent, J.R., 2007. Climate variability and possible effects on arctic food chains: the role of Calanus. In: Ørbæk, J.B., Kallenborn, R., Tombre, I., Hegseth, E.N., Falk-Petersen, S., Hoel, A.H. (Eds.), Arctic-Alpine Ecosystems and People in a Changing Environment. Springer Verlag, Berlin, pp. 147-166.

Flannery, B.P., 1984. Energy-balance models incorporating transport of thermal and latent energy. J. Atmos. Sci. 41, 414-421.

Flores, H., van Franeker, J.A., Siegel, V., et al., 2012. The association of Antarctic Krill Euphausia superba with the under-ice habitat. PLoS ONE 7 (2), e31775. http://dx. doi.org/10.1371/journal.pone.0031775.

Fogt, R.L., Zbacnik, E.A., 2014. Sensitivity of the Amundsen Sea low to stratospheric ozone depletion. J. Clim. 27, 9383-9400. http://dx.doi.org/10.1175/jcli-d-1300657.1.

Fortier, L., Gilbert, M., Ponton, D., et al., 1996. Impact of fresh water on subarctic coastal ecosystem under seasonal sea-ice cover (southeastern Hudson Bay, Canada). III. Feeding success of marine fish larvae. J. Mar. Syst. 7, 251-265.

Fossheim, M., Primicerio, R., Johannesen, E., et al., 2015. Recent warming leads to a rapid borealization of fish communities in the Arctic. Nat. Clim. Change 5, 673677.

Francis, J.A., Vavrus, S.J., 2012. Evidence linking Arctic amplification to extreme weather in mid-latitudes. Geophys. Res. Lett. 39, L06801. http://dx.doi.org/ 10.1029/2012GL051000.

Frey, K.E., Moore, G.W.K., Cooper, L.W., Grebmeier, J.M., 2015. Divergent patterns of recent sea ice cover across the Bering, Chukchi, and Beaufort seas of the Pacific Arctic Region. Prog. Oceanogr. 136, 32-49.

Frey, K.E., Perovich, D.K., Light, B., 2011. The spatial distribution of solar radiation under a melting Arctic sea ice cover. Geophys. Res. Lett. 38, L22501. http://dx. doi.org/10.1029/2011GL049421.

Friedlaender, A.S., Halpin, P.N., Qian, S.S., et al., 2006. Whale distribution in relation to prey abundance and oceanographic processes in shelf waters of the Western Antarctic Peninsula. Mar. Ecol. Prog. Ser. 317, 297-310.

Friedlaender, A.S., Johnston, D.W., Fraser, W.R., et al., 2011. Ecological niche modeling of sympatric krill predators around Marguerite Bay, Western Antarctic Peninsula. Deep-Sea Res. Part II 58, 1729-1740.

Frölicher, T.L., Sarmiento, J.L., Dunne, J.P., Krasting, J.P., Winton, M., 2014. Dominance of the Southern Ocean in anthropogenic carbon and heat uptake in CMIP5 models. J. Clim. 28, 862-886.

Fyfe, J.C., Saenko, O.A., 2005. Human-induced change in the Antarctic Circumpolar Current. J. Clim. 18, 3068-3073.

Gall, A.E., Day, R.H., Weingartner, T.J., 2013. Structure and variability of the marinebird community in the northeastern Chukchi Sea. Cont. Shelf Res. 67, 96-115.

Gardner, W.D., Richardson, M.J., Smith Jr., W.O., 2000. Seasonal patterns of water column particulate organic carbon and fluxes in the Ross Sea, Antarctica. DeepSea Res. Part II 47, 3423-3449.

Geoffroy, M., Majewski, A., LeBlanc, M., et al., 2016. Vertical segregation of age-0 and age-1+ polar cod (Boreogadus saida) over the annual cycle in the Canadian Beaufort Sea. Polar Biol. 39, 1023-1037.

Geoffroy, M., Robert, D., Darnis, G., Fortier, L., 2011. The aggregation of polar cod (Boreogadus saida) in the deep Atlantic layer of ice-covered Amundsen Gulf (Beaufort Sea) in winter. Polar Biol. 34, 1959-1971.

George, R.Y., 1977. Dissimilar and similar trends in Antarctic and Arctic marine benthos. In: Dunbar, M.J. (Ed.), Polar Oceans. Arctic Institute of North America, Calgary, pp. 391-408.

Gerringa, L.J.A., Alderkamp, A.-C., Laan, P., et al., 2012. Iron from melting glaciers fuels the phytoplankton blooms in Amundsen Sea (Southern Ocean): iron biogeochemistry. Deep-Sea Res. Part II 71-76, 16-31.

Gibson, G.A., Coyle, K.O., Hedstrom, K., Curchitser, E.N., 2013. A modeling study to explore on-shelf transport of oceanic zooplankton in the Eastern Bering Sea. J. Mar. Syst. 121-122, 47-64.

Gilchrist, H.G., Robertson, G.J. 2000, Observations of marine birds and mammals wintering at polynyas and ice edges in the Belcher Islands, Nunavut, Canada. Arctic 53, 61-68.

Giles, K.A., Laxon, S.W., Ridout, A.L., Wingham, D.J., Bacon, S., 2012. Western Arctic Ocean freshwater storage increased by wind-driven spin-up of the Beaufort Gyre. Nat. Geosci. 5, 194-197. http://dx.doi.org/10.1038/ngeo1379.

Gili, J.-M., Arntz, W.E., Palanques, A., et al., 2006. A unique assemblage of epibenthic sessile suspension feeders with archaic features in the High-Antarctic. Deep-Sea Res. Part II 53, 1029-1052.

Gili, J.-M., Coma, R., Orejas, C., et al., 2001. Are Antarctic suspension-feeding communities different from those elsewhere in the world? Polar Biol. 24, 473485.

Gille, S.T., 2002. Warming of the Southern Ocean since the 1950s. Science 295, $1275-1277$.

Gille, S.T., 2008. Decadal-scale temperature trends in the Southern Hemisphere Ocean. J. Clim. 21, 4749-4765.

Gladstone, R.M., Bigg, G.R., Nicholls, K.W., 2001. Iceberg trajectory modelling and meltwater injection in the Southern Ocean. J. Geophys. Res. 106 (C9), 1990319915. 
Gradinger, R.R., Bluhm, B.A., 2004. In-situ observations on the distribution and behavior of amphipods and Arctic cod (Boreogadus saida) under the sea ice of the High Arctic Canada Basin. Polar Biol. 27, 595-603.

Gradinger, R., Bluhm, B., Iken, K., 2010. Arctic sea-ice ridges - safe heavens for seaice fauna during periods of extreme ice melt? Deep-Sea Res. Part II 57, 86-95.

Graversen, R.G., Mauritsen, T., Tjernstrom, M., Kallen, E., Svensson, G., 2008. Vertical structure of recent Arctic warming. Nature 451, 53-54.

Grebmeier, J.M., 2012. Shifting patterns of life in the Pacific Arctic and sub-Arctic seas. Annu. Rev. Mar. Sci. 4, 63-78.

Grebmeier, J.M., Barry, J.P., 1991. The influence of oceanographic processes on pelagic-benthic coupling in polar regions: a benthic perspective. J. Mar. Syst. 2, 495-518.

Grebmeier, J.M., Bluhm, B.A., Cooper, L.W., et al., 2015. Ecosystem characteristics and processes facilitating persistent macrobenthic biomass hotspots and associated benthivory in the Pacific Arctic. Prog. Oceanogr. 136, 92-114.

Grebmeier, J.M., Cooper, L.W., Feder, H.M., Sirenko, B.I., 2006a. Ecosystem dynamics of the Pacific-influenced Northern Bering and Chukchi Seas in the Amerasian Arctic. Prog. Oceanogr. 71, 331-361.

Grebmeier, J.M., Overland, J.E., Moore, S.E., et al., 2006b. A major ecosystem shift in the northern Bering Sea. Science 311, 1461-1464.

Greene, C.H., Pershing, A.J., 2007. Climate drives sea change. Science 315, 1084.

Griffiths, H.J., Whittle, R.J., Roberts, S.J., Belchier, M., Linse, K., 2013. Antarctic crabs: invasion or endurance? PLoS ONE 8 (7), e66981. http://dx.doi.org/10.1371/ journal.pone.0066981.

Gutt, J., Bertler, N., Bracegirdle, T.J., et al., 2015. The Southern Ocean ecosystem under multiple climate change stresses - an integrated circumpolar assessment. Glob. Change Biol. 21, 1434-1453.

Gutt, J., Starmans, A., Dieckmann, G., 1996. Impact of iceberg scouring on polar benthic habitats. Mar. Ecol. Prog. Ser. 137, 311-316.

Gutt, J., Starmans, A., Dieckmann, G., 1998. Phytodetritus deposited on the Antarctic shelf and upper slope: its relevance for the benthic system. J. Mar. Syst. 17, 435444.

Hamilton, S.G., de la Guardia, L.C., Derocher, A.E., et al., 2014. Projected polar bear sea ice habitat in the Canadian Arctic Archipelago. PLoS ONE 9, 113746.

Hanchet, S.M., Rickard, G.J., Fenaughty, J.M., et al., 2015. A hypothetical life cycle for Antarctic toothfish (Dissostichus mawsoni) in the Ross Sea region. CCAMLR Sci. J. Sci. Commit. Commis. Conserv. Antarct. Mar. Living Resour. 15, 35-53.

Harding, A.M.A., Kitaysky, A.S., Hamer, K.C., et al., 2009. Impacts of experimentally increased foraging effort on the family: offspring sex matters. J. Anim. Behav. 78, 321-328.

Hauck, J., Völker, C., Wang, T., et al., 2013. Seasonally different carbon flux changes in the Southern Ocean in response to the Southern Annular Mode. Glob. Biogeochem. Cycles 27, 1236-1245.

Havforskningsrapporten, 2015. Polartorsk, Fisken og Havet, Special issue 1. p. 178. ISSN: 08020620 (in Norwegian).

Heerah, K., Andrews-Goff, V., Williams, G., et al., 2013. Ecology of Weddell seals during winter: influence of environmental parameters on their foraging behaviour. Deep-Sea Res. Part II 88-89, 23-33.

Heide-Jørgensen, M.P., Laidre, K.L., Nielsen, N.H., et al., 2013. Winter and spring diving behavior of bowhead whales relative to prey. Anim. Biotelem. 1, 1-15. http://dx.doi.org/10.1186/2050-3385-1-15.

Held, I.M., Soden, B.J., 2006. Robust responses of the hydrological cycle to global warming. J. Clim. 19, 5686-5699.

Hempel, G., 1985. Antarctic marine food webs. In: Siegfried, W.R., Condy, P.R., Laws, R.M. (Eds.), Antarctic Nutrient Cycles and Food Webs. Springer-Verlag, Berlin, pp. 266-270.

Herraiz-Borreguero, L., Coleman, R., Allison, I., et al., 2015. Circulation of modified Circumpolar Deep Water and basal melt beneath the Amery Ice Shelf, East Antarctica. J. Geophys. Res.: Oceans 120, 3098-3112.

Hewitt, R.P., Watkins, J., Naganobu, M., et al., 2004. Variation in the biomass density and demography of Antarctic krill in the vicinity of the South Shetland Islands during the 1999/2000 austral summer. Deep-Sea Res. Part II 51, 1215-1236.

Highsmith, R.C., Coyle, K.O., Bluhm, B.A., Kona, B., 2006. Gray whales in the Bering and Chukchi Seas. In: Estes, J.A., DeMaster, D.P., Doak, D.F., Williams, T.M., Brownell, R.L., Jr. (Eds.), Whales, Whaling and Ocean Ecosystems. UC Press, Santa Cruz, CA, pp. 303-313.

Hirche, H.J., 1991. Distribution of dominant calanoid copepod species in the Greenland Sea during late fall. Polar Biol. 11, 351-362.

Hirche, H.J., Kosobokova, K., 2007. Distribution of Calanus finmarchicus in the northern North Atlantic and Arctic Ocean - expatriation and potential colonization. Deep-Sea Res. Part II 54, 2729-2747.

Hobbs, W.R., Massom, R., Stammerjohn, S., et al., 2016. A review of recent changes in Southern Ocean sea ice, their drivers and forcings. Glob. Planet. Change 143, 228-250. http://dx.doi.org/10.1016/j.gloplacha.2016.06.008.

Hobson, K.A., Ambrose Jr., W.G., Renaud, P.E., 1995. Sources of primary production, benthic-pelagic coupling, and trophic relationships within the Northeast Water Polynya: insights from $\delta^{13} \mathrm{C}$ and $\delta^{15} \mathrm{~N}$ analysis. Mar. Ecol. Prog. Ser. 128, 1-10.

Hodal, H., Kristiansen, S., 2008. The importance of small-celled phytoplankton in spring blooms at the marginal ice zone in the northern Barents Sea. Deep-Sea Res. Part II 55, 2176-2185.

Hofmann, E.E., Hüsrevoglu, Y.S., 2003. A circumpolar modeling study of habitat control of Antarctic krill (Euphausia superba) reproductive success. Deep-Sea Res. Part II 50, 3121-3142.

Hofmann, E.E., Murphy, E.J., 2004. Advection, krill, and Antarctic marine ecosystems. Antarct. Sci. 16, 487-499. http://dx.doi.org/10.1017/ s0954102004002275.
Hofmann, E.E., Klinck, J.M., Locarnini, R.A., et al., 1998. Krill transport in the Scotia Sea and environs. Antarct. Sci. 10, 406-415.

Hogg, A.M., Meredith, M.P., Blundell, J.R., Wilson, C., 2008. Eddy heat flux in the Southern Ocean: response to variable wind forcing. J. Clim. 21, 608-620.

Hogg, A.M., Meredith, M.P., Chambers, D.P., et al., 2015. Recent trends in the Southern Ocean eddy field. J. Geophys. Res.: Oceans 120, 257-267. http://dx.doi. org/10.1002/2014jc010470.

Holland, P.R., Kwok, R., 2012. Wind-driven trends in Antarctic sea-ice drift. Nat. Geosci. 5, 872-875.

Hollowed, A.B., Planque, B., Loeng, H., 2013. Potential movement of fish and shellfish stocks from the sub-Arctic to the Arctic Ocean. Fish. Oceanogr. 22 355-370.

Hop, H., Gjøsæter, H., 2013. Polar cod (Boreogadus saida) and capelin (Mallotus villosus) as key species in marine food webs of the Arctic and the Barents Sea. Mar. Biol. Res. 9, 878-894. http://dx.doi.org/10.1080/17451000.2013.775458.

Hop, H., Pavlova, O., 2008. Distribution and biomass transport of ice amphipods in drifting sea ice around Svalbard. Deep-Sea Res. Part II 55, 2292-2307.

Hop, H., Falk-Petersen, S., Svendsen, H., et al., 2006. Physical and biological characteristics of the pelagic system across Fram Strait to Kongsfjorden. Prog. Oceanogr. 71, 182-231.

Hop, H., Mundy, C.J., Gosselin, M., et al., 2011. Zooplankton boom and ice amphipod bust below melting sea ice in the Amundsen Gulf, Arctic Canada. Polar Biol. 34, 1947-1958. http://dx.doi.org/10.1007/s00300-011-0991-4.

Hop, H., Poltermann, M., Lønne, O.J., et al., 2000. Ice amphipod distribution relative to ice density and under-ice topography in the northern Barents Sea. Polar Biol 23, 357-367.

Hopcroft, R.R., Kosobokova, K.N., Pinchuk, A.I., 2010. Zooplankton community patterns in the Chukchi Sea during summer 2004. Deep-Sea Res. Part II 57, 27 39.

Horne, E.P., 1985. Ice-induced vertical circulation in an Arctic fiord. J. Geophys. Res. 90, 1078-1086.

Horner, R., Ackley, S.F., Dieckmann, G.S., et al., 1992. Ecology of sea ice biota 1. Habitat, terminology, and methodology. Polar Biol. 12, 417-427.

Hu, A., Otto-Bliesner, B.L., Meehl, G.A., et al., 2008. Response of thermohaline circulation to freshwater forcing under present-day and LGM conditions. J. Clim. 21, 2239-2258.

Hunt Jr., G.L., Harrison, N.M., 1990. Foraging habitat and prey taken by Least Auklets at King Island, Alaska. Mar. Ecol. Prog. Ser. 65, 141-150.

Hunt Jr., G.L., Megrey, B.A., 2005. Comparison of the biophysical and trophic characteristics of the Bering and Barents Seas. ICES J. Mar. Sci. 62, $1245-1255$.

Hunt Jr., G.L., Nettleship, D.N., 1988. Seabirds of high-latitude northern and southern environments. Proceedings of the 19th Int'l Ornithological Congress, Ottawa, vol. 1, pp. 1143-1155.

Hunt Jr., G.L., Schneider, D.C., 1987. Scale dependent processes in the physical and biological environment of marine birds. In: Croxall, J. (Ed.), Seabirds: Feeding Biology and Role in Marine Ecosystems. Cambridge U. Press, pp. 7-41.

Hunt Jr., G.L., Blanchard, A.L., Boveng, P., et al., 2013. The Barents and Chukchi Seas: comparison of two Arctic shelf ecosystems. J. Mar. Syst. 109-110, 43-68.

Hunt Jr., G.L., Coyle, K.O., Eisner, L., et al., 2011. Climate impacts on eastern Bering Sea food webs: a synthesis of new data and an of the Oscillating Control Hypothesis. ICES J. Mar. Sci. 68, 1230-1243.

Hunt Jr., G.L., Heinemann, D., Everson, I., 1992. Distributions and predator-prey interactions of macaroni penguins, Antarctic fur seals and Antarctic krill near Bird Island, South Georgia. Mar. Ecol. Prog. Ser. 86, 15-30.

Hunt, Jr., G.L., Ressler, P.H., Gibson, G.A., et al., in press. Euphausiids in the Eastern Bering Sea: A synthesis of recent studies of euphausiid production, consumption and population control. Deep-Sea Res. II. http://dx.doi.org/10. 1016/j.dsr2.2015.10.007.

Hunt Jr., G.L., Russell, R.W., Coyle, K.O., Weingartner, T., 1998. Comparative foraging ecology of planktivorous auklets in relation to ocean physics and prey availability. Mar. Ecol. Prog. Ser. 167, 241-259.

Huntley, M.E., Niiler, P.P., 1995. Physical control of population dynamics in the Southern Ocean. ICES J. Mar. Sci. 52, 457-468.

Hwang, Y.-T., Frierson, D.M.W., Kay, J.E., 2011. Coupling between Arctic feedbacks and changes in poleward energy transport. Geophys. Res. Lett. 38, L17704. http://dx.doi.org/10.1029/2011GL048546.

Ikeda, T., Thomas, P.G., 1987. Longevity of the Antarctic krill (Euphausia superba Dana) based on laboratory experiment. Proc. Natl. Inst. Polar Res. Symp. Polar Biol. 1, 56-62.

Ingvaldsen, R.B., 2005. Width of the North Cape Current and location of the Polar Front in the western Barents Sea. Geophys. Res. Lett. 32, L16603. http://dx.doi. org/10.1029/2005GL023440.

IPCC, 2013. Climate change 2013: the physical science basis. In: Stocker, T.F., Qin, D., Plattner, G.-K., Tignor, M., Allen, S.K., Boschung, J., Nauels, A., Xia, Y.l., Bex, V. Midgley, P.M. (Eds.), Contribution of Working Group I to the Fifth Assessment Report of the Intergovernmental Panel on Climate Change. Cambridge University Press, Cambridge, United Kingdom and New York, NY, USA. 1535 pp.

Isla, E., Gerdes, D., Palanques, A., Gili, J.-M., Arntz, W., 2006a. Particle fluxes and tides near the continental ice edge on the eastern Weddell Sea shelf. Deep-Sea Res. Part II 53, 866-874.

Isla, E., Gerdes, D., Palanques, A., et al., 2009. Downward particle fluxes, wind and a phytoplankton bloom over a polar continental shelf: a stormy impulse for the biological pump. Mar. Geol. 259, 59-72.

Isla, E., Masqué, P., Palanques, A., et al., 2004. Sedimentation of biogenic constituents during the last century in western Bransfield and Gerlache 
Straits, Antarctica: a relation to currents, primary production, and sea floor relief. Mar. Geol. 209, 265-277.

Isla, E., Rossi, S., Palanques, A., et al., 2006b. Organic matter in marine sediment from the eastern Weddell Sea (Antarctica): high nutritive value in a high benthic-biomass environment. J. Mar. Syst. 60, 255-267.

Isoguchi, O., Kawamura, H., Kono, T., 1997. A study on wind-driven circulation in the subarctic North Pacific using TOPEX/POSEIDON altimeter data. J. Geophys. Res.: Oceans 102 (C6), 12457-12468.

Jacobs, S.S., 1991. On the nature and significance of the Antarctic Slope Front. Mar. Chem. 35, 9-24.

Jacobs, S.S., Giulivi, C.F., Mele, P.A., 2002. Freshening of the Ross Sea during the late 20th century. Science 297, 386-389.

Janko, K., Lecointre, G., DeVries, A., et al., 2007. Did glacial advances during the Pleistocene influence differently the demographic histories of benthic and pelagic Antarctic shelf fishes? - Inferences from intraspecific mitochondrial and nuclear DNA sequence diversity. BMC Evol. Biol. 7, 220. http://dx.doi.org 10.1186/1471-2148-7-220.

Jarvis, T., Kelly, N., Kawaguchi, S., et al., 2010. Acoustic characterisation of the broadscale distribution and abundance of Antarctic krill (Euphausia superba) off East Antarctica (30-80 degrees E) in January-March 2006. Deep-Sea Res. Part II 57, SI 916-SI 933.

Jaschnov, W.A., 1970. Distribution of Calanus species in the seas of the northern hemisphere. Int. Rev. Gesamten Hydrobiol. 55, 197-212.

Jay, C.V., Fishbach, A.S., Kochnev, A.A., 2012. Walrus areas of use in the Chukchi Sea during sparse sea ice cover. Mar. Ecol. Prog. Ser. 468, 1-13.

Jenkins, A., Dutrieux, P., Jacobs, S.S., et al., 2010. Observations beneath Pine Island Glacier in West Antarctica and implications for its retreat. Nat. Geosci. 3, 468 472. http://dx.doi.org/10.1038/NGEO890.

Ji, R.B., Ashjian, C.J., Campbell, R.G., et al., 2012. Life history and biogeography of Calanus copepods in the Arctic Ocean: an individual-based modeling study. Prog. Oceanogr. 96, 40-56. http://dx.doi.org/10.1016/j.pocean.2011.10.001.

Ji, R., Jin, M., Varpe, Ø., 2013. Sea ice phenology and timing of primary production pulses in the Arctic Ocean. Glob. Change Biol. 19, 734-741.

Joiris, C.R., 2000. Summer at-sea distribution of seabirds and marine mammals in polar ecosystems: a comparison between the European Arctic seas and the Weddell Sea, Antarctica. J. Mar. Syst. 27, 267-276.

Jones, D.O.B., Bett, B.J., Tyler, P.A., 2007. Depth-related changes in the arctic epibenthic megafaunal assemblages of Kangerdlugssuaq, East Greenland. Mar. Biol. Res. 3, 191-204. http://dx.doi.org/10.1080/17451000701455287.

Jones, E.P. Anderson, L.G. Swift, J.H., 1998. Distribution of Atlantic and Pacific waters in the upper Arctic Ocean: implications for circulation. Geophys. Res. Lett. 25, 765-768.

Jones, E.P., Swift, J.H., Anderson, L.G., et al., 2003. Tracing Pacific water in the North Atlantic Ocean. J. Geophys. Res. 108 (C4), 3116. http://dx.doi.org/10.1029/ 2001JC001141.

Karcher, M., Gerdes, R., Kauker, F., Koberle, C., Yashayaev, I., 2005. Arctic Ocean change heralds North Atlantic freshening. Geophys. Res. Lett. 32, L21606. http:// dx.doi.org/10.1029/2005GL023861.

Karnovsky, N.J., Hunt Jr., G.L., 2002. Estimation of carbon flux to dovekies (Alle alle) in the North Water. Deep-Sea Res. Part II 49, 5117-5130.

Karnovsky, N.J., Harding, A., Walkusz, W., et al., 2010. Foraging distributions of little auks across the Greenland Sea: implications of present and future Arctic climate change. Mar. Ecol. Prog. Ser. 415, 283-293.

Karnovsky, N.J., Kwaśniewski, S., Wesławski, J.M., et al., 2003. Foraging behavior of little auks in a heterogeneous environment. Mar. Ecol. Prog. Ser. 253, 289-303.

Karsten, R.H., Marshall, J., 2002. Constructing the residual circulation of the ACC from observations. J. Phys. Oceanogr. 32, 3315-3327.

Kawaguchi, S., Satake, M., 1994. Relationship between recruitment of the Antarctic krill and the degree of ice cover near the South Shetland Islands. Fish. Sci. 60, $123-124$.

Kedra, M., Moritz, C. Choy, E.S., et al., 2015. Status and trends in the structure of Arctic benthic food webs. Polar Res. 34, 23775. http://dx.doi.org/10.3402/polar. v34.23775.

Kędra, M., Renaud, P.E., Andrade, H., et al., 2013. Benthic community structure diversity and productivity in the shallow Barents Sea bank (Svalbard Bank). Mar. Biol. 160, 805-819. http://dx.doi.org/10.1007/s00227-012-2135-y.

Kim, S.L., Oliver, J.S., 1989. Swarming benthic crustaceans in the Bering and Chukchi seas and their relation to geographic patterns in gray whale feeding. Can. J. Zool 67, 1531-1542.

Kirkwood, J.M., 1993. Zooplankton Community Dynamics and Diel Vertica Migration in Ellis Fjord, Vestfold Hills, Antarctica PhD Thesis. Monash University, Victoria, Australia.

Kjesbu, O.S., Bogstad, B., Devine, J.A., et al., 2014. Synergies between climate and management for Atlantic cod fisheries at high latitudes. Proc. Natl. Acad. Sci. $111,3478-3483$

Knox, G.A., 1994. Studies of Polar Research: The Biology of the Southern Ocean. Cambridge University Press, New York. 444 pp.

Knox, G.A., 2007. Biology of the Southern Ocean. CRC Press. 621 pp.

Kock, K.H., 1992. Antarctic Fish and Fisheries. Cambridge University Press, Cambridge, UK. 375 pp.

Kock, K.H., 1994. Variations in the diet composition and feeding intensity of Mackerel icefish Camposocephalus gunnari at South Georgia (Antarctic). Mar. Ecol. Prog. Ser. 108, 43-57.

Koenigk, T., Brodeau, L., 2014. Ocean heat transport into the Arctic in the twentieth and twenty-first century in EC-Earth. Clim. Dyn, 42, 3101-3120.
Koenigk, T., Brodeau, L., Graversen, R.G., et al., 2013. Arctic climate change in 21st century CMIP5 simulations with EC-Earth. Clim. Dyn. 40, 2719-2743. http://dx. doi.org/10.1007/s00382-012-1505-y.

Kooyman, G.L., 2002. Evolutionary and ecological aspects of some Antarctic and sub-Antarctic penguin distributions. Oecologia 130, 485-495.

Korb, R.E., Whitehouse, M.J., Ward, P., 2004. SeaWiFS in the Southern Ocean: spatial and temporal variability in phytoplankton biomass around South Georgia. Deep-Sea Res. Part II 51, 99-116.

Kosobokova, K., Hirche, H.-J., 2000. Zooplankton distribution across the Lomonosov Ridge, Arctic Ocean: species inventory, biomass and vertical structure. Deep-Sea Res. Part I 47, 2029-2060.

Kosobokova, K., Hirche, H.-J., 2009. Biomass of zooplankton in the eastern Arctic Ocean - a base line study. Prog. Oceanogr. 82, 265-280.

Kosobokova, K.N., Hopcroft, R.R., 2010. Diversity and vertical distribution of mesozooplankton in the Arctic's Canada Basin. Deep-Sea Res. Part II 57, 96-110.

Kosobokova, K., Hopcroft, R.R., Hirche, H., 2011. Patterns of zooplankton diversity through the depths of the Arctic's central basins. Mar. Biodivers. 41, 29-50.

Kottmeier, S.T., Sullivan, C.W., 1987. Late winter primary production and bacterial production in sea-ice and seawater west of the Antarctic Peninsula. Mar. Ecol. Prog. Ser. 36, 287-298.

Kovacs, K.M., Lydersen, C., Overland, J.E., Moore, S.E., 2011. Impacts of changing seaice conditions on Arctic marine mammals. Mar. Biodivers. 41, 181-194. http:// dx.doi.org/10.1007/s12526-010-0061-0.

Kreutz, K.J., Mayewski, P.A., Pittalwala, I.I., et al., 2000. Sea level pressure variability in the Amundsen Sea region inferred from a West Antarctic glaciochemical record. J. Geophys. Res. 105, 4047-4059.

Kropuenske, L.R., Mills, M.M., van Dijken, G.L., et al., 2009. Photophysiology in two major Southern Ocean phytoplankton taxa: photoprotection in Phaeocystis antarctica and Fragilariopsis cylindrus. Limnol. Oceanogr. 54, 1176-1196.

Kug, J.-S., Choi, D.-H., Jin, F.-F., et al., 2010. Role of synoptic eddy feedback on polar climate responses to the anthropogenic forcing. Geophys. Res. Lett. 37, L14704.

Kwok, R., 2009. Outflow of Arctic sea ice into the Greenland and Barents Seas: 1979-2007. J. Clim. 22, 2438-2457. http://dx.doi.org/10.1175/2008JCLI2819.1.

Kwok, R., Comiso, J.C., 2002a. Spatial patterns of variability in Antarctic surface temperature: connections to the Southern Hemisphere Annular Mode and the Southern Oscillation. Geophys. Res. Lett. 29. http://dx.doi.org/10.1029/ 2002gl015415.

Kwok, R., Comiso, J.C., 2002b. Southern Ocean climate and sea ice anomalies associated with the Southern Oscillation. J. Clim. 15, 487-501. http://dx.doi.org/ 10.1175/1520-0442(2002)015<0487: socasi>2.0.co;2.

Kwok, R., Untersteiner, N., 2011. The thinning of Arctic sea ice. Phys. Today 64, $36-$ 41.

Laidre, K.L., Heide-Jørgensen, M.P., 2012. Spring partitioning of Disko Bay, West Greenland, by Arctic and Subarctic baleen whales. ICES J. Mar. Sci. 69, 12261233. http://dx.doi.org/10.1093/icesjms/fss095.

Laidre, K.L., Heagerty, P., Heide-Jørgensen, M.P., et al., 2009. Sexual segregation of common minke whales (Balaenoptera acutorostrata) and sex ratio of catches in Greenland. ICES J. Mar. Sci. 66, 2253-2266.

Laidre, K.L., Heide-Jørgensen, M.P., Heagerty, P., et al., 2010. Spatial associations between large baleen whales and their prey in West Greenland. Mar. Ecol. Prog. Ser. 402, 269-284

Laidre, K.L., Stern, H., Kovacs, K.M., et al., 2015. Arctic marine mammals, population status, habitat loss, and with conservation recommendations for the 21st century. Conserv. Biol. 29, 36-41.

La Mesa, M., Eastman, J.T., 2012. Antarctic silverfish: life strategies of a key species in the high-Antarctic ecosystem. Fish Fish. 13, 241-266. http://dx.doi.org/ 10.1111/j.1467-2979.2011.00427.x.

Landa, C.S., Ottersen, G., Sundby, S., et al., 2014. Recruitment, distribution boundary and habitat temperature of an arcto-boreal gadoid in a climatically changing environment: a case study on Northeast Arctic haddock (Melanogrammus aeglefinus). Fish. Oceanogr. 23, 506-520. http://dx.doi.org/10.1111/fog.12085.

Langematz, U., Kunze, M., 2008. Dynamical changes in the Arctic and Antarctic stratosphere during spring. In: Brönnimann, S., Luterbacher, J., Ewan, T., Diaz, H. F. Stolarski, R.S., Neu, U. (Eds.), Climate Variability and Extremes during the Past 100 Years. Advances in Global Change Research 33, pp. 293-301.

Langen, P.L., Alexeev, V.A., 2007. Polar amplification as a preferred response in an idealized aquaplanet GCM. Clim. Dyn. 29, 305-317.

Langlais, C.E., Rintoul, S.R., Zika, D.K., 2015. Sensitivity of Antarctic Circumpolar Current transport and eddy activity to wind patterns in the Southern Ocean. J. Phys. Oceanogr. 45, 1051-1067.

Laurel, B.J., Spencer, M., Iseri, P., Copeman, L.A., 2016a. Temperature-dependent growth and behavior of juvenile Arctic cod (Boreogadus saida) and co-occurring North Pacific gadids. Polar Biol. 39, 1127-1135. http://dx.doi.org/10.1007/ s00300-015-1761-5.

Laurel, B.J., Spencer, M., Iseri, P., et al., 2016b. Temperature-dependent growth and behavior of juvenile Arctic cod (Boreogadus saida) and co-occurring North Pacific gadids. Polar Biol. 39, 1127-1135.

Lawver, L.A., Gahagan, L.M., 2003. Evolution of Cenozoic seaways in the circum Antarctic region. Palaeogeogr. Palaeoclimatol. Palaeoecol. 198, 11-38.

Lefebvre, W., Goosse, H., Timmermann, R., Fichefet, T., 2004. Influence of the Southern Annular Mode on the sea ice-ocean system. J. Geophys. Res.: Oceans 109 (C9). http://dx.doi.org/10.1029/2004jc002403.

Le Fouest, V., Babin, M., Tremblay, J.-É., 2013. The fate of riverine nutrients on Arctic shelves. Biogeosciences 10, 3661-3677. 
Leu, E., Mundy, C.J., Assmy, P., et al., 2015. Arctic spring awakening - steering principles behind phenology of vernal ice algal blooms. Prog. Oceanogr. 139, $151-170$.

Leu, E., Søreide, J.E., Hessen, D.O., et al., 2011. Consequences of changing sea-ice cover for primary and secondary producers in the European Arctic shelf seas: timing, quantity, and quality. Prog. Oceanogr. 90, 18-32.

Lien, V.S., Vikebø, F.B., Skagseth, Ø., 2013. One mechanism contributing to covariability of the Atlantic inflow branches to the Arctic. Nat. Commun. 4, 1488. http://dx.doi.org/10.1038/ncomms2505.

Lizotte, M.P., 2001. The contributions of sea ice algae to Antarctic marine primary production. Am. Zool. 41, 57-73.

Loeb, V.J., Santora, J.A., 2012. Population dynamics of Salpa thompsoni near the Antarctic Peninsula: growth rates and interannual variations in reproductive activity (1993-2009). Prog. Oceanogr. 96, 93-107.

Loeb, V.J., Santora, J.A., 2015. Climate variability and spatiotemporal dynamics of five Southern Ocean krill species. Prog. Oceanogr. 134, 93-122. http://dx.doi. org/10.1016/j.pocean.2015.01.002.

Loeb, V., Siegel, V., Holm-Hansen, O., et al., 1997. Effects of sea-ice extent and krill or salp dominance on the Antarctic food web. Nature 387, 897-900.

Loeng, H., 1991. Features of the physical oceanographic conditions of the Barents Sea. Polar Res. 10, 5-8.

Loeng, H., Drinkwater, K., 2007. Climate variability and the ecosystems of the Barents and Norwegian Seas. Deep-Sea Res. Part II 54, 2478-2500.

Loeng, H., Brander, K., Carmack, E., et al., 2005. Marine systems. In: Arctic Climate Impact Assessment. Cambridge University Press, pp. 451-538 (Chapter 8).

Loeng, H., Ozhigin, V., Ardlandsvik, B., 1997. Water fluxes through the Barents Sea. ICES J. Mar. Sci. 54, 310-317.

Logerwell, E., Busby, M., Carothers, C., et al., 2015. Fish communities across a spectrum of habitats in the western Beaufort Sea and Chukchi Sea. Prog. Oceanogr. 136, 115-132.

Longhurst, A., 1998. Ecological Geography of the Sea. Academic Press, p. 398.

Lønne, O.J., Gabrielsen, G.W., 1992. Summer diet of seabirds feeding in sea-icecovered waters near Svalbard. Polar Biol. 12, 685-692.

Lønne, O.J., Gulliksen, B., 1989. Size, age and diet of polar cod, Boreogadus saida (Lepechin 1773), in ice covered waters. Polar Biol. 9, 187-191.

Lønne, O.J., Gulliksen, B., 1991. On the distribution of sympagic macro-fauna in the seasonally ice covered Barents Sea. Polar Biol. 11, 457-469.

Lovenduski, N.S., Gruber, N., 2005. Impact of the Southern Annular Mode on Southern Ocean circulation and biology. Geophys. Res. Lett. 32 (11), 1-4.

Lovvorn, J.R., Anderson, E.M., Rocha, A.R., et al., 2014. Variable wind, pack ice, and prey dispersion affect the long-term adequacy of protected areas for an Arctic sea duck. Ecol. Appl. 24, 396-412.

Lowry, L.F., Sheffield, G., George, J.C., 2004. Bowhead whale feeding in the Alaskan Beaufort Sea, based on stomach contents analyses. J. Cetacean Res. Manage. 6, 215-223.

Macdonald, R.W., Harner, T., Fyfe, J., Loeng, H., Weingartner, T., 2003. AMAP Assessment 2002: The Influence of Global Change on Contaminant Pathways to, within and from the Arctic. Arctic Monitoring and Assessment Programme (AMAP), Oslo, Norway. 65 pp.

Mackey, A.P., Atkinson, A., Hill, S.L., et al., 2012. Antarctic macrozooplankton of the southwest Atlantic sector and Bellingshausen Sea: baseline historical distributions (Discovery Investigations, 1928-1935) related to temperature and food, with projections for subsequent ocean warming. Deep-Sea Res. Part II 59$60,130-146$.

Markus, T., Stroeve, J.C., Miller, J., 2009. Recent changes in Arctic sea ice melt onset, freezeup, and melt season length. J. Geophys. Res. 114, C12024. http://dx.doi. org/10.1029/2009JC005436.

Marrari, M., Daly, K.L., Hu, C., 2008. Spatial and temporal variability of SeaWiFS derived chlorophyll distributions west of the Antarctic Peninsula: implications for krill production. Deep-Sea Res. Part II 55, 377-392.

Marrari, M., Daly, K.L., Timonin, A., Semenova, T., 2011. The zooplankton of Marguerite Bay, Western Antarctic Peninsula - part I: abundance, distribution, and population response to variability in environmental conditions. Deep-Sea Res. Part II 58, 1599-1613.

Marshall, G., Orr, A., van Lipzing, N.P.M., King, J.O., 2006. The impact of a changing southern hemisphere annular mode on Antarctic Peninsula summer temperatures. J. Climatol. 19, 4388-5404.

Marshall, J., Speer, K., 2012. Closure of the meridional overturning circulation through Southern Ocean upwelling. Nat. Geosci. 5, 171-181.

Marshall, J., Armour, K.C., Scott, J.R., et al., 2014. The ocean's role in polar climate change: asymmetric Arctic and Antarctic responses to greenhouse gas and ozone forcing. Philos. Trans. R. Soc. Lond. A: Math. Phys. Eng. Sci. 372 (2019), 20130040.

Massom, R.A., Stammerjohn, S.E., 2010. Antarctic sea ice change and variability physical and ecological importance. Polar Sci. 4, 149-186.

Massom, R.A., Harris, P.T., Michael, K.J., Potter, M.J., 1998. The distribution and formative processes of latent-heat polynyas in East Antarctica. Ann. Glaciol. 27, 420-426.

Massom, R.A., Hill, K., Barbraud, C., Adams, N., et al., 2009. Fast ice distribution in Adélie Land, East Antarctica: interannual variability and implications for emperor penguins Aptenodytes forsteri. Mar. Ecol. Prog. Ser. 374, 243-257.

Mathis, J.T., Pickart, R.S., Hansell, D.A., et al., 2007. Eddy transport of organic carbon and nutrients from the Chukchi Shelf: impact on the upper halocline of the western Arctic Ocean. J. Geophys. Res.: Oceans 112 (C5), C05011.
McBride, M.M., Dalpadado, P., Drinkwater, K.F., et al., 2014. Krill, climate, and contrasting future scenarios for Arctic and Antarctic fisheries. ICES J. Mar. Sci. 71, 1934-1955. http://dx.doi.org/10.1093/icesjms/fsu002.

McClelland, J.W., Dery, S.J., Peterson, B.J., Holmes, R.M., Wood, E.F., 2006. A panArctic evaluation of changes in river discharge during the latter half of the 20th century. Geophys. Res. Lett. 33, L06715. http://dx.doi.org/10.1029/ 2006GL025753.

McClintic, M.A., DeMaster, D.J., Thomas, C.J., Smith, C.R., 2008. Testing the FOODBANCS Hypothesis: determining seasonal variations in near-bottom particle flux, bioturbation intensity, and the feeding continuity and selectivity of deposit feeders. Deep-Sea Res. Part II 55, 2425-2437.

McGillicuddy, D.J., Sedwick, P.N., Dinniman, M.S., et al., 2015. Iron supply and demand in an Antarctic shelf ecosystem. Geophys. Res. Lett. 42. http://dx.doi. org/10.1002/2015GL065727.

Megrey, B.A., Link, J.S., Hunt Jr., G.L., Moksness, E., 2009. Comparative marine ecosystem analysis: applications, opportunities, and lessons learned. Prog. Oceanogr. 81, 2-9.

Mei, Z.P., Legendre, L., Gratton, Y., et al., 2002. Physical control of spring-summer phytoplankton dynamics in the North Water, April-July 1998. Deep-Sea Res. Part II 49, 4959-4982.

Meijers, A., Klocker, A., Bindoff, N., et al., 2010. The circulation and water masses of the Antarctic shelf and continental slope between $30-80^{\circ}$ E. Deep-Sea Res. Part II 57, 723-737.

Meijers, A.J.S., Shuckburgh, E., Bruneau, N., et al., 2012. Representation of the Antarctic Circumpolar Current in the CMIP5 climate models and future changes under warming scenarios. J. Geophys. Res. 117, C12008. http://dx.doi.org/ 10.1029/2012JC008412.

Melling, H., Agnew, T.A., Falkner, K.K., et al., 2008. Fresh-water fluxes via Pacific and Arctic Outflows across the Canadian Polar Shelf. In: Dickson, R.R., Meincke, J. Rhines, P. (Eds.), Arctic-Subarctic Ocean Fluxes, Defining the Role of the Northern Seas in Climate. Springer, Dordrecht, The Netherlands, pp. 193-247.

Melling, H., Gratton, Y., Ingram, G., 2001. Ocean circulation within the North Water Polynya of Baffin Bay. Atmos. Oceans 39, 301-325.

Melnikov, I.A., 1997. The Arctic Sea Ice Ecosystem. Gordon and Breach Science Publishers, Amsterdam. 204 pp.

Melnikov, I.A., Kolosova, E.G., Welch, H.E., Zhitina, L.S., 2002. Sea ice biological communities and nutrient dynamics in the Canada Basin of the Arctic Ocean. Deep-Sea Res. Part I 49, 1623-1649.

Meredith, M.P., Hogg, A.M., 2006. Circumpolar response of Southern Ocean eddy activity to a change in the Southern Annular Mode. Geophys. Res. Lett. 33 (16). http://dx.doi.org/10.1029/2006gl026499.

Meredith, M.P., Venables, H.J., Clarke, A., et al., 2013. The freshwater system west of the Antarctic Peninsula: spatial and temporal changes. J. Clim. 26, 1669-1684.

Metz, C., 1995. Seasonal-variation in the distribution and abundance of Oithona and Oncaea species (Copepoda, Crustacea) in the southeastern Weddell Sea, Antarctica. Polar Biol. 15, 187-194.

Mincks, S.L., Smith, C.R., DeMaster, D.J., 2005. Persistence of labile organic matter and microbial biomass in Antarctic shelf sediments: evidence of a sediment "food bank". Mar. Ecol. Prog. Ser. 300, 3-19.

Minnett, P.J., Bignami, F., Bohm, E., et al., 1997. A summary of the formation and seasonal progression of the Northeast Water Polynya. J. Mar. Syst. 10, 79-85.

Moffat, C., Beardsley, R.C., Owens, B., van Lipzig, N., 2008. A first description of the Antarctic Peninsula Coastal Current. Deep-Sea Res. Part II 55, 277-293.

Moline, M.A., Karnovsky, N.J., Brown, Z., et al., 2008. High latitude changes in ice dynamics and their impact on polar marine ecosystems. In: Ostfield, R.S. Schlesinger, W.H. (Eds.), The Year in Ecology and Conservation Biology. Annals of the New York Academy of Sciences 1134, pp. 267-319.

Montes-Hugo, M., Doney, S.C., Ducklow, H.W., et al., 2009. Recent changes in phytoplankton communities associated with rapid regional climate change along the Western Antarctic Peninsula. Science 323, 1470-1473.

Moore, J.K., Abbott, M.R., 2000. Phytoplankton chlorophyll distributions and primary production in the Southern Ocean. J. Geophys. Res. 105 (C12), $28709-28722$.

Moore, S.E., Huntington, H.P., 2008. Arctic marine mammals and climate change: impacts and resilience. Ecol. Appl. 18 (2), S157-S165.

Moore, S.E., Laidre, K.L., 2006. Analysis of sea ice trends scaled to habitats used by bowhead whales in the western Arctic. Ecol. Appl. 16, 932-944.

Moore, S.E., George, J.C., Coyle, K.O., et al., 1995. Bowhead whales along the Chukota coast in autumn. Arctic 48, 155-160.

Moran, S.B., Kelly, R.P., Hagstrom, K., et al., 2005. Seasonal changes in POC export flux in the Chukchi Sea and implications for water column-benthic coupling in Arctic shelves. Deep-Sea Res. Part II 52, 3427-3451.

Morata, N., Renaud, P.E., 2008. Sedimentary pigments in the western Barents Sea: a reflection of pelagic-benthic coupling? Deep-Sea Res. Part II 55, 2381-2389. http://dx.doi.org/10.1016/j.dsr2.2008.05.004.

Morison, J., Kwok, R., Peralta-Ferriz, C., et al., 2012. Changing Arctic Ocean freshwater pathways. Nature 481, 66-70.

Mueter, F.J., Dawe, E.G., Pálsson, Ó., 2012. Subarctic fish and crustacean populations - climate effects and trophic dynamics. Mar. Ecol. Prog. Ser. 469, 191-193.

Murawski, S.A., Steele, J.H., Taylor, P., et al., 2010. Why compare marine ecosystems? ICES J. Mar. Sci. 67, 1-9.

Murphy, E.J., Reid, K., 2001. Modelling Southern Ocean krill population dynamics: biological processes generating fluctuations in the South Georgia ecosystem. Mar. Ecol. - Prog. Ser. 217, 175-189. 
Murphy, E.J., Clarke, A., Abram, N.J., Turner, J., 2014. Variability of sea-ice in the northern Weddell Sea during the 20th century. J. Geophys. Res.: Oceans 119 (7) 4549-4572. http://dx.doi.org/10.1002/2013jc009511.

Murphy, E.J., Clarke, A., Symon, C., Priddle, J., 1995. Temporal variation in Antarctic sea-ice - analysis of a long-term fast-ice record from the South Orkney Islands. Deep-Sea Res. Part I 42, 1045-1062. http://dx.doi.org/10.1016/0967-0637(95) 00057-d.

Murphy, E.J., Hofmann, E.E., Watkins, J.L., et al., 2013. Comparison of the structure and function of Southern Ocean regional ecosystems: the Antarctic Peninsula and South Georgia. J. Mar. Syst. 109 (SI), 22-42.

Murphy, E.J., Thorpe, S.E., Watkins, J.L., Hewitt, R., 2004a. Modeling the krill transport pathways in the Scotia Sea: spatial and environmental connections generating the seasonal distribution of krill. Deep-Sea Res. Part II 51, 1435 1456.

Murphy, E.J., Trathan, P.N., Watkins, J.L., et al., 2007b. Climatically driven fluctuations in Southern Ocean ecosystems. Proc. R. Soc. B: Biol. Sci. 274 3057-3067.

Murphy, E.J., Watkins, J.L., Meredith, M.P., et al., 2004b. Southern Antarctic Circumpolar Current Front to the northeast of South Georgia: horizonta advection of krill and its role in the ecosystem. J. Geophys. Res.: Oceans 109, C01029.

Murphy, E.J., Watkins, J.L., Reid, K., et al., 1998. Interannual variability of the South Georgia marine ecosystem: biological and physical sources of variation in the abundance of krill. Fish. Oceanogr. 7, 381-390.

Murphy, E.J., Watkins, J.L., Trathan, P.N., et al., 2007a. Spatial and temporal operation of the Scotia Sea ecosystem: a review of large-scale links in a kril centred food web. R. Soc. Philos. Trans. Biol. Sci. 362, 113-148. http://dx.doi.org/ 10.1098/rstb.2006.1957.

Myers, P.G., Kulan, N., Ribergaard, M.H., 2007. Irminger water variability in the West Greenland Current. Geophys. Res. Lett. 34, L17601. http://dx.doi.org/10.1029/ 2007GL030419.

Nahrgang, J., Varpe, Ø., Korshunova, E., et al., 2014. Gender specific reproductive strategies of an Arctic key species (Boreogadus saida) and implications of climate change. PLoS ONE 9, e98452.

Nelson, R.J., Carmack, E.C., McLaughlin, F.A., Cooper, G.A., 2009. Penetration of Pacific zooplankton into the western Arctic Ocean tracked with molecula population genetics. Mar. Ecol. Prog. Ser. 381, 129-138.

Newman, P.A., Nash, E.R., Kawa, S.R., et al., 2006. When will the Antarctic ozone hole recover? Geophys. Res. Lett. 33, L12814.

Nicol, S., 2006. Krill, currents, and sea ice: Euphausia superba and its changing environment. Bioscience 56 (2), 111-120. http://dx.doi.org/10.1641/0006-3568 (2006)056[0111:kcasie]2.0.co;2

Nicol, S., Clarke, J., Romaine, S.J., et al., 2008a. Krill (Euphausia superba) abundance and Adelie penguin (Pygoscelis adeliae) breeding performance in the waters off the Bechervaise Island colony, East Antarctica in 2 years with contrasting ecological conditions. Deep-Sea Res. Part II 55, 540-557.

Nicol, S., Pauly, T., Bindoff, N.L., et al., 2000. Ocean circulation off east Antarctica affects ecosystem structure and sea-ice extent. Nature 406, 504-550. http://dx. doi.org/10.1038/35020053.

Nicol, S., Worby, A., Leaper, R., 2008b. Changes in the Antarctic sea ice ecosystem: potential effects on krill and baleen whales. Mar. Freshw. Res. 59, 361-382.

Niebauer, H.J., Bond, N.A., Yakunin, L.P., Plotnikov, V.V., 1999. An update on the climatology and sea ice of the Bering Sea. In: Loughlin, T.R., Ohtani, K. (Eds.) Dynamics of the Bering Sea: A Summary of Physical, Chemical, and Biological Characteristics, and a Synopsis of Research on the Bering Sea. North Pacific Marine Science Organization (PICES), University of Alaska Sea Grant, AK-SG-9903, Fairbanks, Alaska, USA, pp. 29-59.

Núñez-Riboni, I., Fahrbach, E., 2009. Seasonal variability of the Antarctic Coastal Current and its driving mechanisms in the Weddell Sea. Deep-Sea Res. Part I 56 1927-1941.

Nürnberg D, Wollenburg I. Dethleff, D, et al, 1994. Sediments in Arctic sea ice: implications for entrainment, transport and release. Mar. Geol. 119, 185-214.

Ogi, M., Rigor, I.G., 2013. Trends in Arctic sea ice and the role of atmospheric circulation. Atmos. Sci. Lett. 14, 97-101. http://dx.doi.org/10.1002/asl2.423.

Olivier, F., van Franeker, J.A., Creuwels, J.C.S., et al., 2005. Variations of snow petre breeding success in relation to sea-ice extent: detecting local response to largescale processes? Polar Biol. 28, 687-699.

Orejas, C., Gili, J.-M., Arntz, W.E., 2003. The role of small plankton communities in the diet of two Antarctic octocorals (Primnoisis antarctica and Primnoella sp.). Mar. Ecol. Prog. Ser. 250, 105-116.

Orsi, A.H., Whitworth, T., Nowlin, W.D., 1995. On the meridional extent and fronts of the Antarctic Circumpolar Current. Deep-Sea Res. Part I 42, 641-673. http://dx doi.org/10.1016/0967-0637(95)00021-w.

Oug, E., Cochrane, S.K.J., Sundet, J.H., Norling, K., Eilertsen, H.C., 2011. Effects of the invasive red king crab (Paralithodes camtschaticus) on soft-bottom fauna in Varangerfjorden, northern Norway. Mar. Biodivers, 41, 467-479.

Overland, J.E., 1986. Coastal jets in the lower atmosphere - comments. J. Phys Oceanogr. 16, 1006

Overland, J.E., Wang, M., 2013. When will the summer arctic be nearly sea ice free? Geophys. Res. Lett. 40, 2097-2101. http://dx.doi.org/10.1002/grl.50316.

Overland, J.E., Spillane, M.C., Percival, D.B., et al., 2004. Seasonal and regional variation of pan-Arctic surface air temperature over the instrumental record. J. Clim. 17, 3263-3281.

Overland, J.E., Wang, M., Walsh, J.E., et al., 2014. Future Arctic climate changes: adaptation and mitigation time scales. Earths Future 2, 68-74.
Overland, J.E., Wood, K.R., Wang, M., 2011. Warm Arctic, cold continents: climate impacts of the newly open Arctic Sea. Polar Res. 30, 15787. http://dx.doi.org/ 10.3402/polar.v30i0.15787.

Pabi, S., van Dijken, G.L., Arrigo, K.R., 2008. Primary production in the Arctic Ocean, 1998-2006. J. Geophys. Res. 113, C08005. http://dx.doi.org/10.1029/ 2007JC004578.

Pakhomov, E.A., Froneman, P.W., 1999a. Macroplankton/micronekton dynamics in the vicinity of the Prince Edward Islands (Southern Ocean). Mar. Biol. 134, $501-$ 515. http://dx.doi.org/10.1007/s002270050566.

Pakhomov, E.A., Froneman, P.W., 1999b. The Prince Edward Islands pelagic ecosystem, south Indian ocean: a review of achievements, 1976-1990. J. Mar. Syst. 18, 355-367. http://dx.doi.org/10.1016/s0924-7963(97)00112-7.

Pakhomov, E.A., Froneman, P.W., 2000. Composition and spatial variability of macroplankton and micronekton within the Antarctic Polar Frontal Zone of the Indian Ocean during austral autumn 1997. Polar Biol. 23, 410-419. http://dx. doi.org/10.1007/s003000050462.

Pakhomov, E.A., Froneman, P.W., Ansorge, I.J., Lutjeharms, J.R.E., 2000. Temporal variability in the physico-biological environment of the Prince Edward Islands (Southern Ocean). J. Mar. Syst. 26, 75-95. http://dx.doi.org/10.1016/s0924-7963 (00)00041-5.

Pakhomov, E.A., Perissinotto, R., McQuaid, C.D., 1996. Prey composition and daily rations of myctophid fishes in the Southern Ocean. Mar. Ecol. Prog. Ser. 134, $1-$ 14.

Palanques, A., Isla, E., Puig, P., et al., 2002. Annual evolution of downward particle fluxes in the Western Bransfield Strait (Antarctica) during the FRUELA project. Deep-Sea Res. Part II 49, 903-920.

Pálsson, Ó.K., Gislason, A., Guðfinnsson, H.G., et al., 2012. Ecosystem structure in the Iceland Sea and recent changes to the capelin (Mallotus villosus) population. ICES J. Mar. Sci. 69, 1242-1254.

Paquette, R.G., Bourke, R.H., 1981. Ocean circulation and fronts as related to ice melt-back in the Chukchi Sea. J. Geophys. Res. 86, 4215-4230.

Parada, C., Armstrong, D.A., Ernst, B., et al., 2010. Spatial dynamics of snow crab (Chionoecetes opilio) in the eastern Bering Sea-putting together the pieces of the puzzle. Bull. Mar. Sci. 86, 413-437.

Park, M.G., Yang, S.R., Kang, S.-H., et al., 1999. Phytoplankton biomass and primary production in the marginal ice zone of the northwestern Weddell Sea during austral summer. Polar Biol. 21, 251-261.

Patarnello, T., Barggelloni, L., Varotto, V., Battaglia, B., 1996. Krill evolution and the Antarctic Ocean currents: evidence of speciation as inferred by molecular data. Mar. Biol. 126, 603-608.

Paterson, J.T., Rotella, J.J., Arrigo, K., et al., 2015. Tight coupling of primary production and marine mammal reproduction in the Southern Ocean. Proc. R. Soc. B: Biol. Sci. 282. UNSP 20143137.

Pavlov, V., Pavlova, O., Korsnes, R., 2004. Sea ice fluxes and drift trajectories from potential pollution sources, computed with a statistical sea ice model of the Arctic Ocean. J. Mar. Syst. 48, 133-157. http://dx.doi.org/10.1016/j. jmarsys.2003.11.024.

Pease, C.H., 1980. Eastern Bering Sea ice processes. Mon. Weather Rev. 108, 20152023.

Peck, L.S., Webb, K.E., Bailey, D.M., 2004. Extreme sensitivity of biological function to temperature in Antarctic marine species. Funct. Ecol. 18, 625-630.

Pedersen, C.E., Falk, K., 2001. Chick diet of dovekies Alle alle in northwest Greenland. Polar Biol. 24, 53-58.

Pedersen, S.A., Ribergaard, M.H., Simonsen, C.S., 2005. Micro- and mesozooplankton in Southwest Greenland waters in relation to environmental factors. J. Mar. Syst. 56, 85-112.

Pedersen, T., Fossheim, M., 2008. Diet of 0-group stages of capelin (Mallotus villosus), herring (Clupea harengus) and cod (Gadus morhua) during spring and summer in the Barents Sea. Mar. Biol. 153, 1037-1046.

Perissinotto, R., McQuaid, C.D., 1992. Land-based predator impact on vertically migrating zooplankton and micronecton advected to a Southern Ocean archipelago. Mar. Ecol. Prog. Ser. 80, 15-27. http://dx.doi.org/10.3354/ meps080015.

Perissinotto, R., Lutjeharms, J.R.E., van Ballegooyen, R.C., 2000. Biological-physical interactions and pelagic productivity at the Prince Edward Islands, Southern Ocean. J. Mar. Syst. 24, 327-341. http://dx.doi.org/10.1016/s0924-7963(99) 00093-7.

Perovich, D., Meier, W., Tschudi, M., et al., 2015. Sea Ice. Arctic Report Card. <http:// www.arctic.noaa.gov/reportcard/sea_ice.html>

Peterson, I., Hamilton, J., Prinsenberg, S., Pettipas, R., 2012. Wind-forcing of volume transport through Lancaster Sound. J. Geophys. Res. 117, C11018. http://dx.doi. org/10.1029/2012JC008140.

Petitgas, P., Rijnsdorp, A.D., Dickey-Collas, M., et al., 2013. Impacts of climate change on the complex life cycles of fish. Fish. Oceanogr. 22, 121-139.

Petrik, C.M., Duffy-Anderson, J.T., Castruccio, F. et al., 2016. Modelled connectivity between Walleye Pollock (Gadus chalcogrammus) spawning and age-0 nursery areas in warm and cold years with implications for juvenile survival. ICES J. Mar. Sci. 73, 1890-1900.

Petrik, C.M., Duffy-Anderson, J.T., Mueter, F., et al., 2015. Biophysical transport model suggests climate variability determines distribution of walleye pollock early life stages in the Eastern Bering Sea through effects on spawning. Prog. Oceanogr. 138, 459-474. http://dx.doi.org/10.1016/j.pocean.2014.06.004.

Piatkowski, U., Rodhouse, P.G., White, M.G., et al., 1994. Nekton community of the Scotia Sea as sampled by the RMT 25 during austral summer. Mar. Ecol. Prog. Ser. 112, 13-28. 
Piatt, J.F., Springer, A.M., 2003. Advection, pelagic food webs and the biogeography of Beringia. Mar. Ornithol. 31, 141-154.

Pickart, R.S., Moore, G.W.K., Torres, D.J., et al., 2009. Upwelling on the continental slope of the Alaskan Beaufort Sea: storms, ice, and oceanographic response. J. Geophys. Res.: Oceans 114 (C1), C00A13. http://dx.doi.org/10.1029/ 2008JC005009.

Pickart, R.S., Schulze, L.M., Moore, G.W.K., et al., 2013. Long-term trends of upwelling and impacts on primary productivity in the Alaskan Beaufort Sea. Deep-Sea Res. Part I 79, 106-121. http://dx.doi.org/10.1016/j.dsr.2013.05.003.

Piepenburg, D., 1988. On the composition of the benthic-fauna of the Western Fram Strait. Berichte Polarforsc. 52, 1-4.

Piepenburg, D., Ambrose, W.G., Brandt, A., et al., 1997. Benthic community patterns reflect water column processes in the Northeast Water polynya (Greenland). J. Mar. Syst. 10, 467-482.

Piepenburg, D., Archambault, P., Ambrose Jr., W.G., et al., 2011. Towards a panArctic inventory of the species diversity of the macro- and megabenthic fauna of the Arctic shelf seas. Mar. Biodivers. 41, 51-70.

Piepenburg, D., Blackburn, T.H., von Dorrien, C.F., et al., 1995. Partitioning of benthic community respiration in the Arctic (Northwestern Barents Sea). Mar. Ecol. Prog. Ser. 118, 119-213.

Pike, D.G., Welch, H.E., 1990. Spatial and temporal distribution of sub-ice macrofauna in the Barrow Strait area, Northwest Territories. Can. J. Fish. Aquat. Sci. 47, 81-91.

Pinchuk, A.I., Coyle, K.O., Farley, E.V., et al., 2013. Emergence of the Arctic Themisto libellula (Amphipoda: Hyperiidae) on the southeastern Bering Sea shelf as a result of the recent cooling, and its potential impact on the pelagic food web. ICES J. Mar. Sci. 70, 1244-1254.

Piñones, A., Hofmann, E.E., Daly, K.L., et al., 2011. Lagrangian simulation of transport pathways and residence times along the western Antarctic Peninsula. Deep-Sea Res. Part II 58, 1524-1539.

Piñones, A., Hofmann, E.E., Daly, K.L., et al., 2013a. Modeling environmental controls on the transport and fate of early life stages of Antarctic krill (Euphausia superba) on the western Antarctic Peninsula continental shelf. Deep-Sea Res. Part I 82, 17-31.

Piñones, A., Hofmann, E.E., Daly, K.L., et al., 2013b. Modeling the remote and local connectivity of Antarctic krill populations along the western Antarctic Peninsula. Mar. Ecol. Prog. Ser. 481, 69-92. http://dx.doi.org/10.3354/ meps10256.

Piñones, A., Hofmann, E.E., Dinniman, M.S., Davis, L.B., 2016. Modeling the transport and fate of euphausiids in the Ross Sea. Polar Biol. 39, 177-187. http://dx.doi. org/10.1007/s00300-015-1798-5.

Pitman, R.L., Durban, J.W., 2010. Killer whale predation on penguins in Antarctica. Polar Biol. 33, 1589-1594.

Pitman, R.L., Durban, J.W., 2012. Cooperative hunting behavior, prey selectivity and prey handling by pack ice killer whales (Orcinus orca), type B, in Antarctic Peninsula waters. Mar. Mammal Sci. 28, 16-36.

Plötz, J., Weidel, H., Bersch, M., 1991. Winter aggregations of marine mammals and birds in the north-eastern Weddell Sea pack ice. Polar Biol. 11, 305-309.

Pollard, R.T., Salter, I., Sanders, R.J., et al., 2009. Southern Ocean deep-water carbon export enhanced by natural iron fertilization. Nature 457 (7229), 577-580.

Poltermann, M., 1998. Abundance, biomass and small-scale distribution of cryopelagic amphipods in the Franz Josef Land area (Arctic). Polar Biol. 20, $134-138$.

Pörtner, H.-O., 2010. Oxygen and capacity-limitation of thermal tolerance: a matrix for integrating climate-related stressor effects in marine ecosystems. J. Exp. Biol. 213, 881-893.

Pörtner, H.-O., 2012. Integrating climate-related stressor effects on marine organisms: unifying principles linking molecule to ecosystem-level changes. Mar. Ecol. Prog. Ser. 470, 273-290.

Pörtner, H.-O., Farrell, A.P., 2008. Physiology and climate. Science 322, 690-692.

Pörtner, H.-O., Peck, M.A., 2010. Climate change effects on fishes and fisheries: towards a cause-and-effect understanding. J. Fish Biol. 77, 1745-1779.

Prézelin, B.B., Hofmann, E.E., Mengelt, C., Klinck, J.M., 2000. The linkage between Upper Circumpolar Deep Water (UCDW) and phytoplankton assemblages on the west Antarctic Peninsula continental shelf. J. Mar. Res. 58, 165-202.

Proshutinsky, A., Krishfield, R., Timmermans, M.L., et al., 2009. Beaufort Gyre freshwater reservoir: state and variability from observations. J. Geophys. Res.: Oceans 114 (C1), C00A10.

Pusch, C., Hulley, P.A., Kock, K.H., 2004. Community structure and feeding ecology of mesopelagic fishes in the slope waters of King George Island (South Shetland Islands, Antarctica). Deep-Sea Res. Part I 51, 1685-1708.

Quéguinér, B., 2013. Iron fertilization and the structure of planktonic communities in high nutrient regions of the Southern Ocean. Deep-Sea Res. Part II 90, 43-54.

Quetin, L.B., Ross, R.M., 2003. Episodic recruitment in Antarctic krill Euphausia superba in Palmer LTER study region. Mar. Ecol. Prog. Ser. 259, 185-200.

Raiswell, R., Benning, L.G., Tranter, M., Tlulaczyk, S., 2008. Bioavailable iron in the Southern Ocean: the significance of the iceberg conveyor belt. Geochem. Trans. 9, 7. http://dx.doi.org/10.1186/1467-4866-9-7.

Raphael, M.N., 2007. The influence of atmospheric zonal wave three on Antarctic sea ice variability. J. Geophys. Res.: Atmos. 112 (D12). http://dx.doi.org/ 10.1029/2006jd007852.

Rass, T.S., 1968. Spawning and development of polar cod. Rapp. Procès-Verbeaux Réunions Conseil Int. l'Exploration Mer 158, 135-137.

Raymo, M.E., 1994. The initiation of northern hemisphere glaciation. Annu. Rev. Earth Planet. Sci. 22, 353-383.
Reigstad, M., Carroll, J., Slagstad, D., Ellingsen, I., Wassmann, P., 2011. Intra-regional comparison of productivity, carbon flux and ecosystem composition within the northern Barents Sea. Prog. Oceanogr. 90, 33-46.

Renaud, P.E., Lønne, O.J., Ottesen, C., et al., 2012. Is the poleward expansion by Atlantic cod and haddock threatening native polar cod, Boreogadus saida? Polar Biol. 35, 401-412.

Renaud, P.E., Morata, N., Carroll, M.L., et al., 2008. Benthic-pelagic coupling in the western Barents Sea: processes and time scales. Deep-Sea Res. Part II 55, 2372 2380. http://dx.doi.org/10.1024/j.dsr2.2008.05.017.

Renaud, P.E., Sejr, M.K., Bluhm, B.A., et al., 2015. The future of Arctic benthos: expansion, invasion, and biodiversity. Prog. Oceanogr. 139, 244-257. http://dx. doi.org/10.1016/j.pocean.2015.07.007.

Renner, A.H.H., Thorpe, S.E., Heywood, K.J., et al., 2012. Advective pathways near the tip of the Antarctic Peninsula: trends, variability and ecosystem implications. Deep-Sea Res. Part I 63, 91-101.

Renner, M., Salo, S., Kuletz, K.J., et al., 2016. Timing of ice retreat alters seabird abundances and distributions in the southeast Bering Sea. Royal Society. Biol. Lett. 12. http://dx.doi.org/10.1098/rsbl.2016.0276.

Rey, F., 2012. Declining silicate concentrations in the Norwegian and Barents Seas ICES J. Mar. Sci. 69, 208-212. http://dx.doi.org/10.1093/icesjms/fss007.

Rhines, P., Hakkinen, S., Josey, S.A., 2008. Is oceanic heat transport significant in the climate system? In: Dicksen, R.R., Meincke, J., Rhines, P. (Eds.), Arctic-Subarctic Ocean Fluxes. Springer, Dordrecht, The Netherlands, pp. 87-109.

Richar, J.I., Kruse, G.H., Curchitser, E., Hermann, A.J., 2014. Patterns in connectivity and retention of simulated Tanner crab (Chionoecetes bairdi) larvae in the eastern Bering Sea. Prog. Oceanogr. 138, 175-185. http://dx.doi.org/10.1016/j. pocean.2014.08.001.

Riebesell, U., Schloss, I., Smetacek, V., 1991. Aggregation of algae released from melting sea ice: implications for seeding and sedimentation. Polar Biol. 11, 239248.

Rigor, I.G., Wallace, J.M., Colony, R.L., 2002. On the response of sea ice to the Arctic Oscillation. J. Clim. 15, 2648-2668.

Rintoul, S., Hughes, C., Olbers, D., 2001. The Antarctic circumpolar current system. In: Siedler, G., Church, J., Gould, J. (Eds.), Ocean Circulation and Climate. Academic Press, New York, pp. 271-302.

Roach, A.T., Aagaard, K., Pease, C.H., et al., 1995. Direct measurements of transport and water properties through the Bering Strait. J. Geophys. Res. 100, 1844318457.

Robinson, C.H., 2001. Cold adaptation in Arctic and Antarctic fungi. New Phytol. 151 341-353.

Rode, K.D., Regehr, E.V., Douglas, D.C., et al., 2014. Variation in the response of an Arctic top predator experiencing habitat loss: feeding and reproductive ecology of two polar bear populations. Glob. Change Biol. 20, 76-88.

Rodhouse, P.G.K., Prince, P.A., Trathan, P.N., et al., 1996. Cephalopod community associated with mesoscale oceanographic features at the Antarctic Polar Front. Biol. Bull. 189 (2), 77-80.

Rogers, A.D., Johnston, N.M., Murphy, E.J., Clarke, A. (Eds.), 2012. Antarctic Ecosystems: An Extreme Environment in a Changing World. Blackwell Publishing Ltd., Oxford, UK. http://dx.doi.org/10.1002/9781444347241.

Rothrock, D.A., Percival, D.B., Wensnahan, M., 2008. The decline in arctic sea-ice thickness: separating the spatial, annual, and interannual variability in a quarter century of submarine data. J. Geophys. Res.: Oceans 113 (C5), C05003. http://dx.doi.org/10.1029/2007JC004252.

Rudels, B., Jones, E.P., Anderson, L.G., Kattner, G., 1994. On the intermediate depth waters of the Arctic Ocean. In: Johannessen, O.M., Muench, R.D., Overland, J.E. (Eds.), The Role of the Polar Oceans in Shaping the Global Climate, Geophysical Monographs, vol. 85. American Geophysical Union, Washington, pp. 33-46.

Rudels, B., Marnela, M., Eriksson, P., 2008. Constraints on estimating mass, heat and freshwater transports in the Arctic Ocean: an exercise. In: Dickson, R.R. Meincke, J., Rhines, P. (Eds.), Arctic-Subarctic Ocean Fluxes. Springer, Dordrecht The Netherlands, pp. 315-341.

Runge, J.A., Ingram, R.G., 1991. Under-ice feeding and diel migration by the planktonic copepods Calanus glacialis and Pseudocalanus minutus in relation to the ice algal production cycle in southeastern Hudson Bay, Canada. Mar. Biol. 108, 217-225.

Russell, R.W., Harrison, N.M., Hunt Jr., G.L., 1999. Foraging at a front: hydrography, zooplankton and avian planktivory in the northern Bering Sea. Mar. Ecol. Prog. Ser. 182, 77-93.

Saba, G.K., Fraser, W.R., Saba, V.S., 2014. Winter and spring controls on the summer food web of the coastal West Antarctic Peninsula. Nat. Commun. 5, 4318. http:// dx.doi.org/10.1038/ncomms5318.

Sallee, J.B., Shuckburgh, E., Bruneau, N., et al., 2013. Assessment of Southern Ocean water mass circulation and characteristics in CMIP5 models: historical bias and forcing response. J. Geophys. Res.: Oceans 118, 1830-1844. http://dx.doi.org/ 10.1002/jgrc.20135.

Sandø, A.B., Gao, Y., Langehaug, H.R., 2014. Poleward ocean heat transports, sea ice processes, and Arctic sea ice variability in NorESM1-M simulations. J. Geophys. Res.: Oceans 119, 2095-2108. http://dx.doi.org/10.1002/2013JC009435.

Sañé, E., Isla, E., Gerdes, D., Montiel, A., Gili, J.-M., 2012. Benthic macrofauna assemblages and biochemical properties of sediments in two Antarctic regions differently affected by climate change. Cont. Shelf Res. 35, 53-63.

Sañé, E., Isla, E., Pruski, A.M., et al., 2011. Diatom valve distribution and sedimentary fatty acid composition in Larsen Bay, Eastern Antarctic Peninsula. Cont. Shelf Res. 31, 1161-1168. 
Santora, J.A., 2014. Environmental determinants of top predator distribution within the dynamic winter pack ice zone of the northern Antarctic Peninsula. Polar Biol. 37, 1083-1097.

Sarmiento, J.L., Hughes, T.M.C., Stouffer, R.J., et al., 1998. Simulated response of the ocean carbon cycle to anthropogenic climate warming. Nature 393, 245-249.

Schauer, U., Beszczynska-Möller, A., Walczowski, W., et al., 2008. Variation of measured heat flow through the Fram Strait between 1997 and 2006. In: Dickson, R.R., Meincke, J., Rhines, P. (Eds.), Arctic-Subarctic Ocean Fluxes, Defining the Role of the Northern Seas in Climate. Springer, Dordrecht, The Netherlands, pp. 65-85.

Scheffer, A., 2013. Foraging Behaviour of King Penguins (Aptenodytes patagonicus) in Relation to Oceanography at South Georgia and Kerguelen PhD Thesis. Open University, UK.

Scheffer, A., Trathan, P.N., Collins, M., 2010. Foraging behaviour of King Penguins (Aptenodytes patagonicus) in relation to predictable mesoscale oceanographic eatures in the Polar Front Zone to the north of South Georgia. Prog. Oceanogr. $86,232-245$

Schlosser, P., Kromer, B., Ostlund, G., Ekwurzel, B., Bonisch, G., Loosl, H.H., Purtscher R. 1994. On the ${ }^{14} \mathrm{C}$ and ${ }^{39} \mathrm{Ar}$ distribution in the central Arctic Ocean: implications for deep water formation. Radiocarbon 36, 327-343.

Schmid, M.K., Piepenburg, D., Golikov, A.A., et al., 2006. Trophic pathways and carbon flux patterns in the Laptev Sea. Prog. Oceanogr. 71, 314-330.

Schneider, W., Budéus, G., 1994. The North East Water polynya (Greenland Sea). Polar Biol. 14, 1-9.

Schofield, O., Ducklow, H., Bernard, K., et al., 2013. Penguin biogeography along the West Antarctic Peninsula: testing the Canyon Hypothesis with Palmer LTER observations. Oceanography 26, 204-206.

Schwarz, J.N., Schodlok, M.P., 2008. Impact of drifting icebergs on surface phytoplankton biomass in the Southern Ocean: ocean colour remote sensing and in situ iceberg tracking. Deep-Sea Res. Part I 56, 1727-1741.

Schwegmann, S., Haas, C., Fowler, C., Gerdes, R., 2011. A comparison of satellitederived sea-ice motion with drifting-buoy data in the Weddell Sea, Antarctica. Ann. Glaciol. 52 (57), 103-110.

Screen, J.A., Simmonds, I., 2010. The central role of diminishing sea ice in recent Arctic temperature amplification. Nature 464, 1334-1337.

Screen, J.A., Gillett, N.P., Karpechko, A.Y., Stevens, D.P., 2010. Mixed layer temperature response to the Southern Annular Mode: mechanisms and mode representation. J. Clim. 23, 664-678.

Sen Gupta, A., Santoso, A., Taschetto, A.S., et al., 2009. Projected changes to the Southern Hemisphere ocean and sea ice in the IPCC AR4 climate models. J. Clim. 22, 3047-3078.

Serreze, M.C., Francis, J.A., 2006. The Arctic amplification debate. Clim. Change 76 241-264.

Serreze, M.C., Barrett, A.P., Slater, A.G., et al., 2006. The large-scale freshwater cycle of the Arctic. J. Geophys. Res.: Oceans 111, C11010. http://dx.doi.org/10.1029/ 2005JC003424.

Serreze, M.C., Holland, M.M., Stroeve, J., 2007. Perspectives on the Arctic's shrinking sea-ice cover. Science 315, 1533-1536.

Shelton, P.A., Hutchings, L., 1982. Transport of anchovy, Engraulis capensis Gilchrist eggs and early larvae by a frontal jet current. J. Conseil Int. Pour L'Exploration Mer 40, 185-198.

Shulze, L.M., Pickart, R.S., 2012. Seasonal variation of upwelling in the Alaskan Beaufort Sea: impact of sea ice cover. J. Geophys. Res.: Oceans 117, C06022.

Siegel, V., 2000. Krill (Euphausiacea) life history and aspects of population dynamics. Can. J. Fish. Aquat. Sci. 57, 130-150.

Siegel, V., Loeb, V., 1995. Recruitment of Antarctic krill Euphausia superba and possible causes for its variability. Mar. Ecol. Prog. Ser. 123, 45-56.

Simmonds, I., 2015. Comparing and contrasting the behaviour of Arctic and Antarctic sea ice over the 35 year period 1979-2013. Ann. Glaciol. 56 (69), 1828.

Siniff, D.B., Garrott, R.A., Rotella, J.J., et al., 2008. Opinion projecting the effects of environmental change on Antarctic seals. Antarct. Sci. 20, 425-435.

Sirenko, B.I., 2009. Main differences in macrobenthos and benthic communities of the Arctic and Antarctic, as illustrated by comparison of the Laptev and Weddell sea faunas. Russ. J. Mar. Biol. 35, 445-453.

Skagseth, Ø., Furevik, T., Ingvaldsen, R., et al., 2008. Volume and heat transports to the Arctic Ocean via the Norwegian and Barents Seas. In: Dickson, R.R., Meincke J., Rhines, P. (Eds.), Arctic-Subarctic Ocean Fluxes, Defining the Role of the Northern Seas in Climate. Springer, Dordrecht, The Netherlands, pp. 45-64.

Slagstad, D., Ellingsen, I.H., Wassmann, P., 2011. Evaluating primary and secondary production in an Arctic Ocean void of summer sea ice: an experimental simulation approach. Prog. Oceanogr. 90, 117-131.

Sloyan, B.M., Rintoul, S.R., 2001. The Southern Ocean limb of the global deep overturning circulation. J. Phys. Oceanogr. 31, 143-173.

Smedsrud, L.H., Esau, I., Ingvaldsen, R.B., et al., 2013. The role of the Barents Sea in the Arctic climate system. Rev. Geophys. 51 (3), 415-449.

Smedsrud, L.H., Ingvaldsen, R., Nilsen, J.E.O., Skagseth, Ø., 2010. Heat in the Barents Sea: transport, storage, and surface fluxes. Ocean Sci. 6, 219-234.

Smith, C.R., DeMaster, D.J., 2008. Preface and brief synthesis for the FOODBANCS volume. Deep-Sea Res. Part II 55, 2399-2403.

Smith, C.R., DeMaster, D.J., Thomas, C., et al., 2012. Pelagic-benthic coupling, food banks, and climate change on the west Antarctic Peninsula Shelf. Oceanography $25,188-201$.

Smith, C.R., Mincks, S.L., DeMaster, D.J., 2006. A synthesis of bentho-pelagic coupling on the Antarctic Shelf: food banks, ecosystem inertia and globa climate change. Deep-Sea Res. Part II 53, 875-894.
Smith, D.A., Hofmann, E.E., Klinck, J.M., Lascara, C.M., 1999. Hydrography and circulation of the West Antarctic Peninsula continental shelf. Deep-Sea Res. Part I 46, 925-949.

Smith, K.L., Robison, B.H., Helly, J.J., et al., 2007. Free-drifting icebergs: hot spots of chemical and biological enrichment in the Weddell Sea. Science 2007, 478-483.

Smith, R.C., Martinson, D.G., Stammerjohn, S.E., et al., 2008. Bellingshausen and western Antarctic Peninsula region: pigment biomass and sea-ice spatial/ temporal distributions and interannual variability. Deep-Sea Res. Part II 55, 1949-1963.

Smith Jr., W.O., Comiso, J.C., 2008. Influence of sea ice on primary production in the Southern Ocean: a satellite perspective. J. Geophys. Res.: Oceans 113. http://dx. doi.org/10.1029/2007jc004251. C05s93.

Smith Jr., W.O., Ainley, D.A., Arrigo, K.R., Dinniman, M.S., 2014b. The oceanography and ecology of the Ross Sea. Annu. Rev. Mar. Sci. 6, 469-487. http://dx.doi.org/ 10.1146/annurev-marine-010213-135114.

Smith Jr., W.O., Ainley, D.G., Cattaneo-Vietti, R., 2007. Trophic interactions within the Ross Sea continental shelf ecosystem. Philos. Trans. R. Soc B: Biol. Sci. 362, 95-111.

Smith Jr., W.O., Dinniman, M.S., Hoffman, E.E., Klinck, J., 2014a. Modeled impacts of changing winds and temperatures on the oceanography of the Ross Sea in the 21st century. Geophys. Res. Lett. 41, 1624-1631. http://dx.doi.org/10.1002/ 2014GL059311.

Smith Jr., W.O., Ainley, D.G., Cattaneo-Vietti, R., Hofmann, E.E., 2012a. The Ross Sea continental shelf: Regional biogeochemical cycles, trophic interactions, and potential future changes. In: Rogers, A.D., Johnston, N.M., Murphy, E.J., Clarke, A. (Eds.), Antarctic Ecosystems: An Extreme Environment in a Changing World, Chapter 7. Blackwell Publishing, London, pp. 213-242.

Smith Jr., W.O., Sedwick, P.N., Arrigo, K.R., et al., 2012b. The Ross Sea in a sea of change. Oceanography 25, 90-103.

Sokolov, S., Rintoul, S.R., 2009a. Circumpolar structure and distribution of the Antarctic Circumpolar Current fronts: 1 . Mean circumpolar paths. J. Geophys. Res.: Oceans 114. http://dx.doi.org/10.1029/2008JC005108.

Sokolov, S., Rintoul, S.R., 2009b. Circumpolar structure and distribution of the Antarctic Circumpolar Current fronts: 2. Variability and relationship to sea surface height. J. Geophys. Res.: Oceans 114. http://dx.doi.org/10.1029/ 2008jc005248.

Solomon, S.D., Ivy, J., Kinnison, D., et al., 2016. Emergence of healing in the Antarctic ozone layer. Science. http://dx.doi.org/10.1126/science.aae0061.

Solomon, S., Qin, D., Manning, M., et al., 2007. Technical summary. In: Solomon, S., Qin, D., Manning, M., Chen, Z., Marquis, M., Averyt, K.B., Tignor, M., Miller, H.L. (Eds.), Climate Change 2007: The Physical Science Basis. Contribution of Working Group I to the Fourth Assessment Report of the Intergovernmental Panel on Climate Change. Cambridge University Press, Cambridge, United Kingdom and New York, NY, USA, pp. 19-92.

Søreide, J.E., Leu, E., Berge, J., Graeve, M., Falk-Petersen, S., 2010. Timing in blooms, algal food quality and Calanus glacialis reproduction and growth in a changing Arctic. Glob. Change Biol. 16, 3154-3163.

Sorteberg, A., Kvingedal, B., 2006. Atmospheric forcing on the Barents Sea winter ice extent. J. Clim. 19, 4772-4784.

Southwell, C.J., Kerry, K.R., Ensor, P.H., 2005. Predicting the distribution of crabeater seals Lobodon carcinophaga off east Antarctica during the breeding season. Mar. Ecol. Prog. Ser. 299, 297-309.

Springer, A.M., McRoy, C.P., Flint, M.V., 1996. The Bering Sea Green Belt: shelf-edge processes and ecosystem production. Fish. Oceanogr. 5, 205-223.

Springer, A.M., McRoy, C.P., Turco, K.R., 1989. The paradox of pelagic food webs in the northern Bering Sea-II. Zooplankton communities. Cont. Shelf Res. 9, 359386.

Stabeno, P.J., Bond, N.A., Kachel, N.B., et al., 2001. On the temporal variability of the physical environment over the south-eastern Bering Sea. Fish. Oceanogr. 10, $81-98$.

Stabeno, P.J., Farley Jr., E.V., Kachel, N.B., et al., 2012. A comparison of the physics of the northern and southern shelves of the eastern Bering Sea and some implications for the ecosystem. Deep-Sea Res. Part II 65-70, 14-30.

Stammerjohn, S.E., Martinson, D.G., Smith, R.C., Iannuzzi, R.A., 2008a. Sea ice in the western Antarctic Peninsula region: spatio-temporal variability from ecological and climate change perspectives. Deep-Sea Res. Part II 55, 2041 2058.

Stammerjohn, S.E., Martinson, D.G., Smith, R.C., et al., 2008b. Trends in Antarctic annual sea ice retreat and advance and their relation to El Nino-Southern Oscillation and Southern Annular Mode variability. J. Geophys. Res. 113, C03S90. http://dx.doi.org/10.1029/2007JC004269.

Starmans, A., Gutt, J., 2002. Mega-epibenthic diversity: a polar comparison. Mar. Ecol. Prog. Ser. 225, 45-52.

Steele, M., Ermold, W., Zhang, J., 2007. Arctic Ocean surface warming trends over the 20th century. AGU Fall Meeting Abstracts, vol. 1, p. 01

Stern, A.A., Johnson, E., Holland, D.M., et al., 2015. Wind-driven upwelling around grounded tabular icebergs. J. Geophys. Res.: Oceans 120, 5820-5835. http://dx. doi.org/10.1002/2015JC010805.

Stigebrandt, A., 1984. The North Pacific: a global-scale estuary. J. Phys. Oceanogr. 14, 464-470.

Stirling, I., 1997. The importance of polynyas, ice edges, and leads to marine mammals and birds. J. Mar. Syst. 10, 9-21.

Storr-Paulsen, M., Wieland, K., Hovgård, H., Rätz, H.-J., 2004. Stock structure of Atlantic cod (Gadus morhua) in West Greenland waters: implications of transport and origin. ICES J. Mar. Sci. 61, 972-982. 
Stroeve, J.C., Markus, T., Boisvert, L., et al., 2014. Changes in Arctic melt season and implications for sea ice loss. Geophys. Res. Lett. http://dx.doi.org/10.1029/ 2013 GL058951.

Stroeve, J.C., Serreze, M.C., Holland, M.M., et al., 2012. The Arctic's rapidly shrinking sea ice cover: a research synthesis. Clim. Change 110, 1005-1027.

Sundby, S., Drinkwater, K., 2007. On the mechanisms behind salinity anomaly signals of the northern North Atlantic. Prog. Oceanogr. 73, 190-202.

Sundby, S., Drinkwater, K.F., Kjesbu, O., 2016. The North Atlantic spring-bloom system - where the changing climate meets the winter dark. Front. Mar. Sci. 28. http://dx.doi.org/10.3389/fmars.2016.00028.

Svetividov, A.N., 1948. Fauna SSSR. Ryby 9 (4). Treskoobraznye (Fauna of the U.S.S.R. Fishes 9 (4), Gadiformes). Zoologicheskii Institut Akademii Nauk SSSR 34. (Israel Program for Scientific Translations, Jerusalem, 1962). Boreogadus saida (Lepechin) - Polar Cod, Saika, pp. 210-214.

Tamelander, T., Renaud, P.E., Hop, H., et al., 2006. Trophic relationships and pelagicbenthic coupling during summer in the Barents Sea Marginal Ice Zone, revealed by stable carbon and nitrogen isotope measurements. Mar. Ecol. Prog. Ser. 310, 33-46.

Tande, K.S., Hassel, A., Slagstad, D., 1985. Gonad maturation and possible life cycle strategies in Calanus finmarchicus and Calanus glacialis in the northwestern part of Barents Sea. In: Gray, J.S., Christiansen, M.E. (Eds.), 18th European Marine Biology Symposium, Oslo, 1985. John Wiley and Sons Ltd., New York, pp. 141155.

Tarling, G.A., Cuzin-Roudy, J., Thorpe, S.E., et al., 2007. Recruitment of Antarctic krill Euphausia superba in the South Georgia region: adult fecundity and the fate of larvae. Mar. Ecol. - Prog. Ser. 331, 161-179.

Tchernia, P., Jeannin, P.F., 1980. Observations on the Antarctic East Wind Drift using tabular icebergs tracked by satellite Nimbus F (1975-1977). Deep-Sea Res. Part I 27, 467-474.

Thatje, S., Fuentes, V., 2003. First record of anomuran and brachyuran larvae (Crustacea: Decapoda) from Antarctic waters. Polar Biol. 26, 279-282.

Thatje, S., Hillenbrand, C.-D., Mackensen, A., Larter, R., 2008. Life hung by a thread: endurance of Antarctic fauna in glacial periods. Ecology 89, 682-692.

Thiele, D., Gill, P.C., 1999. Cetacean observations during a winter voyage into Antarctic sea ice south of Australia. Antarct. Sci. 11, 48-53.

Thiele, D., Chester, E.T., Gill, P.C., 2000. Cetacean distribution off eastern Antarctica $\left(80-150^{\circ} \mathrm{E}\right)$ during the Austral summer of 1995/1996. Deep-Sea Res. II 47, 2543-2572.

Thomas, E., Booth, L., Maslin, M., Shackleton, N.J., 1995. Northeastern Atlantic benthic foraminifera during the last 45,000 years: changes in productivity seen from the bottom up. Paleoceanography 10, 545-562.

Thompson, D.W.J., Solomon, S., 2002. Interpretation of recent Southern Hemisphere climate change. Science 296, 895-899.

Thompson, D.W.J., Wallace, J.M., 1998. The Arctic Oscillation signature in the wintertime geopotential height and temperature fields. Geophys. Res. Lett. 25, 1297-1300.

Thompson, D.W.J., Solomon, S., Kushner, P.J., et al., 2011. Signatures of the Antarctic ozone hole in Southern Hemisphere surface climate change. Nat. Geosci. 4, 741749.

Thorpe, S.E., Heywood, K.J., Stevens, D.P., Brandon, M.A., 2004. Tracking passive drifters in a high resolution ocean model: implications for interannual variability of larval krill transport to South Georgia. Deep-Sea Res. Part I 51, 909-920.

Thorpe, S.E., Murphy, E.J., Watkins, J.L., 2007. Circumpolar connections between Antarctic krill (Euphausia superba Dana) populations: investigating the roles of ocean and sea ice transport. Deep-Sea Res. Part I 54, 792-810.

Thrush, S., Dayton, P., Cattaneo-Vietti, R., et al., 2006. Broad-scale factors influencing the biodiversity of coastal benthic communities of the Ross Sea. Deep-Sea Res. Part II 53, 959-971.

Trathan, P.N., Bishop, C., Maclean, G., et al., 2008. Linear tracks and restricted temperature ranges characterise penguin foraging pathways. Mar. Ecol. Prog. Ser. 370, 285-294.

Trathan, P.N., Everson, I., Murphy, E.J., Parkes, G.B., 1998. Analysis of haul data from the South Georgia krill fishery. CCAMLR Sci. 5, 9-30.

Trathan, P.N., Forcada, J., Murphy, E.J., 2007. Environmental Forcing and Southern Ocean marine predator populations: effects of climate change and variability. Philos. Trans. R. Soc. 362, 2351-2365.

Trathan, P.N., Fretwell, P.T., Stonehouse, B., 2011. First recorded loss of an Emperor Penguin colony in the recent period of Antarctic regional warming: implications for other colonies. PLoS ONE 6, e14738. http://dx.doi.org/10.1371/journal. pone.0014738.

Trathan, P.N., Murphy, E.J., Forcada, J., et al., 2006. Physical forcing in the southwest Atlantic: ecosystem control. In: Boyd, I.L., Wanless, S., Camphuysen, K. (Eds.), Top Predators in Marine Ecosystems: Their Role in Monitoring and Management. Cambridge University Press, Cambridge, UK, pp. 28-45.

Tremblay, J.-É., Smith Jr., W.O., 2007. Phytoplankton processes in polynyas. In: Smith, W.O., Jr., Barber, D.G. (Eds.), Polynyas: Windows to the World's Oceans. Elsevier, Amsterdam, pp. 239-270.

Tremblay, J.-É., Anderson, L.G., Matrai, P., et al., 2015. Global and regional drivers of nutrient supply, primary production and $\mathrm{CO}_{2}$ drawdown in the changing Arctic Ocean. Prog. Oceanogr. 139, 171-196.

Tremblay, J.-É., Hattori, H., Michel, C., et al., 2006a. Trophic structure and pathways of biogenic carbon flow in the eastern North Water Polynya. Prog. Oceanogr. 71, 402-425.

Tremblay, J.-É., Michel, C., Hobson, K.A., et al., 2006b. Bloom dynamics in early opening waters of the Arctic Ocean. Limnol. Oceanogr. 51, 900-912.
Trenberth, K.E., Caron, J.M., 2001. Estimates of meridional atmosphere and ocean heat transports. J. Clim. 14, 3433-3443.

Trivelpiece, W.Z., Fraser, W.R., 1995. The breeding biology and distribution of Adélie penguins' adaptations to environmental variability. Antarct. Res. Ser. 70, $273-$ 285.

Turner, J., 2004. The El-Nino-southern oscillation and Antarctica. Int. J. Climatol. 24 1-31. http://dx.doi.org/10.1002/joc.965.

Turner, J., Marshall, G.J., 2011. Climate Change in the Polar Regions. Cambridge University Press, Cambridge. 448 pp.

Turner, J., Overland, J., 2009. Contrasting climate change in the two polar regions. Polar Res. 28 (146), 164.

Turner, J., Colwell, S.R., Marshall, G.J., et al., 2005a. Antarctic climate change during the last 50 years. Int. J. Climatol. 25, 279-294.

Turner, J., Comiso, J.C., Marshall, G.J., et al., 2009. Non-annular atmospheric circulation change induced by stratospheric ozone depletion and its role in the recent increase of Antarctic sea ice extent. Geophys. Res. Lett. 36. http://dx. doi.org/10.1029/2009gl037524.

Turner, J., Hosking, J.S., Bracegirdle, et al., 2015. Recent changes in Antarctic Sea Ice Philos. Trans. R. Soc. A: Math. Phys. Eng. Sci. 373 (2045). http://dx.doi.org/ 10.1098/rsta.2014.0163.

Turner, J., Lachlan-Cope, T., Colwel, I.S., Marshall, G.J., 2005b. A positive trend in western Antarctic Peninsula precipitation over the last 50 years reflecting regional and Antarctic-wide atmospheric circulation changes. Ann. Glaciol. 41, 85-91.

Tynan, C.T., 1998. Ecological importance of the Southern Boundary of the Antarctic Circumpolar Current. Nature 392, 708-710. http://dx.doi.org/10.1038/33675.

Ugryumov, A., Korovin, V., 2005. TIGU-SU. På isflak mot Nordpolen. In: Dahle, S. Jensen, F.A., Falk-Petersen, D. (Eds.), Forlaget Nord, Svolvær, Norway.

Vacchi, M., DeVries, A.L., Evans, C.W., et al., 2012. A nursery area for the Antarctic silverfish Pleuragramma antarcticum at Terra Nova Bay (Ross Sea): first estimate of distribution and abundance of eggs and larvae under the seasonal sea-ice. Polar Biol. 35, 1573-1585. http://dx.doi.org/10.1007/s00300-012-1199-y.

Varpe, O., 2012. Fitness and phenology: annual routines and zooplankton adaptations to seasonal cycles. J. Plankton Res. 34, 267-276.

Veit, R.R., Hunt Jr., G.L., 1992. The spatial dispersion of seabirds near the South Orkney Islands and the Weddell-Scotia confluence. Polar Biol. 11, 637-641.

Vermeij, G.J., 1991. Anatomy of an invasion: the trans-Arctic interchange. Paleobiology 17, 281-307.

Vestfals, C.D., Ciannelli, L., Duffy-Anderson, J.T., Ladd, C., 2014. Effects of seasonal and interannual variability in along-shelf and cross-shelf transport on groundfish recruitment in the eastern Bering Sea. Deep-Sea Res. Part II 109 190-203.

Vikebø, F.B., Husebø, Å., Slotte, A., et al., 2010. Effect of hatching date, vertical distribution, and interannual variation in physical forcing on northward displacement and temperature conditions of Norwegian spring-spawning herring larvae. ICES J. Mar. Sci. 67, 1948-1956.

Vinje, T., 2001. Fram Strait ice fluxes and atmospheric circulation: 1950-2000. J. Clim. 14, 3508-3517.

Visser, I.N., Smith, T.G., Bullock, I.D., et al., 2008. Antarctic peninsula killer whales (Orcinus orca) hunt seals and a penguin on floating ice. Mar. Mammal Sci. 24, 225-234.

von Bodungen, B., Smetacek, V., Tilzer, M.M., Zeitzschel, B., 1986. Primary production and sedimentation during spring in the Antarctic Peninsula region. Deep-Sea Res. Part I 33, 177-194.

Walkusz, W., Kwasniewski, S., Dmoch, K., et al., 2004. Characteristics of the Arctic and Antarctic mesozooplankton in the neritic zone during summer. Pol. Polar Res. 25, 275-291.

Walsh, J.E., 2014. Intensified warming of the Arctic: causes and impacts on middle latitudes. Glob. Planet. Change 117, 52-63.

Walsh, J.E., Overland, J.E., Groisman, P.Y., Rudolf, B., 2011. Ongoing climate change in the Arctic. Ambio 40, 6-16.

Walsh, J.J., McRoy, C.P., Coachman, L.K., et al., 1989. Carbon and nitrogen cycling within the Bering/Chukchi Seas: source regions for organic matter effecting AOU demands of the Arctic Ocean. Prog. Oceanogr. 22, 277-359.

Wang, M., Overland, J.E., 2015. Projected future duration of the sea-ice-free season in the Alaskan Arctic. Prog. Oceanogr. 136, 50-59.

Ward, P., Whitehouse, M., Shreeve, R., et al., 2007. Plankton community structure south and west of South Georgia (Southern Ocean): links with production and physical forcing. Deep-Sea Res. Part I 54, 1871-1889.

Wassmann, P., Kosobokova, K.N., Slagstad, D., et al., 2015. The contiguous domains of Arctic Ocean advection: trails of life and death. Prog. Oceanogr. 139 42-65.

Wassmann, P., Reigstad, M., Haug, T., et al., 2006. Food webs and carbon flux in the Barents Sea. Prog. Oceanogr. 71, 232-287.

Watanabe, E., Kishi, M.J., Ishida, A., Aita, M.N., 2012. Western Arctic primary productivity regulated by shelf-break warm eddies. J. Oceanogr. 68, 703-718.

Wefer, G., Fischer, G., 1991. Annual primary production and export flux in the Southern Ocean from sediment trap data. Mar. Chem. 35, 597-613.

Weimerskirch, H., Guionnet, T., Martin, J., et al., 2000. Fast and fuel efficient? Optimal use of wind by flying albatrosses. Proc. R. Soc. B: Biol. Sci. 267, 18691874.

Weimerskirch, H., Louzao, M., de Grissac, S., Delord, K., 2012. Changes in wind pattern alter albatross distribution and life-history traits. Science 335, 211-214.

Weimerskirch, H., Salamolard, M., Sarrazin, F., Jouventin, P., 1993. Foraging strategy of wandering albatrosses through the breeding season: a study using satellite telemetry. Auk 110, 325-342. 
Weingartner, T., Aagaard, K., Woodgate, R., et al., 2005. Circulation on the north central Chukchi Sea shelf. Deep-Sea Res. Part II 52, 3150-3174.

Werner, I., Auel, H., Garrity, C., Hagen, W., 1999. Pelagic occurence of the sympagic amphipod Gammarus wilkitzkii in ice-free waters of the Greenland Sea - dead end or part of life-cycle? Polar Biol. 22, 56-60.

Weslawski, J.M., Legezynska, J., 2002. Life cycles of some Arctic amphipods. Pol. Polar Res. 23, 253-264.

Whitehouse, M.J., Meredith, M.P., Rothery, P., et al., 2008. Rapid warming of the ocean around South Georgia, Southern Ocean, during the 20th century: forcings, characteristics and implications for lower trophic levels. Deep-Sea Res. Part I 55, 1218-1228.

Wiedenmann, J. Cresswell, K.A., Goldbogen, J., et al, 2011, Exploring the effects of reductions in krill biomass in the Southern Ocean on blue whales using a statedependent foraging model. Ecol. Model. 222, 3366-3379.

Wiedenmann, J., Cresswell, K.A., Mangel, M., 2009. Connecting krill recruitment and sea ice. Limnol. Oceanogr. 54, 799-811.

Wiig, Ø., Born, E.W., Toudal Pedersen, L., 2003. Movement of female polar bears (Ursus maritimus) in the East Greenland pack ice. Polar Biol. 26, 509-516.

Wilderbuer, T.K., Hollowed, A.B., Ingraham Jr., W.J., et al., 2002. Flatfish recruitment response to decadal climatic variability and ocean conditions in the eastern Bering Sea. Prog. Oceanogr. 55, 235-247.

Wilderbuer, T., Stockhausen, W., Bond, N., 2013. Updated analysis of flatfish recruitment response to climate variability and ocean conditions in the Eastern Bering Sea. Deep-Sea Res. Part II 94, 157-164.

Williams, G.D., Nicol, S., Aoki, S., et al., 2010. Surface oceanography of BROKE-West, along the Antarctic margin of the south-west Indian Ocean (30-80 ${ }^{\circ}$ ). Deep-Sea Res. Part II 57, 738-757.

Wood, K.R., Overland, J.E., Salo, S.A., et al., 2013. Is there a "new normal" climate in the Beaufort Sea? Polar Res. 32. UNSP 19552.

Woodgate, R.A., Aagaard, K., 2005. Revising the Bering Strait freshwater flux into the Arctic Ocean. Geophys. Res. Lett. 32, L02602. http://dx.doi.org/10.1029/ 2004 GL021747.

Woodgate, R.A. Aagaard, K. Weingartner, T. 2005a. A year in the physical oceanography of the Chukchi Sea: moored measurements from autumn 19901991. Deep-Sea Res. Part II 52, 3116-3149. http://dx.doi.org/10.1016/j. dsr2.2005.10.016.
Woodgate, R.A., Aagaard, K., Weingartner, T.J., 2005b. Monthly temperature salinity, and transport variability of the Bering Strait throughflow. Geophys. Res. Lett. 32 L04601. http://dx.doi.org/10.1029/2004GL021880.

Woodgate, R.A., Stafford, K.M., Prahl, F.G., 2015. A synthesis of year-round interdisciplinary mooring measurements in the Bering Strait (1990-2014) and the RUSALCA years (2004-2011). Oceanography 28 (3), 46-67.

Woodgate, R.A., Weingartner, T.J., Lindsay, R., 2012. Observed increases in Bering Strait oceanic fluxes from the Pacific to the Arctic from 2001 to 2011 and their impacts on the Arctic Ocean water column. J. Geophys. Res. 39, L24603. http:// dx.doi.org/10.1029/2012GLo54092.

Yao, T., Tang, C.L., 2003. The formation and maintenance of the North Water Polynya. Atmos. Ocean 41, 187-201.

Yin, J., Griffies, S.M., Stouffer, R.J., 2010. Spatial variability of sea level rise in twentyfirst century projections. J. Clim. 23, 4585-4607.

Young, E.F., Rock, J., Meredith, M.P., et al., 2012. Physical and behavioural influences on larval fish retention: contrasting patterns in two Antarctic fishes. Mar. Ecol. Prog. Ser. 465, 201-215. http://dx.doi.org/10.3354/meps09908.

Young, E.F., Belchier, M., Hauser, L., et al., 2015. Oceanography and life history predict contrasting genetic population structure in two Antarctic fish species. Evol. Appl. 8, 486-505. http://dx.doi.org/10.1111/eva.12259.

Young, E.F., Thorpe, S.E., Banglawala, N., Murphy, E.J., 2014. Variability in transport pathways on and around South Georgia shelf, Southern Ocean: implications for recruitment and retention. J. Geophys. Res. 119, 241-252. http://dx.doi.org/ 10.1002/2013JC009348.

Younger, J.L., Emmerson, L.M., Miller, K.J., 2016. The influence of historical climate changes on Southern Ocean marine predator populations: a comparative analysis. Glob. Change Biol. 22, 474-493.

Yu, J.-Y., Paek, H., Saltzman, E.S., Lee, T., 2015. The early 1990s change in ENSO-PSASAM relationships and its impact on Southern Hemisphere climate. J. Clim. 28 (23), 9393-9408. http://dx.doi.org/10.1175/jcli-d-15-0335.1.

Yuan, X.J., Martinson, D.G., 2001. The Antarctic Dipole and its predictability. Geophys. Res. Lett. 28 (18), 3609-3612. http://dx.doi.org/10.1029/ 2001 gl012969.

Zacher, K., Rautenberger, R., Hanelt, D., et al., 2009. The abiotic environment of polar marine benthic algae. Bot. Mar. 52, 483-490. 